\title{
A Northern Experience
}

\author{
By \\ Julie Manon Savignac \\ B. Arch Studies
}

\begin{abstract}
A thesis submitted to
In Fulfillment of

The requirements for the degree of

Master of Architecture

School of Architecture

Carleton University

Ottawa, Ontario

May 2005

(c) 2005 Julie Savignac
\end{abstract}

The Faculty of Graduate Studies and Research 
Library and

Archives Canada

Published Heritage Branch

395 Wellington Street Ottawa ON K1A 0N4 Canada
Bibliothèque et

Archives Canada

Direction du

Patrimoine de l'édition

395 , rue Wellington

Ottawa ON K1A ON4

Canada

\section{NOTICE:}

The author has granted a nonexclusive license allowing Library and Archives Canada to reproduce, publish, archive, preserve, conserve, communicate to the public by telecommunication or on the Internet, loan, distribute and sell theses worldwide, for commercial or noncommercial purposes, in microform, paper, electronic and/or any other formats.

The author retains copyright ownership and moral rights in this thesis. Neither the thesis nor substantial extracts from it may be printed or otherwise reproduced without the author's permission.
AVIS:

L'auteur a accordé une licence non exclusive permettant à la Bibliothèque et Archives Canada de reproduire, publier, archiver, sauvegarder, conserver, transmettre au public par télécommunication ou par l'Internet, prêter, distribuer et vendre des thèses partout dans le monde, à des fins commerciales ou autres, sur support microforme, papier, électronique et/ou autres formats.

L'auteur conserve la propriété du droit d'auteur et des droits moraux qui protège cette thèse. $\mathrm{Ni}$ la thèse ni des extraits substantiels de celle-ci ne doivent être imprimés ou autrement reproduits sans son autorisation.
In compliance with the Canadian Privacy Act some supporting forms may have been removed from this thesis.

While these forms may be included in the document page count, their removal does not represent any loss of content from the thesis.
Conformément à la loi canadienne sur la protection de la vie privée, quelques formulaires secondaires ont été enlevés de cette thèse.

Bien que ces formulaires aient inclus dans la pagination, il n'y aura aucun contenu manquant.

\section{Canadà}




\begin{abstract}
A Northern Experience

From the Atlantic to the Pacific, from the North to South Canada houses a multitude of diversities with its people, environment, culture and tradition. The question then arises, why are most contemporary houses characteristically built the same, following only one style or architectural language? Although site conditions vary greatly across the country, little recognition of these changes is evident within the buildings themselves. The house is no longer reflective of regional traditions or cultures. Rather than evaluating a house on its architectural response to site or ingenuity, the general public will assess it based on its economical value and its integration within preconceived norms.

Advances in technology and building methods have allowed for duplicate buildings to be erected in different environmental conditions. However, this should not become the determining factor in the construction method. Rather than ignoring the landscape surrounding a building, it should be integrated and adapted construction-wise allowing architecture and nature to be combined in a harmonious way. Has the balance between preconceived building processes and an environmental based architecture been pulled out of sync by an overconsumption of a singular typology?
\end{abstract}




\section{Acknowledgments}

A large number of people have contributed to this thesis and for their help they should be acknowledged. Many thanks to all the farmers and citizens of Verner who allowed me to visit their farmsteads. I thank them for taking the time to inform and teach me about their lives and those of their ancestors.

I thank my thesis advisor Sheryl Boyle for keeping me on track and for her constant encouragement.

A special thanks should be given to Critchley Delean Trussler Evans Bertrand Architects Inc. for supporting me during my studies by allowing me to work part-time and utilizing their facilities. Their positive insight and encouragement was greatly appreciated.

I thank Jan Pretty for encouraging me to continue and taking time out of her busy schedule to edit my text throughout the entire process.

A final thanks to my family and husband Cory for his support and encouragement during my six years of university. 


\section{Table of Contents}

\section{A Northern Experience}

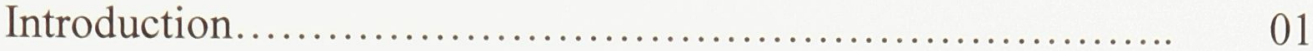

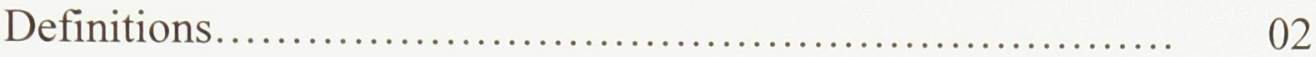

Ephemeral Structures..................................... 04

A Selection of Past Traditions/Methods of Construction in Canada 10

Preconceived Notions....................................... 14

History of Verner........................................ 15

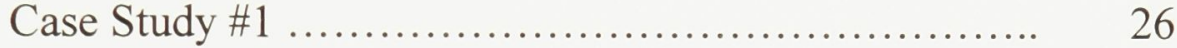

Case Study \#2 ................................... 33

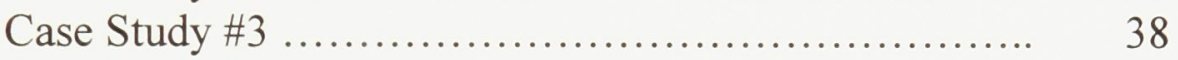

Case Study \#4 ....................................... 39

The Importance of a New Approach....................... 42

An Examination of Design Practices ............................ 44

Design Project ........................................... 53

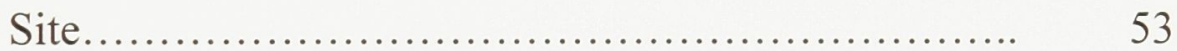

Modes of Investigations............................ 55

Responses........................................ 72

Final Project..................................... 77

Conclusion.............................................. 88 


\section{List of Tables}

Table 1 - $\quad$ Matrix of case studies by Julie Savignac

Table 2- Matrix of final project by Julie Savignac 


\section{List of Illustrations}

Unless otherwise stated all figures are either photographs, diagrams, or drawings by the author.

Figure 1 - Typical home found on the market

Figure 2 - Duck blind

Figure 3 - Bird's nest

Figure 4 - Tree house

Figure 5 - $\quad$ Train bridge located in Sturgeon Falls, Ontario

Figure 6 - Science North, Sudbury, Ontario

Figure 7 - Igloo - Pierre Thibault, Projects and Achievements (Québec:

Belle Publisher, 1997) 31.

Figure 8 - view of Main Street, Verner, Ontario

Figure 9 - Caldwell Township divisions - Gérald Beaudry, et al. Verner: cent ans d'histoire à raconter. . (Verner: Bureau du canton de Caldwell, 1995) 34.

Figure 10 - Co-operative granary mill, Verner, Ontario

Figure 11 - The Paquette Farm, Verner, Ontario

Figure 12- Cross sectional of the Paquette house

Figure 13 - Plan of the Paquette house

Figure 14- The barn's hayloft

Figure 15 - The barn's roof members

Figure 16 - Wood shavings within the barn walls

Figure 17- Barn built into the hillside

Figure 18- Cross section of the barn

Figure 19- Cross section of the barn

Figure 20- The Leclair Farm, Verner

Figure 21- Floor joist poured into a foundation wall

Figure 22 The Veuve River, with the Leclair Farm in the background

Figure 23- A Joint detail found within the barn

Figure 24- Barn members

Figure 25 - A built up beam

Figure 26 - Granary, Verner, Ontario

Figure 27 - Granary

Figure 28 - Icehouse

Figure 29 - Winter Gardens - N.A. "Winter Gardens," Canadian Architect 46.12 (2001): 30-31.

Figure 30 - Winter Gardens - N.A. "Winter Gardens," Canadian Architect 46.12 (2001): 30-31.

Figure 31 - Advanced Training Centre - Documents in Canadian Architecture, Barry Johns Architects (Halifax: Tuns Press, 2000) 20.

Figure 32 - Cross Section of the Advanced Training Centre -Documents in Canadian Architecture, Barry Johns Architects (Halifax: Tuns Press, 2000) 26. 
Figure 33- $\quad$ Site Plan, Science North - George Thomas Kapelos, Interpretations of Nature: Contemporary Canadian Architecture, Landscape and Urbanism (Kleinburg: McMichael Canadian Art Collection, 1994) 65.

Figure 34 - Science North, Sudbury, Ontario

Figure 35 - $\quad$ Bridge on Ramsey Lake, Science North, Sudbury, Ontario

Figure 36- Bridge on Ramsey Lake, Science North, Sudbury, Ontario

Figure 37- Aerial view of Verner; obtained from the government of Ontario

Figure 38- Village of Verner; obtained from the municipality of West

Nipissing

Figure 39- Sketch

Figure 40- Sketch

Figure 41- Map of Verner; obtained from the Ministry of Energy, Mines and Resources Canada (overlay drawn by Julie Savignac)

Figure 42- $\quad$ Map of Verner; obtained from the Ministry of Energy, Mines and Resources Canada (overlay drawn by Julie Savignac)

Figure 43- Map demonstrating municipal water patterns; obtained from the municipality of West Nipissing

Figure 44- Diagram

Figure 45- Diagram

Figure 46- Sun chart; Stein Reynolds, Mechanical and Electrical Equipment for Buildings, $9^{\text {th }}$ ed., (New York: John Wiley \& Sons, Inc., 2000) 88.

Figure 47- Model

Figure 48- Photographs

Figure 49- Installation

Figure 50- Installation

Figure 51- Installation

Figure 52- Installation

Figure 53- Installation

Figure 54- Installation

Figure 55- Installation

Figure 56- Installation

Figure 57- Sketch

Figure 58- Sketch

Figure 59- Sketch

Figure 60- Sketch

Figure 61- Sketch

Figure 62- Sketch

Figure 63- Models

Figure 64- Diagram

Figure 65- Diagram

Figure 66- Diagram

Figure 67- Diagram

Figure 68- Kit of parts

Figure 69- Plan of the first scheme 
Figure 70- Plan

Figure 71- Cross section of the first scheme

Figure 72- Plan of the second scheme

Figure 73- Plan

Figure 74- Cross section of the second scheme 
My country is not a country, it's the winter

My garden is not a garden, it's the plain

My road is not a road, it's the snow. . .

Gille Vigneault

MON PAYS

\section{A Northern Experience}

From the Atlantic to the Pacific, from the North to South Canada houses a multitude of diversities with its people, environment, culture and tradition. The question then arises, why are most contemporary houses characteristically built the same, following only one style or architectural language? Although site conditions vary greatly across the country, little recognition of these changes is evident within the buildings themselves. The house is no longer reflective of regional traditions or cultures. Rather than evaluating a house on its architectural response to site or ingenuity, the general public will assess it based on its economical value and its integration within preconceived norms. For instance, a house with a double garage, typical in a suburban setting is valued over the farmhouse. Closer examination of the farmhouse, however, reveals a specialized type of living. Not only does the farmhouse provide shelter, it is designed around a set of principles aimed at selfsufficiency and utmost integration with the surroundings.

Advances in technology and building methods have allowed for duplicate buildings to be erected in different environmental conditions. However, this should not become the determinate factor in the construction method. Rather than ignoring the landscape surrounding a building, it should be integrated and adapted construction-wise allowing architecture and nature to combine in a harmonious way. Has the balance between preconceived building processes and an environmental 
based architecture been pulled out of sync by an over-consumption of a singular typology?

Established preconceived norms of Canadian architecture have produced a new form of architecture which is based on foreign models and speaks very little of this country. In order to obtain a better understanding of these preconceived norms and how they became socially accepted, one needs to examine the history of Canadian domestic architecture. While this history will be examined on a general level, a more specific look at the question will be explored by examining the small rural community of Verner, Ontario. A strong sense of tradition and culture can be found in this community, components, which are rarely embodied in newly erected houses. That is not to say that all new architecture in this community is terrible, but rather that the presence of a clear vernacular language is being driven by popular trends and ideals, erasing what knowledge is embedded and proven in the previous building types.

To further this research, a number of prominent architects will be examined to determine how they deal with the issues of tradition, innovation, and integration of a building within the environmental context. The purpose of this research is to redefine society's general conception of houses and make a proposition, which might appear unconventional at first glance, but offers a greater versatility and integration with the surroundings. Finally, an experimental architectural project will be conducted and discussed in direct response to this research. 


\section{Definitions}

Before entering into the discussion, certain key words should be defined.

Throughout this paper, the word technology is often employed. Raymond Williams, author of Keywords: A Vocabulary Of Culture And Society defines technology as follows:

"It was mainly in mC19 [middle period of the
nineteenth century] that technology became fully
specialized to the 'practical arts'; this is also the period
of technologist. The newly specialized sense of
SCIENCE (q.v.) and scientist opened the way to a
familiar modern distinction between knowledge
(science) and its practical application (technology),
within the selected field. This leads to some
awkwardness as between technical - matters of
practical construction - and technological - often used
in the same sense, but with the residual sense (in logy)
or systematic treatment. In fact there is still room for a
distinction between the two words, with technique as a
particular construction or method, and technology as a
system of such means and methods;"'

Since the word technology has various references, for the purpose of this exercise it should be understood in the context that Williams defines technique: as a particular construction method, or process. The word technology will also be utilized to express new advancements in certain fields: i.e. building materials and systems.

A second term deserving attention is the word nature. Tomas Kapelos, author of Interpretations of Nature; Contemporary, Canadian, Architecture,

Landscape and Urbanism, discusses the word nature in terms of Williams definition, followed by his own critique.

"Nature, he [Raymond Williams] says, can be defined as 'the material world itself, taken as including human

\footnotetext{
${ }^{1}$ Raymond Williams, Keywords: A Vocabulary Of Culture And Society, Rev. ed. (New
} York: Oxford University Press, 1983) 315. 
beings.' [emphasis added by Kapelos] Such a take-itor-leave it attitude does not reconcile us with those events and conditions which affect our existence and are beyond our control. Where do frostbite, blizzards, fogs and mosquitoes, or hunger, disease and death, fit in? Could it be that nature is something that we can choose to ignore when we want to, or more significantly, can define to suit our purposes?"2

Kapelos' comment on Williams' definition clearly demonstrates the complexity of the word. But for the purpose of this discussion, the word 'nature' will be utilized to express nature with intervention. 'Natural environment' will refer to nature without intervention.

\section{Ephemeral Structures}

Rural environments are deeply embedded with culture and tradition, but these are gradually being replaced with preconceived notions of the ideal, hence an architecture which speaks more about homogeneity than individuality. Jorma Mänty and Norman Pressman, authors of Cities Designed For Winter state: "New environments and built-up [suburban] areas are without true traditional genius loci. Our spaces are deprived, monotonous. We exploit natural resources without any idea as to their qualified use and care. We have broken the consensus between man and nature; we believe in absolute change and the idea of genius loci is completely excluded."3 Harold Strub author of Bare Poles: Building Design For High Latitudes strengthens the argument by adding:

"Our basic expectations (shelter, power) exclude anything that makes sense in the larger picture. We

${ }^{2}$ George Thomas Kapelos, Interpretations of Nature; Contemporary, Canadian, Architecture, Landscape and Urbanism (Kleinburg: McMichael Canadian Art Collection, 1994) 14.

${ }^{3}$ Jorma Mänty and Norman Pressman, ed., Cities Designed For Winter (Helsinki: Building Book Ltd, 1988) 14. 
find this acceptable in buildings, because humans excel at adapting to new environments no matter how inefficient, uncomfortable, or joyless they may be. Instead of moulding the building to fit our identities, to have it reinforce and improve our ways of life, we allow the building to mould us."

Strub's comment with regards to buildings rings true in the suburban home. Models, like the suburban house (Fig. 1), are threatening the special characteristics of dwellings found in Northern

Ontario, and it is those characteristics that this research intends to discover and retain.

The first steps in this discovery

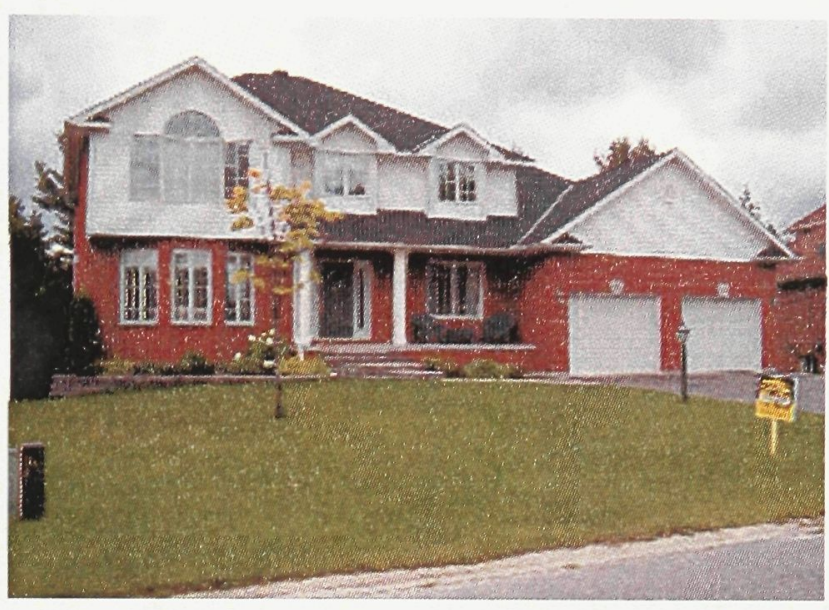

Figure 1 - Typical home found on the market

process began with the establishment of good architectural examples, which engaged the natural environment found in Northern Ontario. The area of study was limited to the municipality of West Nipissing and its surrounding cities, such as Sudbury, for definition and time. The goal was to find examples that demonstrated a strong relationship to the environment as well as local traditions and cultures.

The first examples studied were mainly ephemeral structures both man-made and natural. These consisted of a bird's nest, a tree house, a beaver's lodge, and a duck blind. Other more permanent structures that were observed were a steel train bridge, a log house, various barns, and the Science North building in Sudbury. What was discovered during these observations were innovative ways of integrating structures within the environment. For example, the duck blind (Fig. 2) is set on

\footnotetext{
${ }^{4}$ Harold Strub, Bare Poles: Building Design For High Latitudes (Ottawa: Carleton
} University Press, 1996) 71. 
pilotis floating over the water and defines a clear sense of horizon from within. Its construction consists of readily available materials such as small trees, leaves, and weeds. The structure is designed to provide the hunter with a dry area, concealed from waterfowl flying overhead. Once the hunting season is finished, the structure

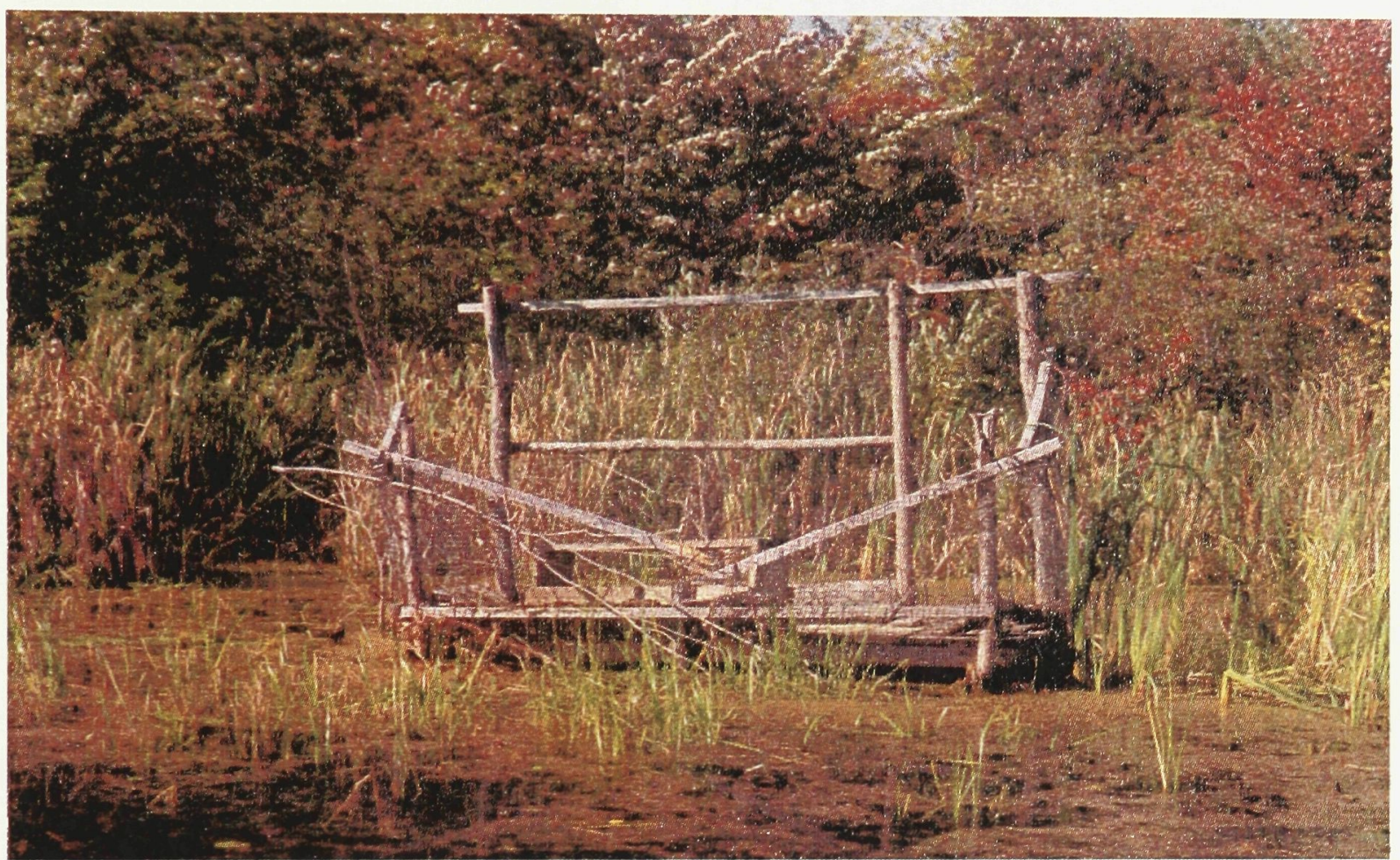

Figure 2 - Duck blind

will simply dissolve into nature leaving little or no trace of its prior existence. No pollution is left behind and the environment disposes of the materials through decomposition. On the other hand, the bird's nest (Fig. 3) or the tree house (Fig. 4), spoke of a different architecture; one which utilized the tree as its foundation and permanent structure in which to place an ephemeral structure for a short period of time. The tree not only offered stability and support for the adjacent structure, but also offered protection. 


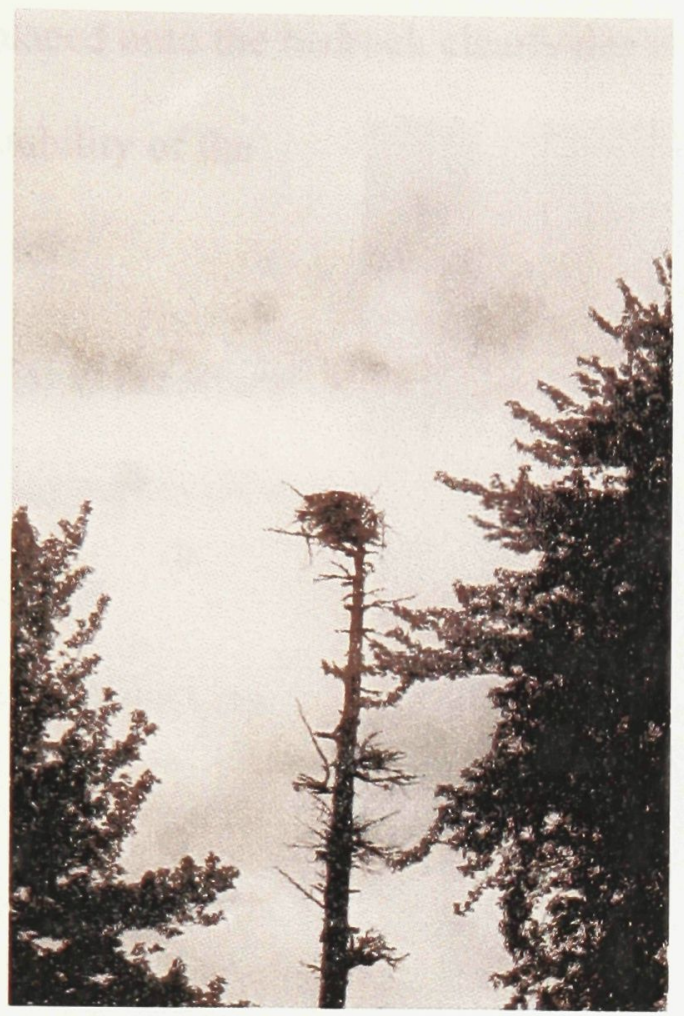

Figure 3 - Bird's nest

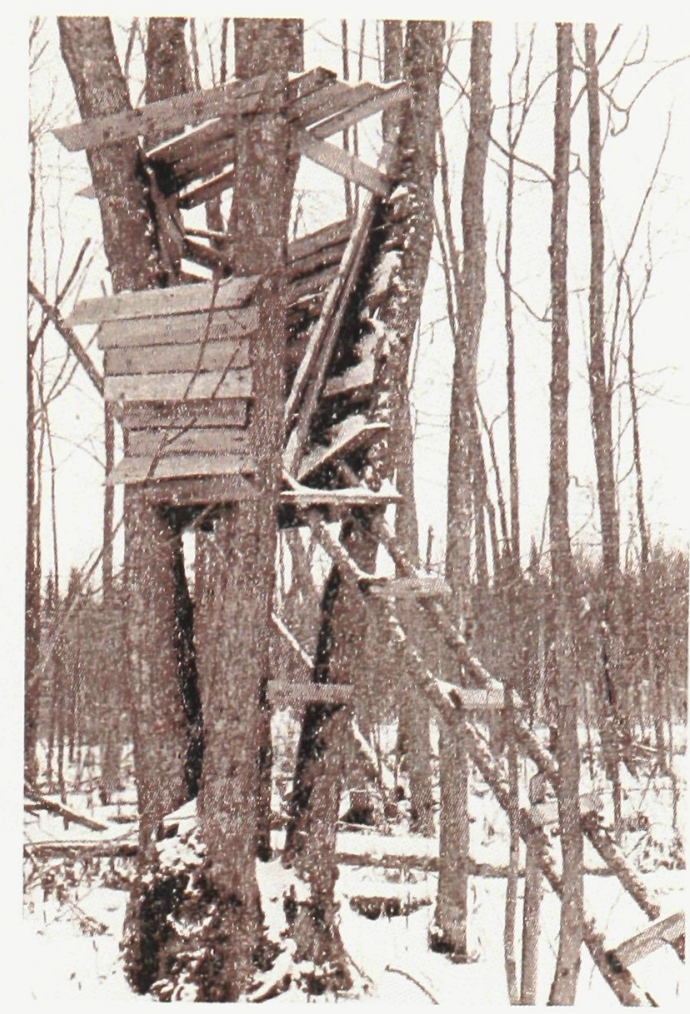

Figure 4 - Tree house

The man-made structures examined, provided evidence similar to that of the natural examples. For example, the train bridge (Fig. 5) is anchored into a stonewall, which acts as a foundation and a retaining wall, permitting the train tracks to span over the length of the river. There is very little intervention to the environment, and the

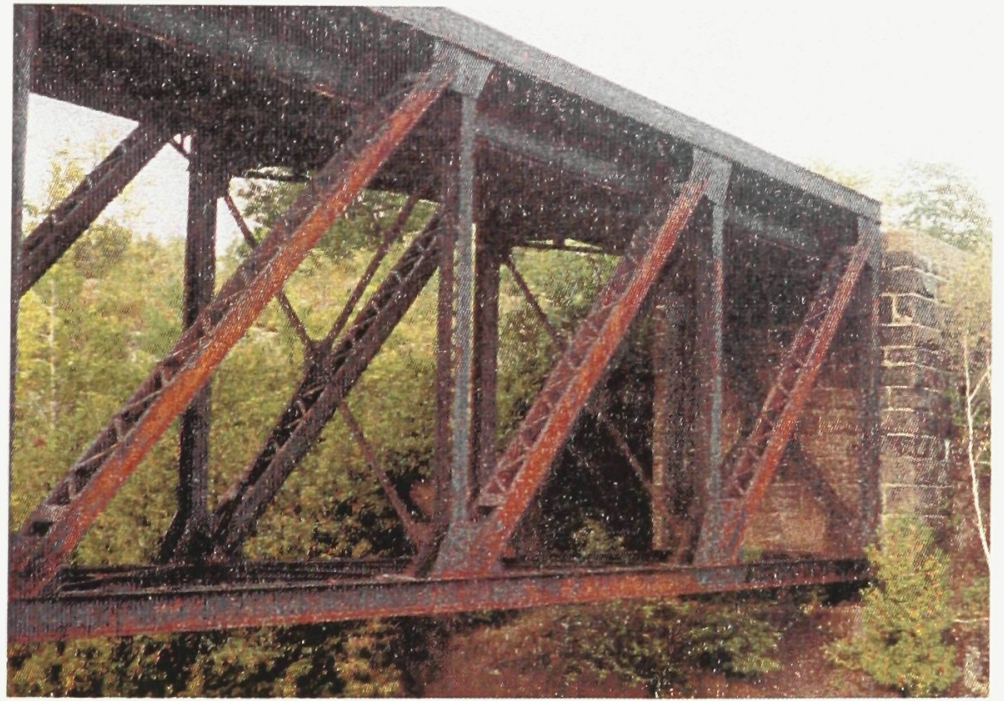

Figure 5 - Train trestle, Sturgeon Falls, Ontario structure in its entirety works quite well. Finally, Science North, a museum in Sudbury by Moriyama and Teshima Architects was examined because of its architectural integration within the natural environment. The glass wall (Fig. 6) 
placed onto the bedrock clearly demonstrates to the audience the durability and stability of the rock.

The architectural language is clear and its components are clearly defined.

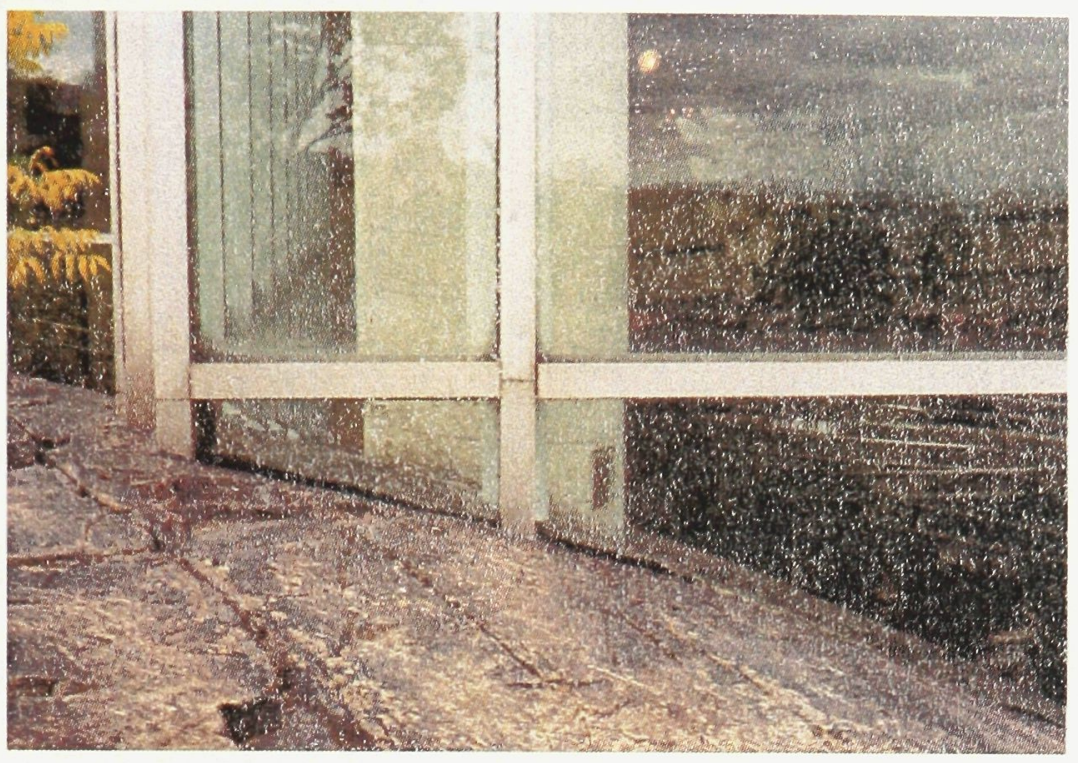

This example will

Figure 6 - Science North, Sudbury, Ontario

be examined in further detail when discussing other architects and their methods of dealing with the environment.

It became evident from these observations that the structures studied, either natural or man-made, appeared more ingenious architecturally because of their direct response to a certain need, as well as a clear response to environmental conditions. Why is it that structures as simple as a duck blind will be constructed in relation to its site, orientation, and climate, while other forms of architecture choose to ignore all these facets?

Technological advancements contribute to some of the problems discussed. Through technology or building processes, technological solutions are being found for problems that were previously dealt with in a more 'primitive way'. Bernard Rudofsky, author of Architecture Without Architects, reminds us that sometimes the most 'primitive' or simple solutions far exceed any other technological solutions that we, as Canadians, might deem acceptable. 
"We learn that many audacious 'primitive' solutions anticipate our cumbersome technology; that many a feature invented in recent years is old hat in vernacular architecture - prefabrication, standardization of building components, flexible and movable structures, and, more especially, floor-heating, air-conditioning, light control, even elevators."

Furthermore, advancements in technology, code requirements and building science allow and expect houses to be hermetically sealed. These new houses are often sealed so tightly that the people inhabiting them become ill due to a lack of air circulation. "Practicing architects frequently remark that due to local construction conventions, many envelopes have been overbuilt, [...] In other cases, evidence suggests that building envelopes have been under-designed, most frequently causing severe moisture problems compromising the integrity of the enclosure." hermetically seal a building, various new materials and products are created, many of which are toxic, impossible to dispose of, and serve only one function. But are these new technological solutions really solving anything? Rudofsky would certainly disagree by stating:

"There is much to learn from architecture before it became an expert's art. The untutored builders in space and time - the protagonists of this show - demonstrate an admirable talent for fitting their buildings in to the natural surroundings. Instead of trying to 'conquer' nature, as we do, they welcome the vagaries of climate and the challenge of topography.",

${ }^{5}$ Bernard Rudofsky, Architecture Without Architects (New York: Doubleday \& Company, Inc., 1964)

\footnotetext{
${ }^{6}$ Ted Kesik, "Principles of Enclosure," Canadian Architect 47.3 (2002): 35.

${ }^{7}$ Rudofsky
} 
What changes, events, or movements led Canadian architecture to break the balance between an environmental-based architecture to one based in current established norms? This problem will be addressed by generally examining the history of Canadian architecture throughout the years.

A Selection of Past Traditions/Methods of Construction in Canada The first architectural forms in Canada were derived from the harsh climatic conditions found in this country. From the Inuit igloo (Fig. 7) to the Native Longhouse, each method of

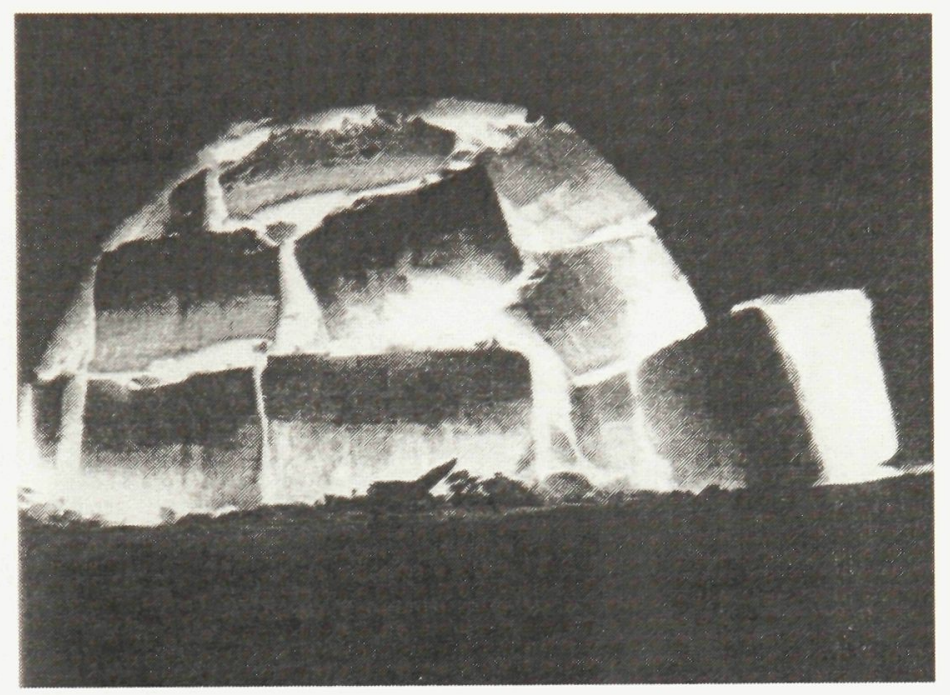

Figure 7 - Igloo construction expressed a need to provide shelter from the elements. Both were built from materials readily available, and both maintained a harmonious relationship to nature.

"In the centuries preceding permanent settlement in northern Canada seasonal and semi-permanent camps did radiate self-assurance. The people living in them chose their building sites intuitively, making the best of formations and materials offered by familiar landscapes. Impermanence made site improvements possible the following season; in the off season, wind, snow, and rain freshened the site, returning it to inventory."

With the arrival of European settlements, new construction methods and styles were introduced to the colonies in Canada. "Having nothing to learn from the primitive 
huts of the Indians they encountered, even its settlers had of necessity brought with them their own vernacular customs." 9 It should be noted that these new styles were often modified in response to climate, availability of materials, and craftsmanship.

With the modern and post-modern period, a crisis arose throughout the world. How could architecture remain innovative while retaining a sense of tradition? In the past, Canada had always copied other styles and modified them to some extent to suit its needs. During the modern movement, there was a romanticized view that only European and American architecture was worthy of attention. This was partly due to technological advancements that were sweeping throughout the world. Canadians had a desire to follow the architecture of the times and surround themselves, with what they believed to be more advanced sophisticated models. Because of these phenomenons, European or American styles were brought to Canada where they were constructed completely out of context.

"While basic changes in architectural style may take place organically, they have usually been imported. Publications such as Stuart and Revett's measured drawings of the Acropolis or images gathered from a European tour by people like Thomas Jefferson have determined the course of architectural history. Propagated by the architectural elite, they may or may not serve the aspirations of the people they are supposed to reflect. [...] The cultural aspirations of a people might therefore be met with an architectural expression that is basically foreign to them."

This created an architecture, which lacked meaning and tradition, to the areas affected. There was also no relation between building and site. They had become objects placed in various locations with no reasoning behind their construction at that

\footnotetext{
${ }^{9}$ Anthony Jackson, The Future of Canadian Architecture (Halifax: Tech-Press, 1979) 11.

${ }^{10}$ Jackson 8.
} 
particular emplacement. Another important aspect to point out is that many of these designs were not suitable for our climate because of the premature deterioration of materials. "These National monuments transposed the stones of Venice to the north, adapting the fragile elements and materials from the mellow south to the harsh northern climates, thus making them resistant to steady if gradual degradation across centuries."11 Models from Europe and the United States were not designed for a flux in temperature, which is very common for most of Canada. This created catastrophic consequences, such as the failure of building envelopes, once placed in a harsher environment. A building envelope, which functioned in a warmer climate, might not function as efficiently in a colder region, allowing mildew to grow in the walls due to moisture penetrating the exterior structure.

The industrial revolution greatly affected the way buildings were constructed. With this new technology, people seemed to believe they could control nature. As a result, man distanced himself from nature with the belief that he could overcome it. Today, we are beginning to understand that the relationship between man and nature must be re-established in order to minimize the negative impact humans have on the planet.

Certain political forces also affected the way architecture was practiced in Canada. In Georges Grant's Lament of a Nation: The Defeat of Canadian Nationalism, the implications of transforming Canada into a sovereign nation were discussed. With the modern era, there was a new sense of homogeneous and universality that had not been there before. As Grant states "Modern Civilization

${ }^{11}$ Essy Banissad, ed., Architecture Canada 1999: The Governor General's Medals for Architecture (Halifax: Tuns Press, 2000) 11. 
makes all local cultures anachronistic. Where modern science has achieved its mastery, there is no place for local cultures." 12 During this period, it was inevitable to fall into the traps of technology, but it is important to understand where a country stands when faced with it. "Nationalism can only be asserted successfully by an identification with technological advance; but technological advance entails the disappearance of the indigenous differences that give substance to nationalism."

Aside from the movements and events previously discussed, there are also other factors, which hinder the architecture produced in Ontario. The Ontario Building Code, although created to ensure a minimum level of quality and safety, often acts as a barrier, rather than a catalyst for good design. Its restrictions do not take into consideration other alternatives to the norm. Therefore, the same models are often repeated to facilitate the approval and requirements of building officials. Zoning is another factor, which helps establish a norm for housing. Due to setbacks and zoning restrictions, one cannot always take full advantage of the resources at a particular site.

Financial institutions are also a deterrent to innovative architecture. In order to obtain the money required to build a home, most people are forced to acquire mortgages. To do so, the bank must establish certain criteria such as the number of rooms one can have. If the house is not designed within the predetermined models, some banks might refuse to loan money altogether, judging the risks too high.

${ }^{12}$ Georges Grant, The Lament of a Nation: The Defeat of Canadian Nationalism (Montréal: McGill-Queen's University Press, 2000) 67-68.

${ }^{13}$ Grant 88 . 
It should also be noted that there is little, if any government support for designs out of the norm. If one desires to heat his/her house with solar panels, there is currently no support or encouragement to do so from government agencies. Rather, there are varying degrees of obstacles one must overcome before obtaining the approval for such systems. These systems also cost more to purchase and install compared to conventional heating/cooling/ventilating systems.

The combined forces of technology, social and political influences as well as economical obstacles prove the existence of preconceived notions within the house model, and why it is so difficult to redefine these criteria. Unfortunately, this practice of architecture seeks to overcome nature, rather than embrace it.

\section{Preconceived Notions}

Employing technology to circumvent the environment has allowed our perception to change. "Often, nature is therefore regarded as a source of inspiration, or more generally, as a bucolic context to which an equally serene architecture could respond; or further, it is regarded as a state of balanced existence with which architecture should be integrated." 14 There appears to be a romantic view of architecture and its relation to nature. Nature is thought to be harmless, hence easily controlled. "The form and structure of northern cities has not been shaped by climatological dictates but rather has employed technology to make habitable designs and shapes which are fundamentally unsuited to their respective sites and geographical locations." ${ }^{\prime 15}$ Rather, architects need to take a step back and re-examine the design process established in the past, which is more indicative of the

\footnotetext{
${ }^{14}$ Banissad 12.

${ }^{15}$ Mänty 30.
} 
environment. "Aware of the finality of resources, the minimal [objective] in a complementary architecture [should maintain] the fragile balance between the constancy of nature and the temporariness of human presence." $" 16$

There is no disputing that architecture has changed tremendously over the years, but its present direction is alarming. If current trends continue, Westerners will be faced with depletions of natural resources, rising maintenance costs, overwhelming landfills, and a loss of tradition in architecture. Will only the depletion of fossil fuels cause society to re-examine these issues? "Just sixty years ago central heating and insulated walls were a novelty in North America. The expression 'building envelope' had no meaning."17 Today, the expression "building envelope" dominates the industry, and technological advancements are created to resolve the issues or problems with these new methods of construction. We are utilizing technology to solve problems that were caused by utilizing technology in the first place.

In order to further this discussion, the general history of Verner, Ontario will be discussed to determine more specifically how technological advancements affected the architecture produced in this farming community.

\section{History of Verner}

In 1883, over 15, 000 men worked on the construction of the Canadian Pacific Railway in Northern Ontario. The railway was the realization of a national vision of creating a cross-continental link between the East/West borders of Canada. As a result of this cross-continental railway, most Canadian cities and towns were built around the rail system to ensure social, political, and economical links with the rest of

\footnotetext{
${ }^{16}$ Banissad 13.

${ }^{17}$ Strub 80.
} 
the country. Verner was no exception to this phenomenon. When the railway progressed from North Bay to Thunder Bay, Ontario, some of the men working on the railway decided to establish themselves in the Verner area (Fig. 8).

A small rural community of approximately 1,000 inhabitants, Verner, Ontario

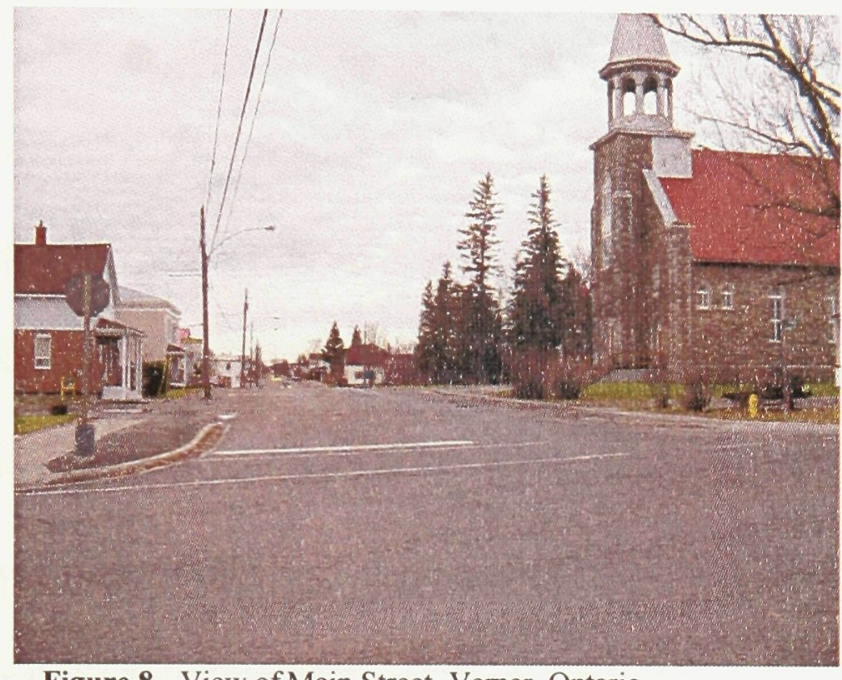

Figure 8 - View of Main Street, Vemer, Ontario is located on Hwy 17, $56 \mathrm{~km}$ West of

North Bay and approximately $72 \mathrm{~km}$

East of Sudbury. Prior to the

municipality of West Nipissing's

amalgamation in 1998 (combining

Cache Bay, Crystal Falls, Dokis First

Nation, Field, Kipling, Sturgeon

Falls, River Valley and Verner), Verner was located within "The Caldwell

Township." This township covered an area of nine miles North to South and another six miles in the East/West direction. The land was divided into 9 concessions, with lots numbered 1 through 12 . The actual village of Verner is built on lots 8,9 and 10, and concession 4 (Fig. 9).

When the settlers began purchasing land, agriculture soon became a major economical force for the community. Surrounding towns, like

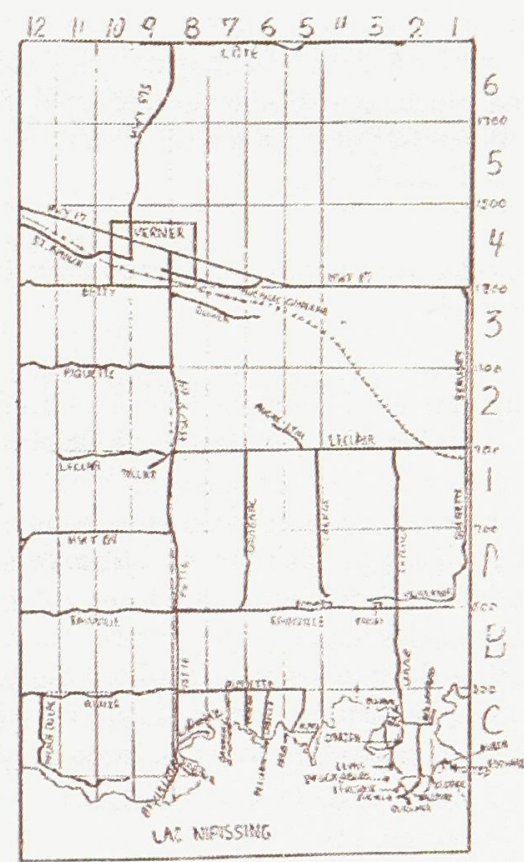

Figure 9 - Caldwell Township Divisions Sturgeon Falls, opted for larger industries rather than agriculture. Sturgeon Falls is located $16 \mathrm{~km}$ East of Verner, and is the largest town within the municipality of West 
Nipissing with a population of 6,000 inhabitants. Due to their close proximity, the two areas maintained a symbiotic relationship while still maintaining a distinct separation in terms of identity.

Since each area sought a clear distinction from their neighbours, certain traditions and construction methods were established. The reasoning or conditions behind these methods of construction will be discussed in detail, as well as the events that led to their disappearance. The focus of the discussion will be limited to Verner, but many points noted about this town are valid for most farming communities in Northern Ontario. The traditional methods of construction will be discussed generally, while specific case studies will be examined in detail in order to obtain a more critical analysis of these processes. The purpose of the following discussion is to bring the reader's attention to fading traditions, which might provide us with solutions to problems found today.

When looking at Verner's architecture, one quickly realizes the implications agriculture had on the built form. In the 1900's, agriculture was simply and unquestionably a method or practice of self-sufficiency.

«On cultive le blé dont on obtient de la farine, l'orge utilisé pour l'alimentation des animaux, les pois pour consommation humaine, l'avoine pour les chevaux. Le foin est vendu aux chantiers; les patates, faciles à conserver, sont un aliment important pour la famille et les chantiers. L'élevage du mouton permet la production de laine, les vaches donnent le lait et la viande, les porcs se transforment en lard salé et les chevaux sont utilisés pour les travaux de la ferme.» ${ }^{18}$

${ }^{18}$ Gerald Beaudry et al., Verner: Cent ans d'histoire à raconter. .. (Verner: Bureau du canton de Caldwell, 1995) 110. 
"We cultivate wheat from which we obtain flour, we feed the animals with barley, and the peas are for human consumption, oats for the horses. The hay is sold at construction sites; the potatoes, easy to preserve, are an important food source for the family and the workers. The breeding of sheep allows for the production of wool, the cows give milk and meat, the pigs transform themselves into salty bacon and the horses are used for farm work."

Agriculture was structured as such to ensure families could live off the land, while taking full advantage of their surroundings. With no electricity or machinery, the farmer sought all environmental advantages to help with the upkeep and maintenance of his farm. Even the physical layout of the farm had to be carefully established to ensure maximum efficiency of the natural resources available. L'institut Agricole D'oka, an agricultural school in 1929, published a series of books entitled Cours D'Agriculture. The school's mandate was to educate and inform young French Canadian farmers on the importance of agriculture and the proper ways to manage a farm. Established in 1893, the institution sought to create a rural elite, educated with the fundamentals of agriculture. «'L'heure est venue pour les prêtres de la campagne de former une élite professionnelle agricole', écrit en 1928 Mgr Fabien-Zoël Decelles, évêque de Saint-Hyacinthe, dans le Bulletin de la ferme, publication destinée aux cultivateurs.»" "The time has come for the rural priests to form a professional agricultural elite", written by Mgr Fabien-Zoël Decelles in 1928, bishop of Saint-Hyacinthe, in the 'Bulletin de la ferme,' a publication destined for cultivators."

${ }^{19}$ Diane Baillargeon and Denis Plante, "Quand l'Université créait des poules et des melons: l'Institut agricole d'Oka a connu sept décennies de prospérité," Iforum 37.9 (2002), 28 Oct. 2004 $<$ http://www.iforum.umontreal.ca/Forum/ArchivesForum/2002-003/021028/article 1604.htm>. 
The books published by the institute were used and distributed among some of the farmers in Verner. In one section of the Cours D'Agriculture, the physical layout of the farm is explained as such:

«Organiser une ferme physiquement, c'est:

1. lui donner un profil qui favorise l'écoulement des eaux et réduise au minimum tous les obstacles aux travaux de culture;

2. $[\ldots]$

3. situer toutes les améliorations (constructions, plantations, fosses et rigoles, chemins et clôtures, ponts et puits) aux endroits les mieux appropriés pour assurer leur pleine efficacité en même temps que leur entretien économique; $\rangle^{20}$

"Physically organising a farm is:

1. To give it a layout which facilitates the drainage of water and reduces to a minimum all obstacles that would interfere with agricultural work;

2. $[\ldots]$

3. To locate all the improvements (constructions, plantations, trough and channel, roads and fences, bridges and wells) at appropriate locations to assure their full efficiency, while also considering their economical implication required for maintenance."

Even if many farmers were not educated, or did not follow these manuals, they were still aware of the proper farm management and construction methods. Bill N. Lacy stated in the forward of The Barn: A Vanishing Landmark in North America:

"When man builds without giving any thought to 'art' or toward creating something of beauty. When he builds to satisfy a well-stated function without frills, and when he is forced to build within narrow restrictions of materials and methods, the results, as with barns, are consistently the material of which museums are filled."21

It should be noted that many farmers placed more importance on their barns than their actual houses. The barns symbolized the hardships, traditions, and joys of

${ }^{20}$ Institut Agricole D'Oka, Cours d'agriculture - Tome 1, 3rd ed. (Québec: Institut Agricole d'Oka, 1948) 39.

${ }^{21}$ Bill N. Lacy, forward, The Barn: A Vanishing Landmark in North America, by Eric Arthur and Dudley Witney (Toronto: M.F. Feheley Arts, 1972) 7. 
agriculture. Therefore, different approaches were taken in the construction of the house and the barn. When examining the barns in Verner, it was observed that many copied the Dutch style. Although many settlers arrived from Quebec, they still preferred the Dutch style to the Quebec style, because it was more easily adaptable to their needs.
"The plan of these Dutch North American barns has come to be called 'basilican' by historians, and the term is obviously apt. It came about, perhaps as long ago as two millennia, to meet the requirements of a central wide space for threshing that was convenient to narrower spaces for cattle and horses, and a simple structural system in timber that would support the roof and a snow load, as well as whatever was stored as fodder over the threshing floor. There might have been other ways of handling the former, but as the animals faced into the nave from which they were fed, it was a functional and very practical solution., ${ }^{, 22}$

When examining the 'basilican' plan in greater detail, one will notice, "there are no doors at the east end to match those at the west [.] ${ }^{, 23}$ The first barns built in Verner followed this model accurately, but due to climatic difficulties, the orientation was changed from East/West to North/South. This change in orientation allowed for more light to enter the buildings when it was most needed.

The Dutch plan was established in the area when various European immigrants arrived in Canada, bringing with them skills and knowledge handed down from father to son for countless generations. The French settlers of Verner, appreciated the advantages of the style, embraced its adaptability, copied it, and applied it to their own needs. It should be noted that not all barns examined followed

\footnotetext{
${ }^{22}$ Arthur 37.

${ }^{23}$ Arthur 37
} 
the Dutch style precisely. Many variations were created to accommodate altering landscapes and climatic complications.

As a result of the abundance of raw materials on the land, most settlers built their homes and barns from products found on their properties. «Il y a certainement du bois de qualité, car les premiers colons construisent leurs bâtiments avec le bois de leur terre. On peut observer certaines granges bâties vers 1900 avec des poutres de 12 pouces sur 12 pouces, équarriers à la hache et longues de 45 pieds.» "Certainly there was quality wood, since the first settlers built their buildings with the wood found on their properties. We can observe certain barns built around 1900 with beams 12 inches by 12 inches, measuring 45 feet in length, squared with an axe." The settlers learned very quickly to utilize what was at hand, and established a construction process, which suited their needs and the materials available. As a result of these conditions, a local architectural vernacular was soon established, in which local materials, climate, and past traditions were taken into account.

Although the old farmhouses and barns of the area were built in direct correlation to climate and the environment, other important factors also affected the built form. When agricultural properties became scarce, the government implemented certain regulations in the sales of the remaining properties.

«-L'acheteur doit être de sexe masculin (ou une femme sans soutien), chef de famille ou célibataire, agé de plus de 18 ans;

-La vente d'un demi-lot, c'est-à-dire 160 acres, se fait aux conditions suivantes: $0,50 \$ 1$ 'acre, un quart du prix total au comptant et le reste en trois paiements annuels égaux portant un intérêt de $6 \%$;

-L'acheteur doit s'établir sur son terrain en moins de 6 mois, construire une maison habitable d'une dimension minimale de 16 pieds sur 20 pieds, défricher et cultiver au moins $10 \%$ du terrain acheté et y demeurer pendant trois ans;

\footnotetext{
${ }^{24}$ Beaudry 35 .
} 


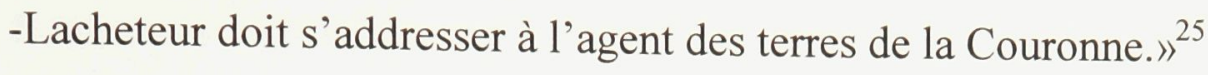

"The buyer must be male (or a woman with no economic support), head of a family or a bachelor, 18 years or older;

-The sale of half a lot, which is 160 acres, is done under these conditions:

$\$ 0.50$ the acre, one quarter of the total price in full and the rest to be paid in three even annual payments with an interest of $6 \%$;

-The buyer must establish himself on his land within 6 months, build a suitable house of a minimal dimension of 16 feet by 20 feet, clear and cultivate at lest $10 \%$ of the land bought and live there for three years. -The buyer must address himself to the land agent of the Queen."

These regulations established a certain trend for the region. One can still observe many farmhouses measuring approximately 16 by 20 feet. It can be noted that over the years various additions have been made to these homes reflecting social, political, and economical changes in the area.

The influence of climate cannot be taken lightly. Due to the long winters and short summers, a limited amount of time is available to erect buildings. The materials would have to be collected during the winter, ensuring it would be ready for the relatively short summer, in which construction was facilitated by the warmer climate. «On commence par abbattre les arbres où seront situés les bâtiments. On construit une petite maison en bois rond pour loger la famille et une écurie pour les chevaux, les bêtes à cornes, les poules et les cochons. A l'époque, on vise l'autosuffisance: nourriture, vêtements, abri chaud pour la famille.» ${ }^{26}$

"We start by cutting down the trees where the buildings will be placed. We build a small house in round wood to lodge the family and a stable for the horses, the beasts with horns, the chickens and the pigs. At the time we aimed for self-sufficiency: food, clothing, warm shelter for the family."

\footnotetext{
${ }^{25}$ Beaudry 37-38.

${ }^{26}$ Beaudry 109.
} 
A second critical factor in the creation of Verner's vernacular architecture is the Pulp and Paper mill in Sturgeon Falls. This mill had a tremendous impact on the economical growth of the community, but also played a great role in establishing a local vernacular architecture.

"A year before the town was incorporated in 1895, Paget and Heath \& Co. of Huntsville built a mill on the Sturgeon River. Electricity was produced in 1898 by this new mill. In 1902, sewers and telephones were installed and the community developed very quickly. Wood has been the lifeblood of the community for the last 100 years. The Sturgeon River and Lake Nipissing have been the highways for millions of logs that have gone to markets around the world."27

Not only did the mill provide employment for the area, it also supplied a large number of materials. For years, most local residents bought their doors, windows, and siding at the mill. This led to a very distinct way of building. An example of this would be the white hardboard siding seen even today on the majority of old homes. It is important to note that although the discussion so far has been general, there were distinctive differences between the construction methods of houses and other farm buildings. The difference will be elaborated in more detail in the case studies following this discussion.

As previously noted, agriculture is a practice reflective of self-sufficiency. People did not buy things they could make themselves. If the item desired could not be made, services could be exchanged for it. Barring that, items could be purchased locally. With the slow closing of the mill from 1930 to 1947, Sturgeon Falls and all its neighbouring towns were faced with difficult years. "The lifeblood of Sturgeon

${ }^{27}$ Wayne F. LeBelle, Sturgeon Falls: 1895-1995 (Canada: Canadian Cataloguing in Publication Data, 1995) 23. 
Falls has been this mill and over the years many different owners have taken the town on a roller coaster. The most difficult time was from 1930 until the mill reopened again in1947."28 Not only were a vast majority of people out of work, but local building supplies now had to be imported into the area. Once the mill re-opened old patterns were re-established, but each time the mill closed one of its branches it both indirectly and directly affected the vernacular architecture of the area. "In 1991, MacMillan Bloedel closed down its hardboard siding plant laying off more than half of the mill's work force." 29 The closure of the hardboard siding plant is of substantial importance. The hardboard siding that had, over the years, covered practically all buildings that were not covered in brick, was now gone. This closure not only meant a closure for the mill, but also brought with it the realization of changing times.

"Confusing regionalism with parochialism, they sacrifice their own social values to architectural trends. Aiming to be part of a world-wide movement dedicated to producing the definitive symbol of our time, local needs are set aside in favour of a generalized solution."30 Although Anthony Jackson is referring to the International style in this remark, the same could apply to the habitants of Verner at the time. They were willing to sacrifice past traditions and culture in order to participate in the larger scheme of consumerism.

The highway is also an important factor in the transformation of architecture observed in the Verner area. With the arrival of cars and trucks, people were now able to travel more freely. This permitted people to be exposed to new products allowing

\footnotetext{
${ }^{28}$ LeBelle 94.

${ }^{29}$ LeBelle 101.

30 Jackson 15.
} 
new materials to be brought to the area at lower costs than by train. As a result, new forms of architecture slowly emerged in which past traditions, and cultures were slowly being assimilated to a general norm found marketed in other areas.

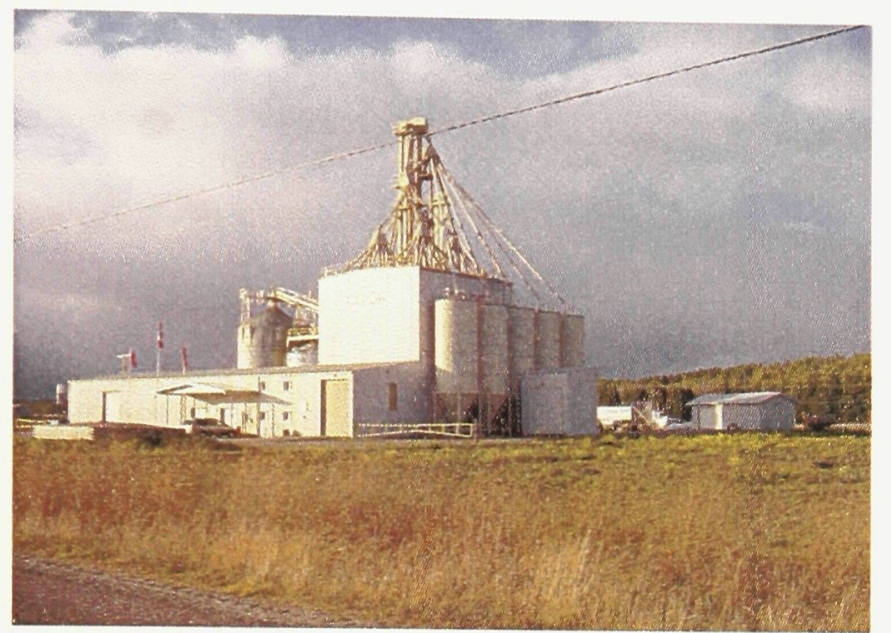

Figure 10 - Co-operative granary mill
When examining Verner

more closely in terms of its culture, it can be seen that other factors affected the growth of the community. For example, Verner was adamant about creating a $\mathrm{Co}$ operative granary mill (Fig. 10) for

the area that would supply the farmers with the services and products they needed. A Caisse Populaire banking institution was also established to accommodate the economic demands associated with farming. With various saw mills and the arrival of Brouillette Building Supply, a regional vernacular could not help but be established. Even to this day Brouillette, the Caisse Populaire and the Co-op are still active participants in the community's development. As Marie Rainville states at the beginning of the Verner Historical book: «Nos ancêtres, eux, nous ont laissé des coutumes, des traditions et un héritage remarquable que nous devons à notre tour léguer à notre progéniture. Je crois fermement qu'il est très important de comprendre nos origines: on développe ainsi un sentiment d'appartenance.»1

"Our ancestors have left us customs, traditions and a remarkable heritage that we must transmit to our children. I firmly believe that it is very important to understand our origins: as such we establish a feeling of belonging."

\footnotetext{
${ }^{31}$ Beaudry 11.
} 
In order to completely understand the past building methods and traditions of Verner, four case studies will be examined. These case studies were chosen on the basis that the farm had to have been passed down for more than three generations, the buildings had to be relatively intact, and they had to be accessible. The information discussed in these case studies is the result of interviews with the owners as well as some of my own observations while visiting these properties. A sincere thank you should be given to all the farmers who took time out of their busy lives to move and captivate me by their tales, which include the story of my own heritage and experiences.

\section{Case Study \# 1}

"La Ferme Paquette" Lot 9, Concession 4 and 5

\section{History}

Olivier Paquette, at 28 years of age, is the fourth generation owner of the family farm. Located in Verner on Paquette Road, north of Hwy 17, this 100 acre property is embedded with past memories, traditions, and cultural habits.

The farm was originally the property of Moïse Paquette, father of 12 children. In 1883, Moïse emigrated from St.Eugene, Ontario via the rail road and established his farm and family in Verner. The farm was then passed on to Victor Paquette (Moïse's last son), who would father 10 children of his own. Donat Paquette inherited the farm from his father and soon had five children. The last of his sons, Olivier Paquette, is currently managing the whole enterprise. 
Although the farm has changed over the course of the years, some aspects of it have retained their essence of tradition and culture. What are of interest on this particular property are the original homestead and the barn (Fig. 11).

Built in 1904, the house represents the construction methods of the times as well as the cultural and traditional values important to those who built it.

The barn was built in 1950, with an extension built in 1952. (This is not the original barn, but the second one to be built on the property. The original no longer exists.)

\section{Construction Methods}

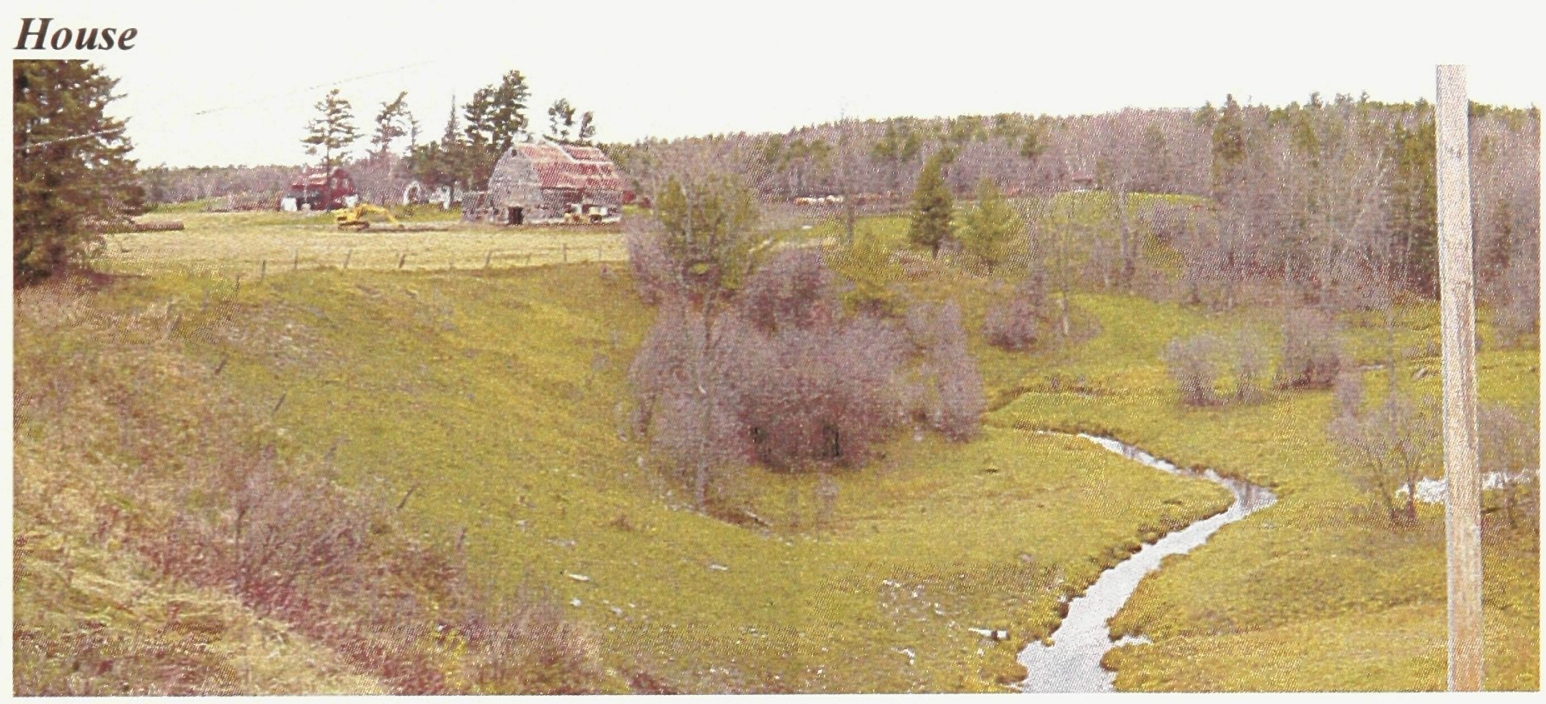

Figure 11 - The Paquette Farm, Verner, Ontario

The family and other members of the community built the house. This particular house has a crawl space rather than a full basement. It was common in the area to have a basement for the storage of food and wood, but this particular example did not have one. The earth at this location is clay, and this might have deterred the family from digging the basement by hand. The foundation consists of many rocks with cement poured around them. The usage of rocks in the foundation diminished 
the use and therefore, the cost of cement. The floor joists were positioned and the foundations poured around these, keeping them in place (Fig. 12).

The framing consists of 2"x 4 " studs assembled in what is referred to as balloon framing. The exterior walls were covered in rough wood planks

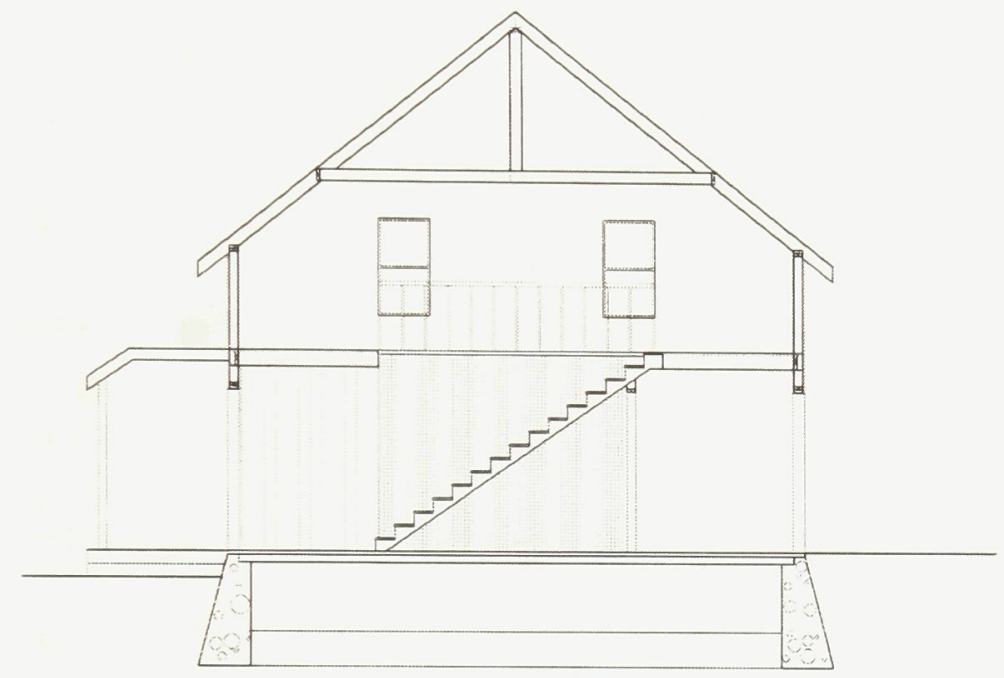

Figure 12 - Section (approximately $3 / 4 "-1 ")$,

which were covered in wood

siding originally, to be

replaced by "brick siding"

later on. The walls were

filled with wood shavings

that act as insulation. The

wood shavings had to be

mixed with agricultural lime to prevent the infestation of insects within the walls. The agricultural lime was produced on the farm with manure. The studs were then covered with wood planks nailed horizontally. These wood planks were then covered with smaller wooden laths, that were covered in plaster and then perhaps with wallpaper.

The entrance faces the South road (Fig. 13). A porch $\Lambda$ extending the length of the South 
facade protects the entrance. The majority of the windows were generally located on the South facade to facilitate heat gain, and diminish heat loss. The windows are single pane glass in a wooden frame. People avoided placing entrances facing North due to snow accumulation and winds penetrating the building.

\section{Barn}

As for the construction of the structure, Victor Paquette with the help of his family built the barn with his own hands using what was available on his property. All the wood used in the construction was cut in the wooded area at the back of the property and brought to a local sawmill (La scierie de Mr. Desrosier). The wood consisted mainly of red pine. The sheet metal for the roof and nails were purchased at the local store. As for the foundations, the family used rocks found in the surrounding fields and forest. These were hauled back either by hand or by horse. With sand, rocks, and some cement, the foundations were laid in place to a height of 7 ' -0 " (above grade) in the hillside, and 1' -0 ' (above grade) on the field side and the barn walls were erected on top. The order in which the structure was built is similar to the construction of a house today. The walls were framed on the ground and tilted into place with supports, until the other walls could be added. Each member of the roof was built on the ground and then hoisted up. The typical truss (truss in this case is referring to stick framing) (Fig. 15) for the region was what the locals call "un toit français." This type of roof was preferred since it allowed for a greater storage of hay within the trusses (Fig. 14). Lifting the trusses sometimes proved to be difficult without any available machinery. With the use of pulleys, horses, and sheer manpower, the barn was finally framed. 


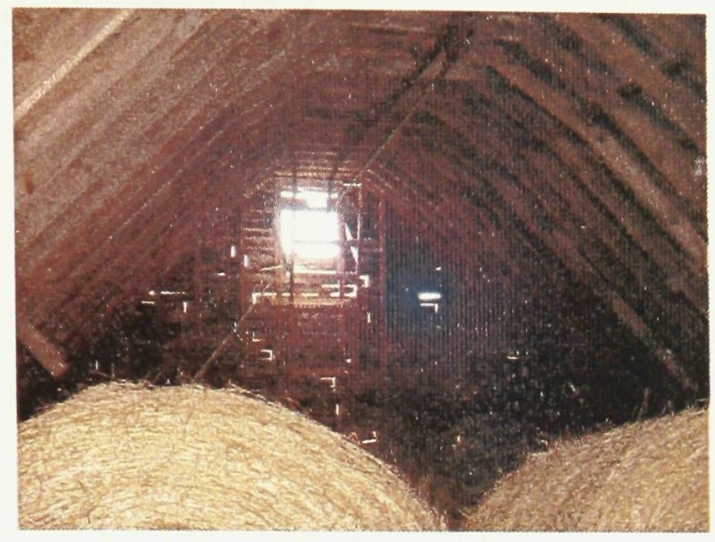

Figure 14 - The barn's hayloft

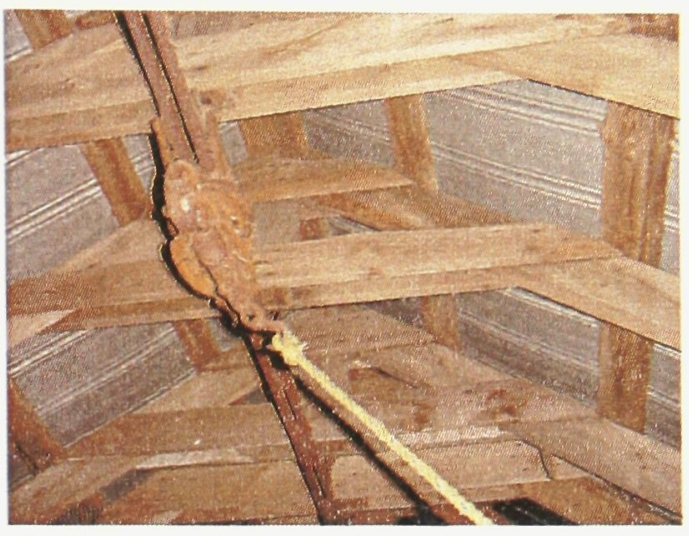

Figure 15 - The barn's roof members

A sheet metal roof was added and the walls were filled with wood shavings, which provided insulation (Fig. 16). Again, these would have been mixed with agricultural lime to deter the infestation of insects. The wood shavings were

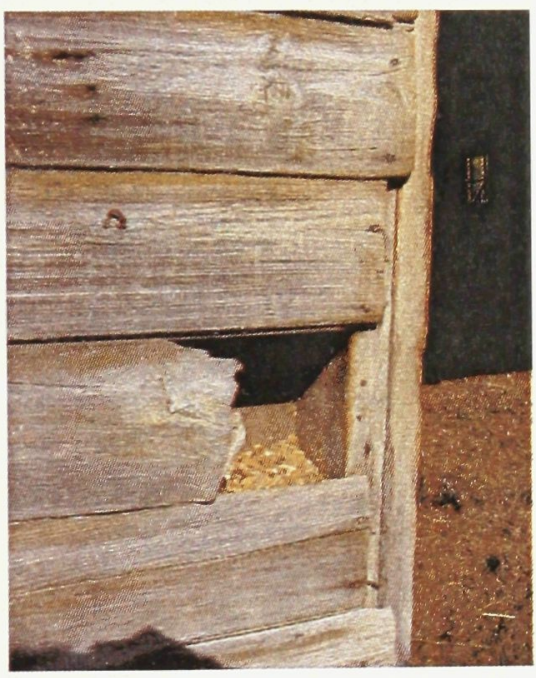

Figure 16 - Wood shavings within walls reclaimed from the wood cut at the local sawmill. It is important to point out that adding wood shavings alone inside walls of a barn was not common practice since it promoted the growth of insects, and infestation within the walls. The interior was finished with rough planks to keep the shavings within the wall cavities. As can be observed from the photograph, these shavings are

still present within the walls.

When looking at the photographs (Fig. 17) and the drawings (Fig. 18,19) one will notice that the barn was built on a hill. This allowed the farm animals easy ground access, while

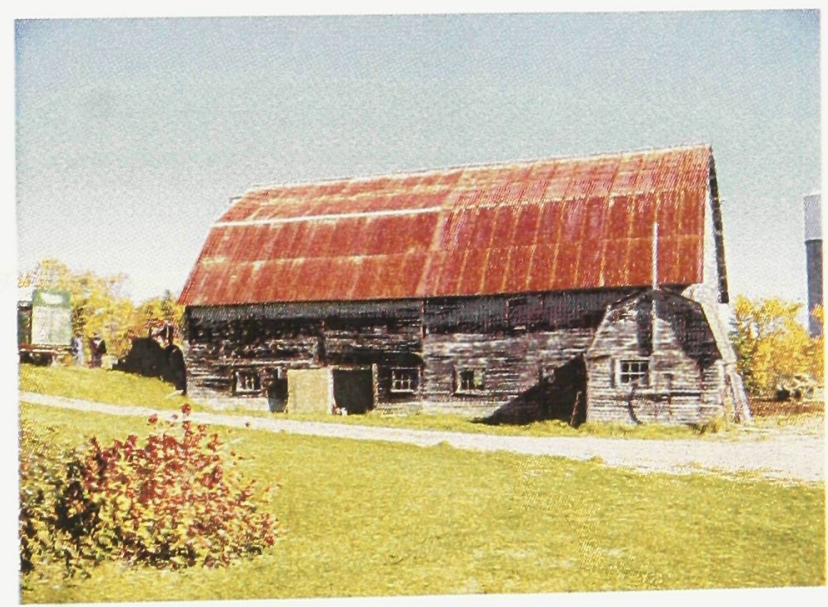

Figure 17 - Barn built into the hillside still allowing the farmer easy access to the upper storey for access of hay. Although 
simple in design, the topography is used to increase efficiency while minimizing cost and time for everyday chores.

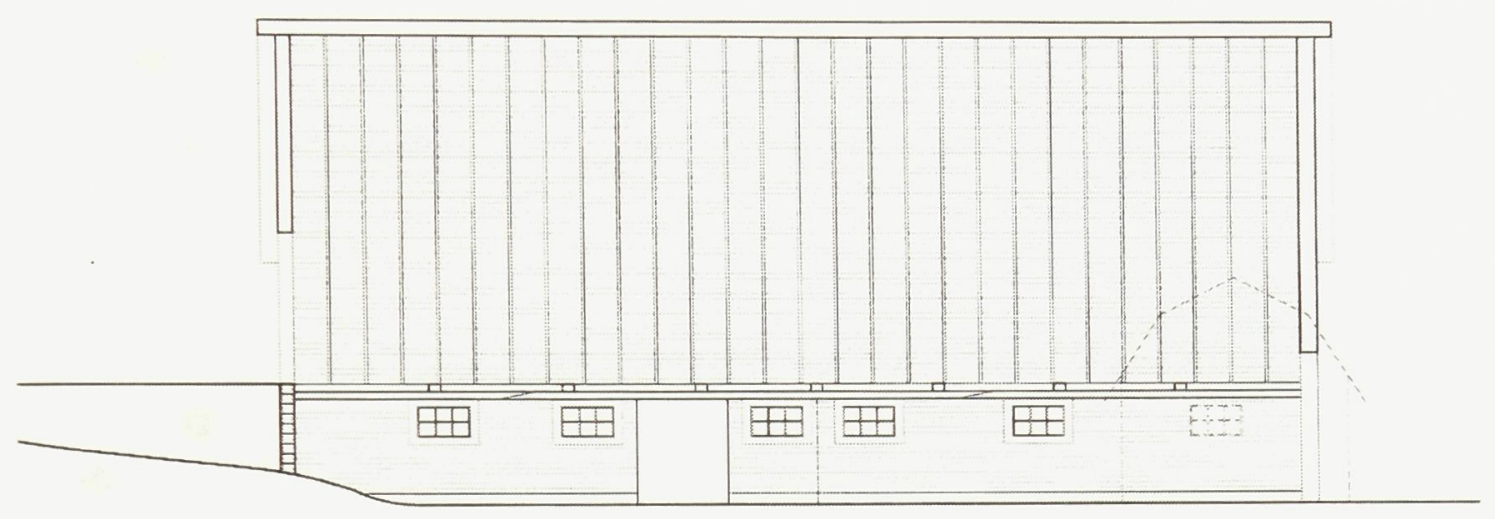

Figure 18 - Section

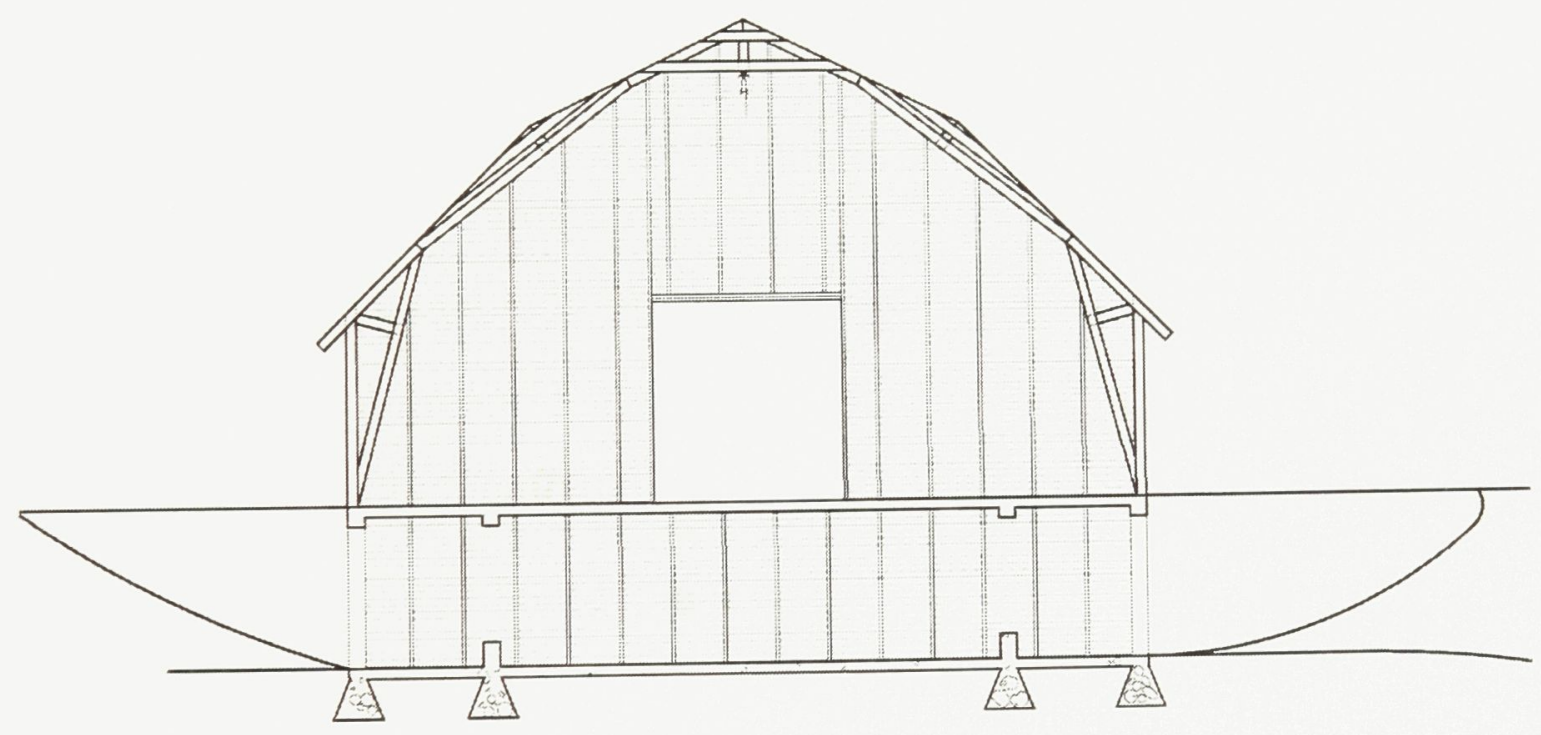

Figure 19 - Section 
When asked if there was a certain orientation in which a barn was placed on a property Donat Paquette indicated no, but mentioned that the original barn was located East/West and without electricity. Due to this orientation, there was not enough light to milk the cows. Subsequently, the second barn (the one remaining today) was built with a North/South orientation so that sufficient light would enter the barn from the side windows during the morning and evening for the milking of the cows.

As can be seen, many of the local traditions and building methods were derived from simple trial and error until efficient building methods became common practice in the area. These farmers do not profess having invented the style, but admit that within the community when somebody built something that worked well, all others copied the model. Everyone learned from each other, making collaboration essential. The people understood and used the environment to help them fulfill their needs. 


\section{Case Study \# 2}

"La Ferme Leclair" Lot 5, Concession 2

\section{History}

The Leclair farm has recently been sold outside the family, but beforehand had been passed down for three generations. Joseph Leclair (born in Quebec) emigrated from Michigan around 1910. At the time Joseph purchased the farm, the house was existing, but later was consumed by fire. In 1922, the house was rebuilt using the original foundations. Joseph had 10 children and left the farm to his son Lucien Leclair, father of 10 children. Lucien then left the farm to his son, Jean Marc, who sold the farm having no children of his own to pass it down to.

\section{Construction Methods}

\section{House}

A common practice of the time when it came to erecting buildings was to hold a "bee". A "bee" refers to the donation of time \& labour by members of the

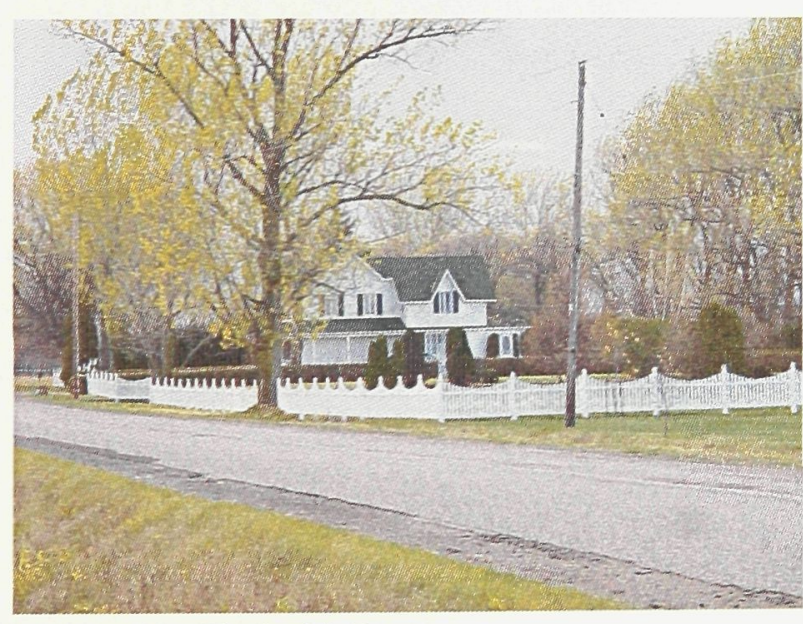

Figure 20 - The Leclair Farm community towards the construction of a building. After the Leclair household burned down, many members of the community, mostly the farmers on the lane assisted the family in the reconstruction of the home (Fig. 20). 
Eric Arthur and Dudley Witney eloquently state in their book The Barn: A Vanishing Landmark in North America: "Nowhere is democracy and the brotherhood of man better demonstrated than by the barn raising bee."32

In this example, due to the fire and the urgent need of a family dwelling, there was no time to cut down the wood so it was purchased locally. In terms of construction methods, it is very similar to the house examined in the first case study. The foundations were rock with cement holding them in place.

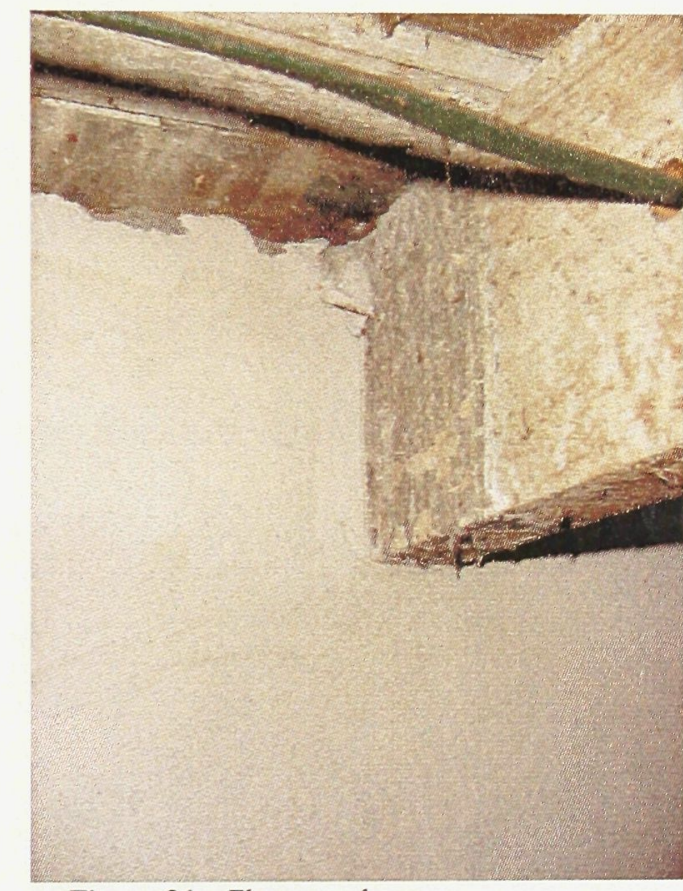

Figure 21 - Floor member
The floor joists were positioned and the foundations poured around them (Fig. 21). It is also balloon framed with 2 " x 4 " lumber at 24 " o.c. The walls were also filled with wood shavings and agricultural lime. The exterior walls were finished with rough planks and then covered with "ship-lap." The exterior was originally finished with "ship-lap," but was later replaced with "brick siding". In this case, the interior walls were finished with tongue and grove wood, which was either painted or covered with wallpaper. The roof consists of 2 " $x$ " stick framing covered with rough planks on which embossed tin panels were placed. The floors were finished with a row of rough planks and tongue and grove wood directly laid on top. This was either painted, or if money permitted, covered with linoleum. The doors and windows were made of wood, purchased at the local store. 
In this house, a basement was built which allowed for the storage of wood, coal, and vegetables. Although a stairway accessed the basement from the interior, an exterior entrance was added to facilitate easy access of products. One could bring the wood used for heating the house down to the basement without having to go through the main level.

The house was orientated with a South facing entrance. All the buildings were located near the river (Fig. 22), which provided the family with a year round supply of water. The wells of this time would have been manually dug, however the clay found in the area made this virtually impossible. Therefore, the drinking water was taken from the river and inflowing creeks. It was also important to be close to the water to ensure supply to the animals. A source of water was also important for

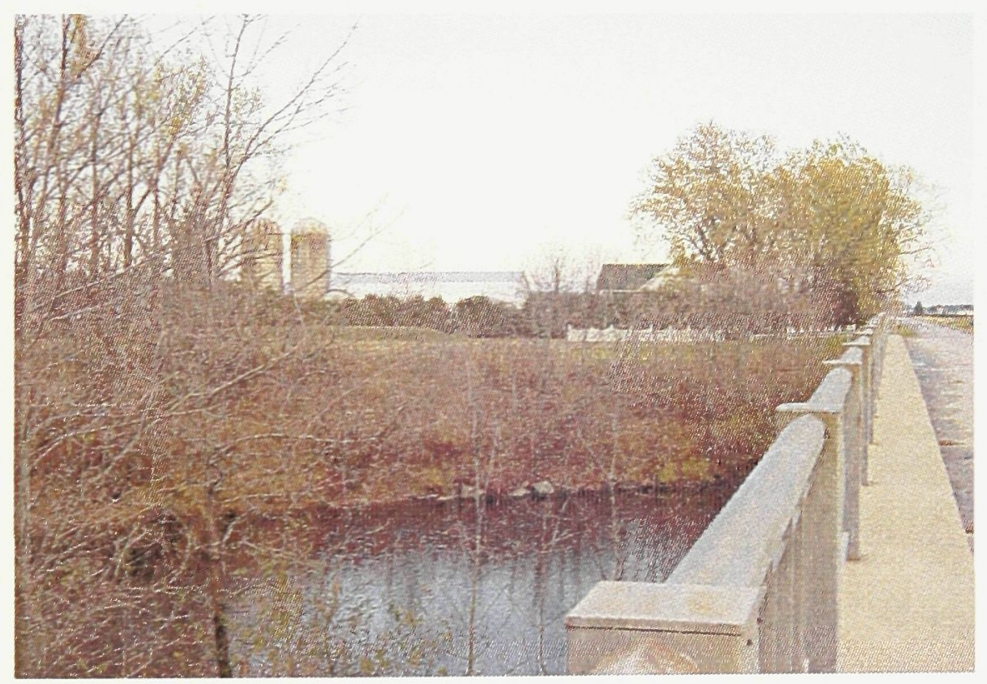
the supply of ice (taken in the winter), needed for the preservation of milk and food during the warmer seasons. This will be further explained in case study number four.

\section{Barn}

The barn examined in this instance was built in 1924. Like the house, a "bee" was used in its erection. The barn is located on the site with a North/South orientation, allowing for light to enter the building (windows face East/West) when it 
was most needed (milking of the cows). By placing the entrance on the South facade, there is a diminution of North wind entering the building during the winter months.

This barn follows the post and beam construction method. Wood (white or red pine) was cut down from the nearby forest during the winter months. Once the wood was cut, it was brought closer to the desired site where it was hewn by hand into a beam or post. This aspect of the construction required a skilled worker to cut away at a tree, ensuring straight sides and a square formation. All the pieces were cut to the correct lengths and then assembled on the ground before being raised into position. It is important to note that since nails were scarce and expensive, barns were built with very interesting joints (Fig. 23, 24, 25) to eliminate the use of nails. A dry fit was first established before the segments were assembled and then a section of the structure was raised and fastened into place. Men, horses, and pulleys were used to help lift these heavy structures.

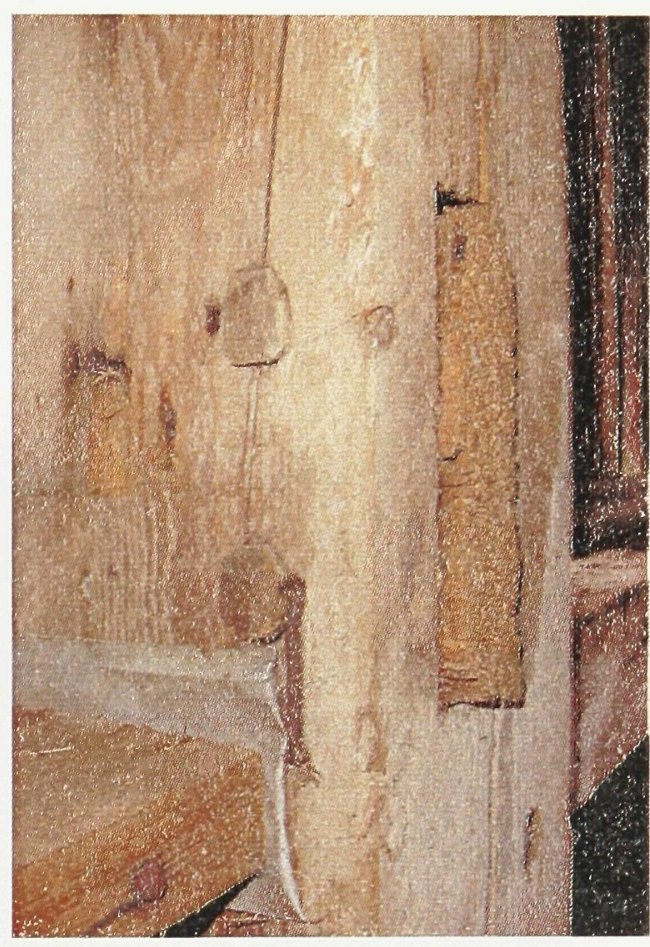

Figure 23 - A joint detail

"Even a glance at the carefully fitted members in the framing of the Dutch Barn will show that, however pressing the need for shelter, the work on the barn could not be accelerated any more than a cabinet maker could hasten the construction of a fine chest of drawers. With the help of a master carpenter, the framer/builder would behold after weeks of work the great skeleton of his barn on the ground, and only then would the semiskilled help of neighbours come into play. The erection of the frame, morticed and tenoned and pegged, entirely 
free from nails, even hand wrought, would be a day of triumph for all, but particularly the master carpenter. ${ }^{\text {"3 }}$

Similar to the barn in the first case study, the lower portion housed cows or other livestock and the upper area was used to store hay. The bottom portion was low in height 7'- 8' to diminish heat loss. With the hay overhead, it created great insulation for the animals. The roof, like the previous barn examined, is a "cone

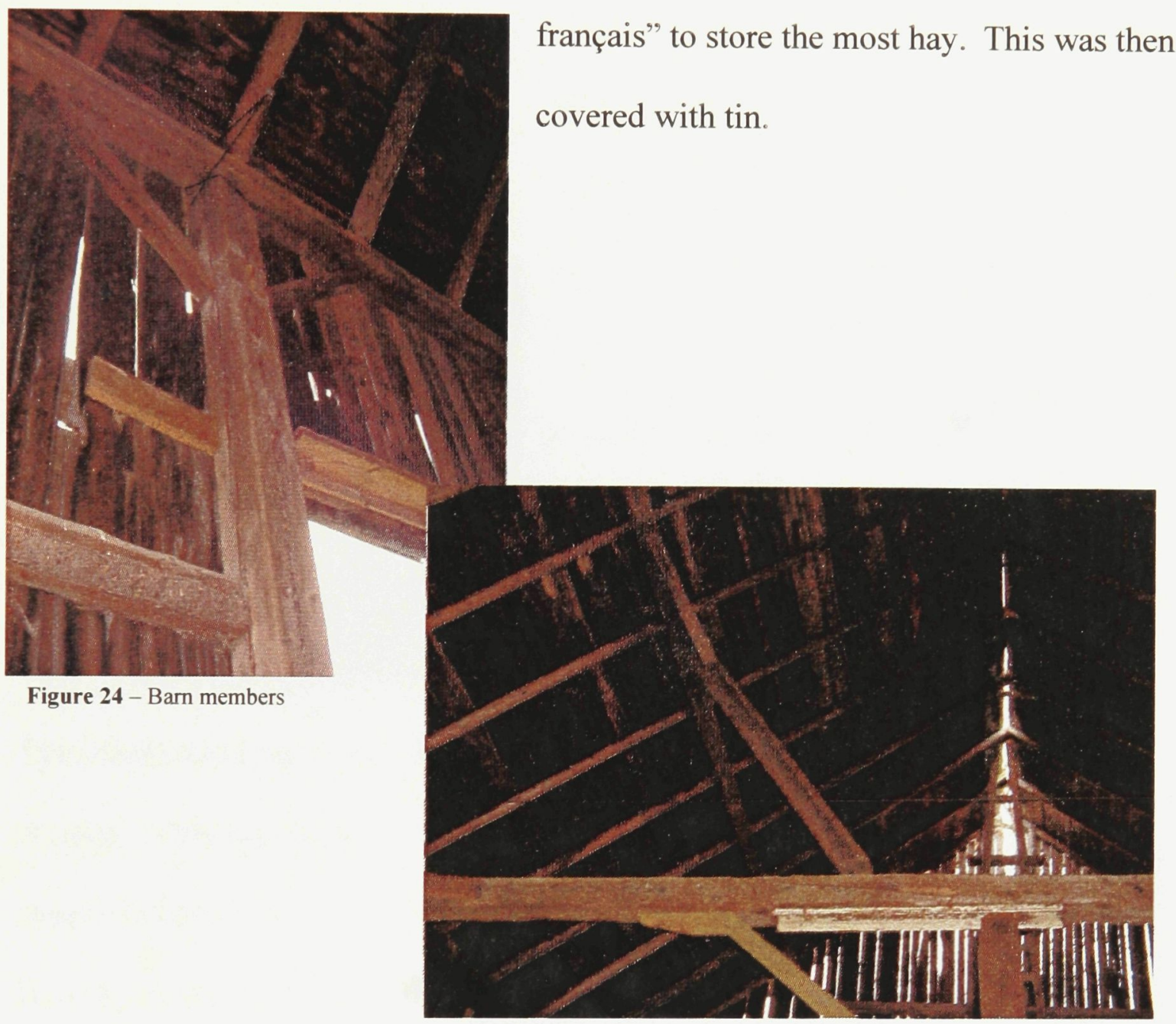

Figure 25 - A built up beam

\footnotetext{
${ }^{33}$ Arthur 44.
} 


\section{Case Study \# 3}

"La Ferme Beaudry"

Although this farm will not be discussed in much detail, one interesting feature is the granary.

\section{Granary}

As can be noted from the picture, this building is framed on the exterior rather

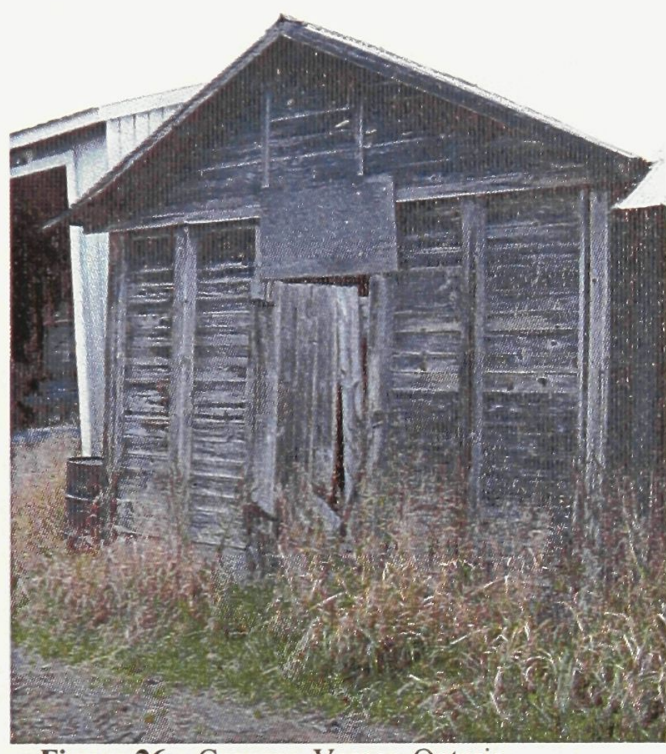

Figure 26 - Granary, Verner, Ontario than the interior (Fig. 26, 27). This was done to facilitate the removal of the grain from the building. In other words, the grain did not get stuck within the wall studs, eliminating any possible loss and creating an efficiency in which this building was used. Again, like many buildings on the farm, the building is orientated North/South with the entrance facing South.

This diminished the need to remove snow from the entrances during the winter months. Although quite simple in design, it shows how the residents of the area understood their needs and built in response to them.

They understood what materials they had available

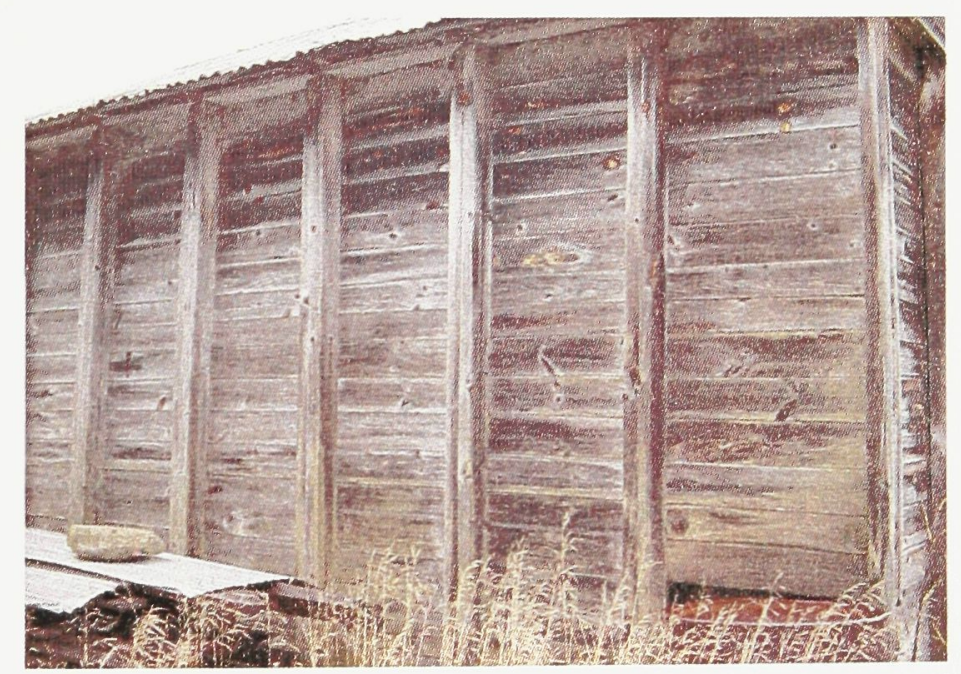

Figure 27 - Granary

and simply used them in different ways to facilitate their lives. 


\section{Case Study \# 4}

"Sturgeon Falls River House Museum"

The Sturgeon Falls River House Museum focuses its attention on the history of the municipality of West Nipissing. On this particular emplacement, one can find a series of buildings and structures demonstrating a past way of life. One of these structures is the ice house, typical on all old farms.

\section{Ice House}

The icebox, or house as its name suggests, was a building created to store ice. Having no freezers at the time, farmers had to devise a way to store the ice retrieved during the winter months and ensure that it remained frozen throughout the summer.

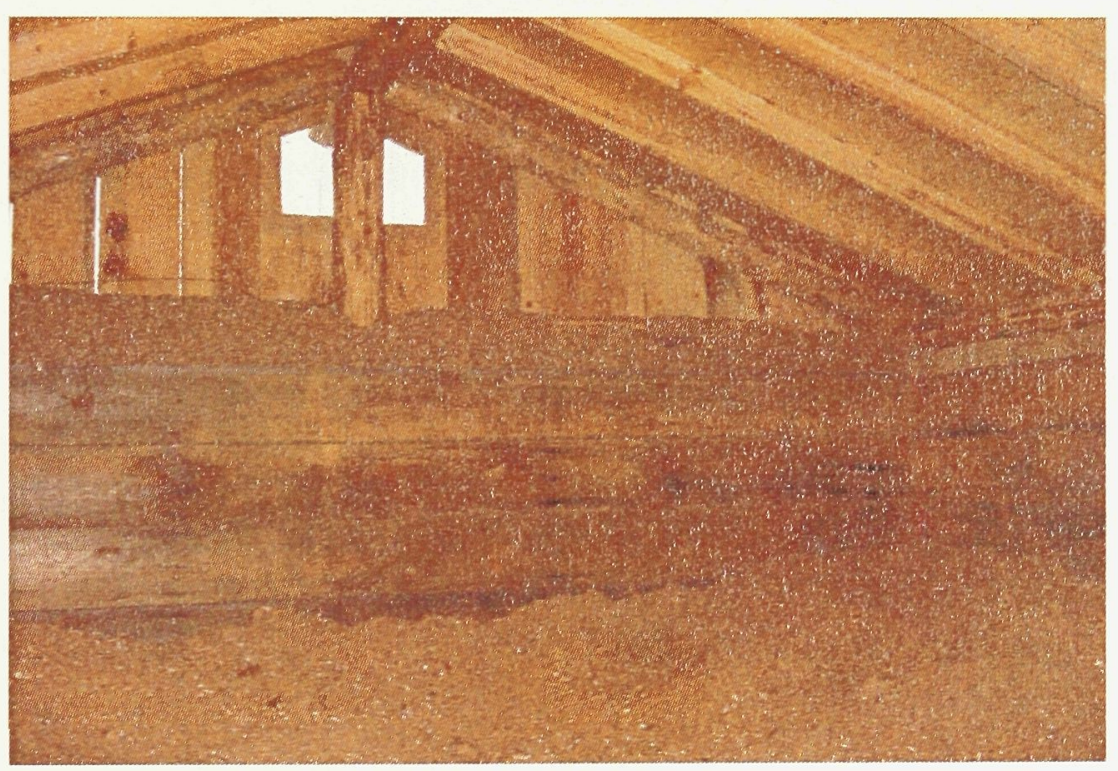

Figure 28 - Ice house
From this need, the ice house was invented.

This was a wooden structure either framed with timber or logs depending on the availability of materials.

Blocks of ice were cut

from the river during the winter, and then placed within the structure. All of this was covered with approximately one foot of sawdust, which ensured the blocks did not melt (Fig. 28). A block of ice was then removed each day to place in the milk house keeping the milk fresh. In the case of the icebox, the availability of local materials was critical. Without this structure, farmers would not have been able to keep their 
milk from spoiling. The proximity to a water source is also very important to ensure that blocks of ice could be cut and transported easily to the desired location. Another interesting facet to this structure is how it was re-used season after season. Once all the ice blocks were used, new ones were cut and placed within the structure. Then a new layer of sawdust was added over the whole and the process continued.
"In a lifetime, technology has been brought to bear on the barn as it has on the farm house, and this generation has witnessed the change on the old barns from roofs of thatch, of shingle, or of slate, the familiar and natural accompaniment to weathered pine, to metal. Hard, glossy and unsympathetic, the metal roof on an old barn is but a pointer that leads the farmer inevitably to a mail-order catalogue - a standardization of rural building, structure divorced from tradition and alien to the countryside. ${ }^{34}$

Technology has altered rural centres, threatening to assimilate past traditions and cultures with methods of construction that no longer speak of relationships to land, traditions, or even regionalism. People are blindly led to believe that a suburban home has more to offer than the years of knowledge accumulated by the predecessors of their area. 
Table 1 - Matrix summarizing the components examined for each case study

\begin{tabular}{|c|c|c|c|c|c|c|}
\hline \begin{tabular}{|l} 
Case \\
Studies
\end{tabular} & \#1 House & \#1 Barn & \#2 House & \#2 Barn & \#3 Granary & \#4 Ice Box \\
\hline \multicolumn{7}{|c|}{ Components } \\
\hline $\begin{array}{l}\text { Wind/ } \\
\text { Ventilation }\end{array}$ & $\begin{array}{l}\text { Building } \\
\text { was not } \\
\text { built air } \\
\text { tight, which } \\
\text { provided } \\
\text { ventilation }\end{array}$ & $\begin{array}{l}\text { Openings are } \\
\text { found at the } \\
\text { top of the } \\
\text { walls to } \\
\text { permit } \\
\text { ventilation }\end{array}$ & $\begin{array}{l}\text { Building } \\
\text { was not } \\
\text { built air } \\
\text { tight, which } \\
\text { provided } \\
\text { ventilation }\end{array}$ & $\begin{array}{l}\text { Openings are } \\
\text { found at the } \\
\text { top of the } \\
\text { walls to } \\
\text { permit } \\
\text { ventilation }\end{array}$ & $\begin{array}{l}\text { No saw } \\
\text { dust was } \\
\text { found } \\
\text { within the } \\
\text { wall studs } \\
\text { to facilitate } \\
\text { wind } \\
\text { movement, } \\
\text { hence } \\
\text { ventilation }\end{array}$ & $\begin{array}{l}\text { Opening } \\
\text { were } \\
\text { created } \\
\text { near the } \\
\text { roof line to } \\
\text { facilitate } \\
\text { ventilation }\end{array}$ \\
\hline Orientation & $\begin{array}{l}\text { Main } \\
\text { entrance } \\
\text { faces } \\
\text { South }\end{array}$ & North/South & $\begin{array}{l}\text { Main } \\
\text { entrance } \\
\text { faces } \\
\text { South } \\
\end{array}$ & North/South & \begin{tabular}{|l|} 
Main \\
entrance \\
faces \\
South \\
\end{tabular} & $\begin{array}{l}\text { Entrance } \\
\text { faces North }\end{array}$ \\
\hline $\begin{array}{l}\text { Sun/Solar } \\
\text { Gain }\end{array}$ & $\begin{array}{l}\text { The larger } \\
\text { windows } \\
\text { are located } \\
\text { on the } \\
\text { South } \\
\text { facade, no } \\
\text { windows } \\
\text { were place } \\
\text { on the } \\
\text { North } \\
\text { facade }\end{array}$ & $\begin{array}{l}\text { Orientated to } \\
\text { allow light to } \\
\text { enter the } \\
\text { building on } \\
\text { the } \\
\text { East/West } \\
\text { facades }\end{array}$ & $\begin{array}{l}\text { The larger } \\
\text { windows } \\
\text { are located } \\
\text { on the } \\
\text { South } \\
\text { facade, no } \\
\text { windows } \\
\text { were place } \\
\text { on the } \\
\text { North } \\
\text { facade }\end{array}$ & $\begin{array}{l}\text { Orientated to } \\
\text { allow light to } \\
\text { enter the } \\
\text { building on } \\
\text { the } \\
\text { East/West } \\
\text { facades }\end{array}$ & $\begin{array}{l}\text { There are } \\
\text { no } \\
\text { openings } \\
\text { besides the } \\
\text { main } \\
\text { entrance }\end{array}$ & $\begin{array}{l}\text { No } \\
\text { openings } \\
\text { found on } \\
\text { the South } \\
\text { facade to } \\
\text { eliminate } \\
\text { solar gain }\end{array}$ \\
\hline $\begin{array}{l}\text { Heat } \\
\text { Distribution }\end{array}$ & $\begin{array}{l}\text { Wood } \\
\text { stove; Saw } \\
\text { dust mixed } \\
\text { with } \\
\text { agricultural } \\
\text { lime acted } \\
\text { as } \\
\text { insulation; } \\
\text { Hayloft } \\
\text { above the } \\
\text { cow shed } \\
\text { also acted } \\
\text { as } \\
\text { insulation }\end{array}$ & $\begin{array}{l}\text { Heat from the } \\
\text { animals; Saw } \\
\text { dust mixed } \\
\text { with } \\
\text { agricultural } \\
\text { lime }\end{array}$ & $\begin{array}{l}\text { Wood } \\
\text { stove; Saw } \\
\text { dust mixed } \\
\text { with } \\
\text { agricultural } \\
\text { lime }\end{array}$ & \begin{tabular}{|l|} 
Heat \\
produced \\
from the \\
animals; \\
Hayloft above \\
the cow shed \\
acted as \\
insulation
\end{tabular} & N/A & \begin{tabular}{|l|} 
Saw dust \\
was placed \\
over the ice \\
blocks to \\
prevent \\
them from \\
melting \\
acting as \\
insulation
\end{tabular} \\
\hline
\end{tabular}




\begin{tabular}{|c|c|c|c|c|c|c|}
\hline Planning & $\begin{array}{l}\text { Located } \\
\text { close to the } \\
\text { main road } \\
\text { and barn to } \\
\text { diminish } \\
\text { walking } \\
\text { distances }\end{array}$ & $\begin{array}{l}\text { Built into the } \\
\text { hillside to } \\
\text { facilitate } \\
\text { access to the } \\
\text { hayloft }\end{array}$ & $\begin{array}{l}\text { Located } \\
\text { near the } \\
\text { Veuve } \\
\text { River for } \\
\text { easy } \\
\text { access to } \\
\text { water }\end{array}$ & $\begin{array}{l}\text { Located near } \\
\text { the Veuve } \\
\text { River for } \\
\text { easy access } \\
\text { to water }\end{array}$ & \begin{tabular}{|l|} 
Framed on \\
the exterior \\
to facilitate \\
grain \\
storage
\end{tabular} & $\begin{array}{l}\text { Located } \\
\text { near water, } \\
\text { and the } \\
\text { barns to } \\
\text { diminish } \\
\text { distance } \\
\text { needed to } \\
\text { move the } \\
\text { ice blocks }\end{array}$ \\
\hline Light & $\begin{array}{l}\text { Windows } \\
\text { located to } \\
\text { facilitate } \\
\text { light } \\
\text { penetration } \\
\text { when most } \\
\text { needed }\end{array}$ & $\begin{array}{l}\text { Windows } \\
\text { orientated on } \\
\text { the East and } \\
\text { West walls to } \\
\text { provide light } \\
\text { during the } \\
\text { milking of the } \\
\text { cows (dawn } \\
\text { and dusk) }\end{array}$ & $\begin{array}{l}\text { Windows } \\
\text { located to } \\
\text { facilitate } \\
\text { light } \\
\text { penetration } \\
\text { when most } \\
\text { needed }\end{array}$ & $\begin{array}{l}\text { Windows } \\
\text { orientated on } \\
\text { the East and } \\
\text { West walls to } \\
\text { provide light } \\
\text { during the } \\
\text { milking of the } \\
\text { cows (dawn } \\
\text { and dusk) }\end{array}$ & $N / A$ & N/A \\
\hline Materials & $\begin{array}{l}\text { Local } \\
\text { materials - } \\
\text { red pine, } \\
\text { stone } \\
\text { foundation, } \\
\text { brick } \\
\text { siding, tin }\end{array}$ & $\begin{array}{l}\text { Local } \\
\text { materials - } \\
\text { red pine, tin } \\
\text { roof, stone } \\
\text { foundation }\end{array}$ & $\begin{array}{l}\text { Local } \\
\text { materials - } \\
\text { red/white } \\
\text { pine, tin } \\
\text { roof, } \\
\text { linoleum, } \\
\text { brick } \\
\text { siding, } \\
\text { stone } \\
\text { foundation }\end{array}$ & $\begin{array}{l}\text { Local } \\
\text { materials - } \\
\text { red pine, tin } \\
\text { roof, stone } \\
\text { foundation }\end{array}$ & \begin{tabular}{|l|} 
Local \\
materials - \\
red pine, tin \\
roof
\end{tabular} & $\begin{array}{l}\text { Local } \\
\text { materials - } \\
\text { wooden } \\
\text { logs, tin } \\
\text { roof }\end{array}$ \\
\hline Culture & $\begin{array}{l}\text { Built by } \\
\text { family } \\
\text { members }\end{array}$ & $\begin{array}{l}\text { Built by } \\
\text { family } \\
\text { members, } \\
\text { following the } \\
\text { Dutch Style - } \\
\text { common in } \\
\text { the area }\end{array}$ & $\begin{array}{l}\text { Built by } \\
\text { employing } \\
\text { a 'raising } \\
\text { bee' }\end{array}$ & $\begin{array}{l}\text { Built by } \\
\text { employing a } \\
\text { 'raising bee,' } \\
\text { following the } \\
\text { Dutch Style - } \\
\text { common in } \\
\text { the area } \\
\text { Tenon and } \\
\text { joint } \\
\text { construction }\end{array}$ & $\begin{array}{l}\text { Built by the } \\
\text { family }\end{array}$ & $\begin{array}{l}\text { Built by the } \\
\text { family }\end{array}$ \\
\hline
\end{tabular}

\section{The Importance of a New Approach}

"We subsist on myths about nature, deny its reality, and finally, squander opportunities to enhance our relationship to it. Could it be we have a deep ambivalence toward nature and an uncertainty about how to reconcile ourselves to our 
natural surroundings?"35 It would appear that the latter rings true. We have forgotten the lessons of the past, and now scramble to rediscover how to re-create the balance that once was there. It is absurd to ignore the environment, since it is the world we live in. Northrop Frye stated:

"A culture which is the expression of a specific community is in contrast to a mass culture which tends towards uniformity rather than unity, and towards obliterating of the specific and distinctive... Every part of Canada is shut off by its geography. Everywhere... we find solitudes touching solitudes: every part of Canada has strong separatist feelings because every part of it is in fact a separation." 36

It is not enough to integrate the environment into architecture, one must also reconcile culture and tradition into the built form. It is not necessary to mimic past models, but to carefully examine what aspects of a culture are important and redefine these in architecture. Grant eloquently stated: "My lament is not based on philosophy but on tradition. If one cannot be sure about the answer to the most important questions, then tradition is the best basis for the practical life." ${ }^{\prime 37}$ Architecture is not created for objects it is created for people. Ultimately, if a person cannot utilize a building or relate to it, then what is the point? "Similarly the architect who wishes to reinforce the psyche of the people he serves rather than change (improve, educate) it, should try to search out those design elements that are saturated

\footnotetext{
${ }^{35}$ Kapelos 11.

${ }^{36}$ Northrop Frye, Toronto Globe and Mail 18 Oct. 1977.

${ }^{37}$ Grant 106.
} 
with this sort of cultural meaning. In giving people what architects think they ought to like, they often don't remember why what people like is bad." 38

\section{An Examination of Design Practices}

In recent years, more and more Canadian architects seem to look towards climate and environmental issues as a basis for designing architecture. "For many designers an exploration of a site's specific character, community conditions, the history of its people, local customs, climate, and culture, provides a way to 'ground' architecture, to give it meaning and substance. The corollary to this is that grounded architecture and design foster a sense of community, a sense of belonging, and a sense of identity." ${ }^{39}$ It would appear that many Canadian architects are weary of foreign models, which address little of this country. "Today, we know that a single layer of insulation can impact energy efficiency to a greater extent than landscape interventions. However, in the mediating zone between indoor and outdoor (or between internal zones of a building), comfort and delight can be achieved through the subtle manipulation of soil, plants and water." 40 As a result, a series of new approaches and new practices are taking place. More literature is now available on the subject and the importance of these changes is strongly being advocated. For example, Jorma Mänty and Norman Pressman authors of Cities Designed For Winter, suggest guidelines for coping in cold climates. Here are but a few suggestions they mention.

${ }^{38}$ Anthony Jackson, The Democratization of Canadian Architecture (Halifax: Tech-Press, 1978) 18.

\footnotetext{
${ }^{39}$ Kapelos 146.

${ }^{40}$ Kesik 35.
} 
"Approaches to Coping with Cold

1. Do not overprotect man from nature

This assumes that man must learn to co-exist happily with nature. If offered an undue amount of protection from the harsh elements, humans living in cold climates will become too docile and sensitive as opposed to becoming adaptive, sturdy and able to conquer nature's inconveniences without relying heavily on technology. ${ }^{, 41}$

"Ignoring sunlight seems to originate in industrial society - a civilization that has declared its independence from the landscape - in part because fossil fuels afford reliable heat, even on cloudy days, rendering the sun obsolescent as a heat source for human habitation.

On a different note, architects like Pierre Thibault have started to explore and discover the possibilities for a regional architectural style through various installations that deal specifically with the climate and the environment. An example of Thibault's work is Winter Gardens (Fig. 29,30). This is an installation in which various lights and objects were placed on a frozen lake. The effects were phenomenal, creating an illusion of density.

\footnotetext{
${ }^{41}$ Mänty 23.

${ }^{42}$ Strub 41.
} 


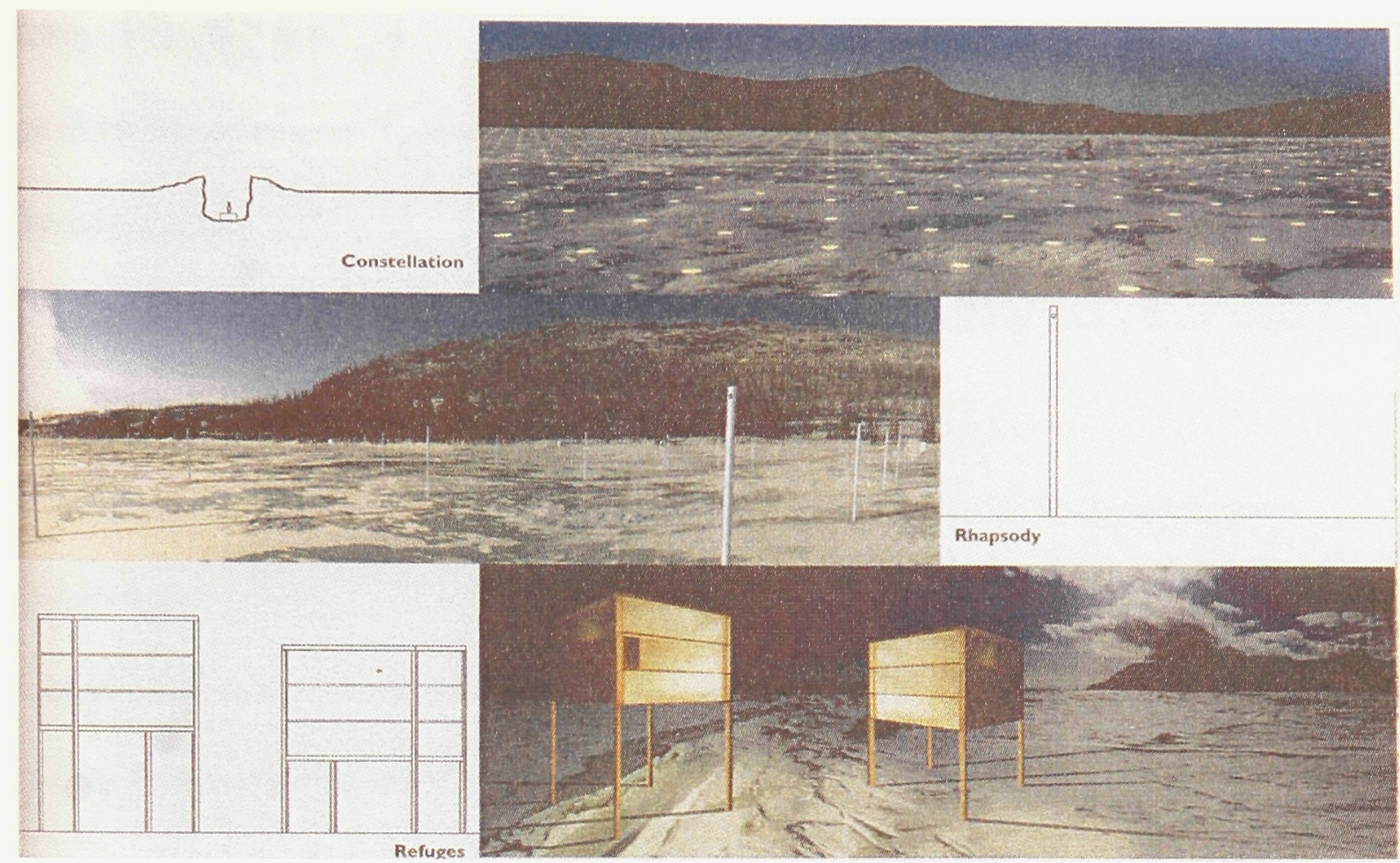

Figure 29 - Winter Gardens

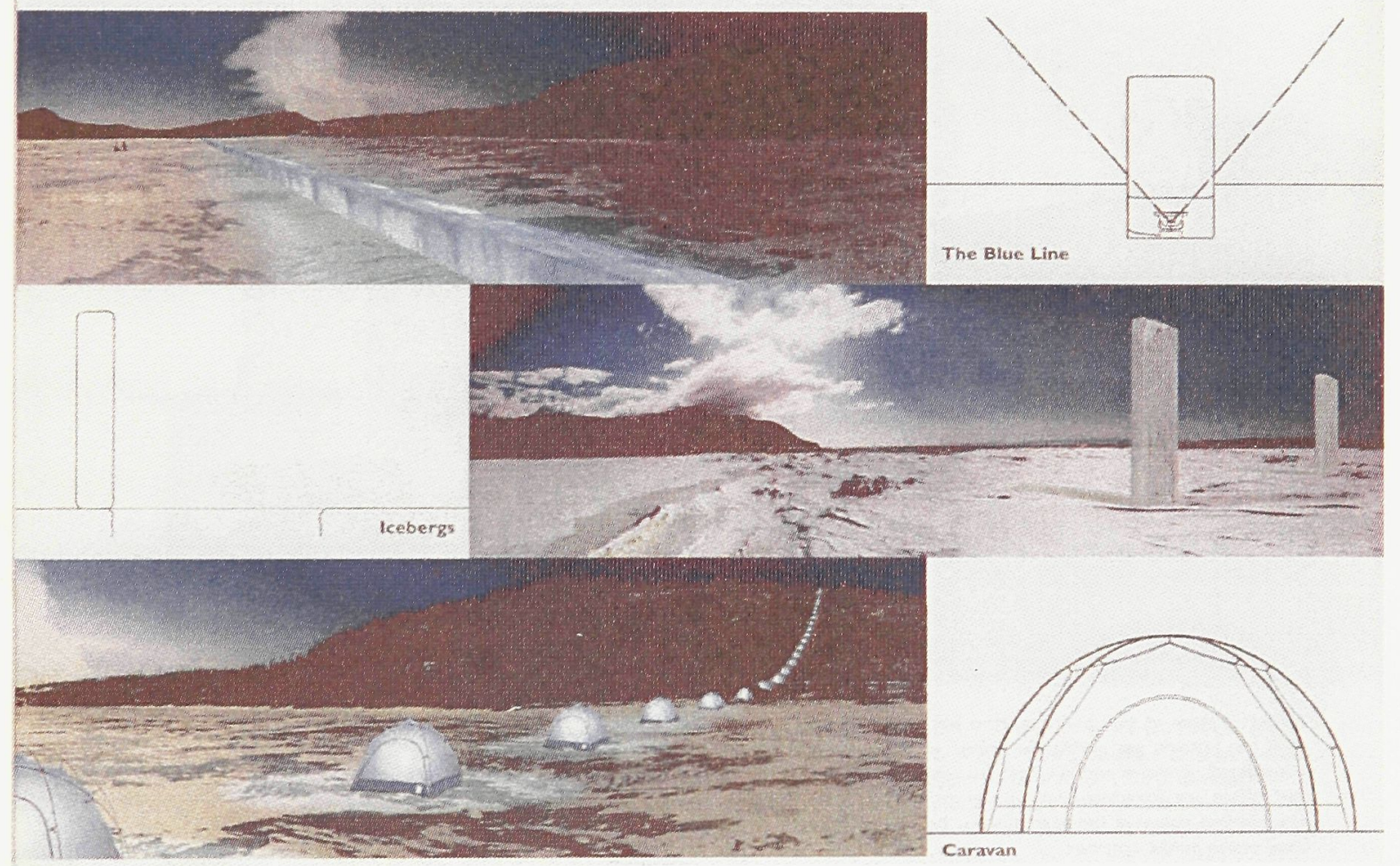

Figure 30 - Winter Gardens

Pierre Thibault utilizes the installations he creates to inform and guide his architecture. What is learned during these investigations is then reflected in the built 
form. His goal is to understand the environment which surrounds his work and then push those notions as far as possible by finding and creating innovative ways of integrating the natural environment within his architecture.

As a Canadian architect practicing in the prairies, Barry Johns demonstrates a keen awareness of climatic conditions in his work. By dealing with issues of efficiency, durability, greater use of daylight, sustainability, climate, and culture, Barry Johns manages to recapture meaning and create an architectural style unique to Canada's prairies. An interesting aspect of Johns' work is the collaboration of community members in the design process.

"Striving to make design a public activity, not a private process contained within the domain of the profession, he [Barry Johns] has empowered individuals and communities. It is a move which has helped to make architecture a focus of concern and benefit in places where people are still made aware of the rigours of life by the extremes of climate and distance that predominate in their daily lives. $" 43$

By doing so, communities are given the chance to participate in the design process, permitting for a better understanding of the work completed. What better way to integrate culture in the design process? With community involvement, the architecture is influenced by a group of individuals from various backgrounds, practicing various professions, as opposed to a design from a single individual. In this sense, the role of the architect changes somewhat from the overall designer to a mediator and facilitator. This notion of collaboration is not a new approach, but one,

${ }^{43}$ Documents in Canadian Architecture, Barry Johns Architects (Halifax: Tuns Press, 2000) 
which has dissolved over the years, but is likely to resurface in the near future.

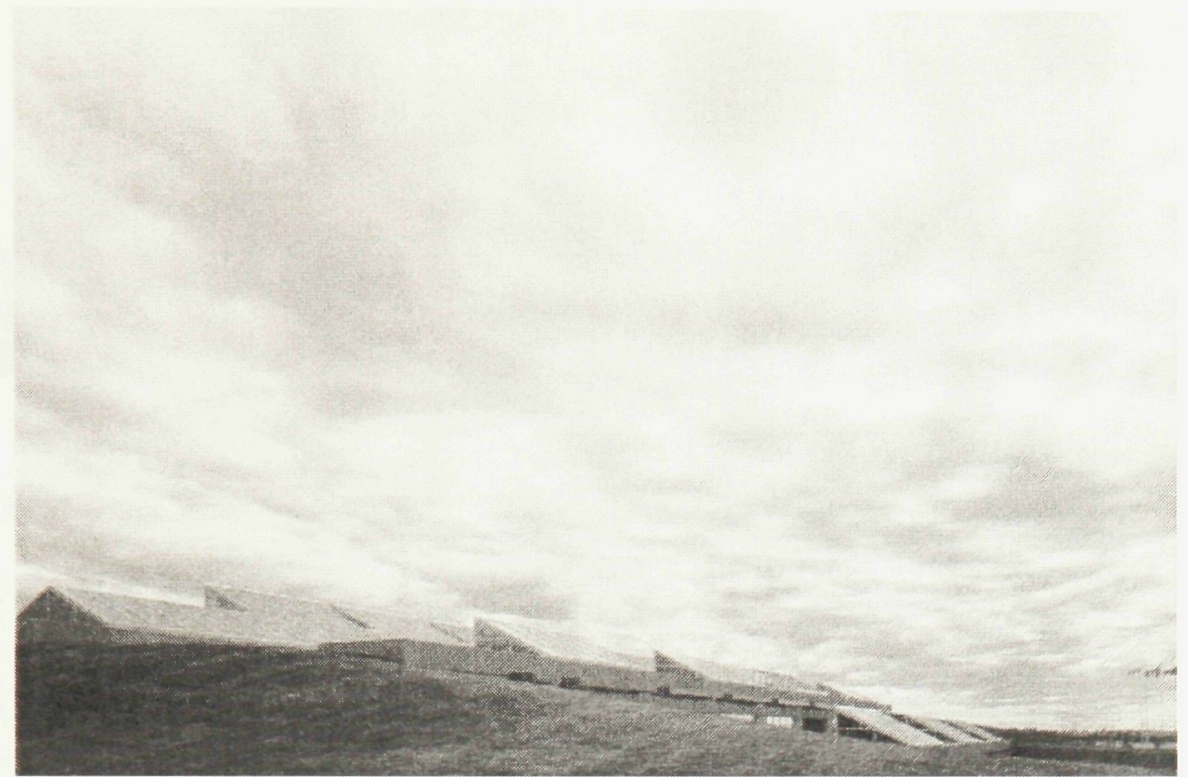

Figure 31 - Advanced Training Centre, Edmonton, Alberta

An example of Barry Johns' architecture is the Advanced Training Centre in Edmonton, Alberta built from 1986-1988. The Advanced Training Centre is extremely integrated into the site (Fig. 31). "By carving a ravine out of the ground, sculpting the excavated material and covering the roof with grass, the building is integrated with the site." ${ }^{\prime 4}$ The site and the building become inseparable. By placing the building in the earth, there are substantial savings with regards to heating and cooling costs. "The Natural insulating capability of the earth shelters the building and significantly reduces the heating requirements. Cool temperatures are sustained in summer due to the relatively constant ground temperature three metres below the surface. ${ }^{45}$ The earth also acts as an envelope protecting the building from the elements (Fig. 32).

\footnotetext{
${ }^{44}$ Documents in Canadian Architecture 21.

${ }^{45}$ Documents in Canadian Architecture 26.
} 


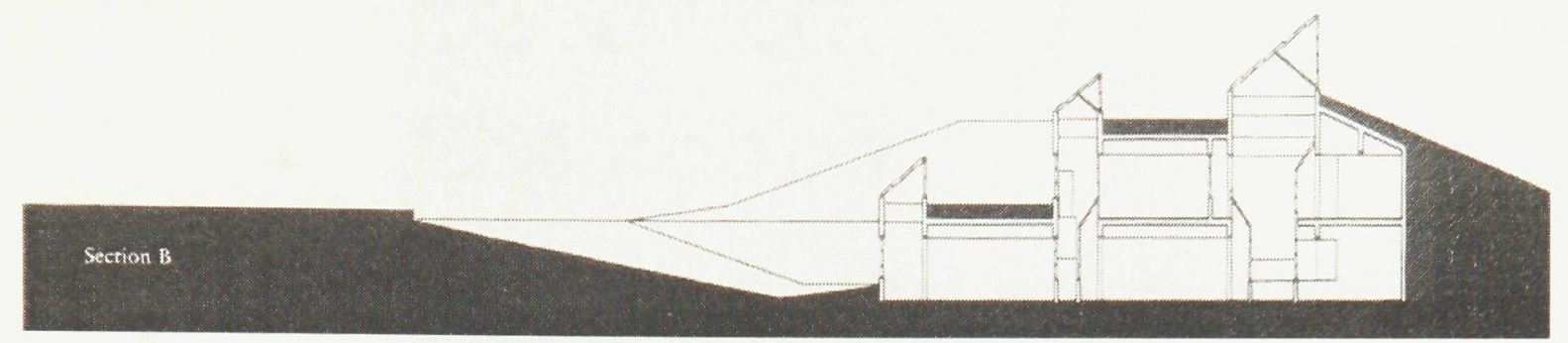

Figure 32 - Cross Section of the Advanced Training Centre

This particular project consists of common meeting and social spaces, such as the library and the secretarial resources. There is a very strong sense of community felt within the building.

The following is a critique by Brian Allsopp on this particular project.

"The new Advanced Technology Centre in Edmonton, although not on a hill, certainly follows the spirit of this idea, that architecture and land form can merge. It is a piece of architecture about the prairie, about the meeting of sky and earth, about horizon. It is also a very Canadian investigation of our relationship to land and region." 46

Allsopp then goes on to state a number of pros and cons with regards to the building, but closes his remark by stating: "This is the best 'Canadian' building about region in a long time, in the tradition of Thom, Erickson, and Myers." ${ }^{47}$ Although some of the ideas expressed in this building did not work as initially planned, the overall building still functions architecturally and economically. By recognizing issues of sustainability, climate, and culture, the building speaks very strongly about a regional identity.

\footnotetext{
${ }^{46}$ Brian Allsopp, "Edmonton Advanced Technology Centre," Canadian Architect 34.4
} (1989): 26.

${ }^{47}$ Allsopp 30. 


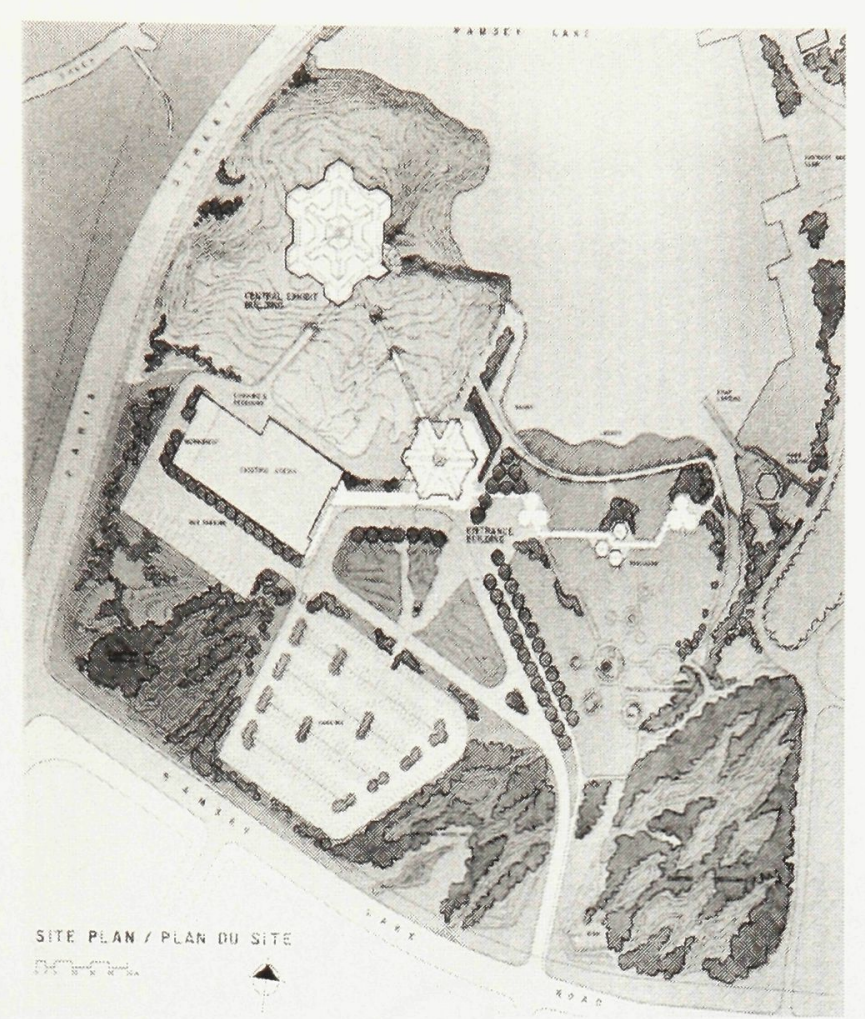

Figure 33 - Site Plan, Science North, Sudbury, Ontario

The final work examined is Moriyama and Teshima's Science North building in Sudbury. This project is a clear demonstration of the impact architecture can have if one combines culture and the environment with the built form.

"Moriyama and Teshima's Science North uses the snowflake as a metaphor for an important regional museum. The form metaphorically symbolized by an ice crystal and transformed, has symbolic meaning: representative of Sudbury's winter experience of nature, a strong part of life in the north. But Science North is not a one-liner - the project is also about geology. Below ground, exposed rocks and minerals describe another aspect of the precise organic structure of nature. The interplay between form and experience is a subtle, yet powerful expression of the importance of climate and natural resources in the culture of northern Ontario. ${ }^{48}$ (Fig. 33) 
Since Science North was built in Sudbury, founded in great part due to mining, it was only reasonable to express this culture and heritage in the museum. If this

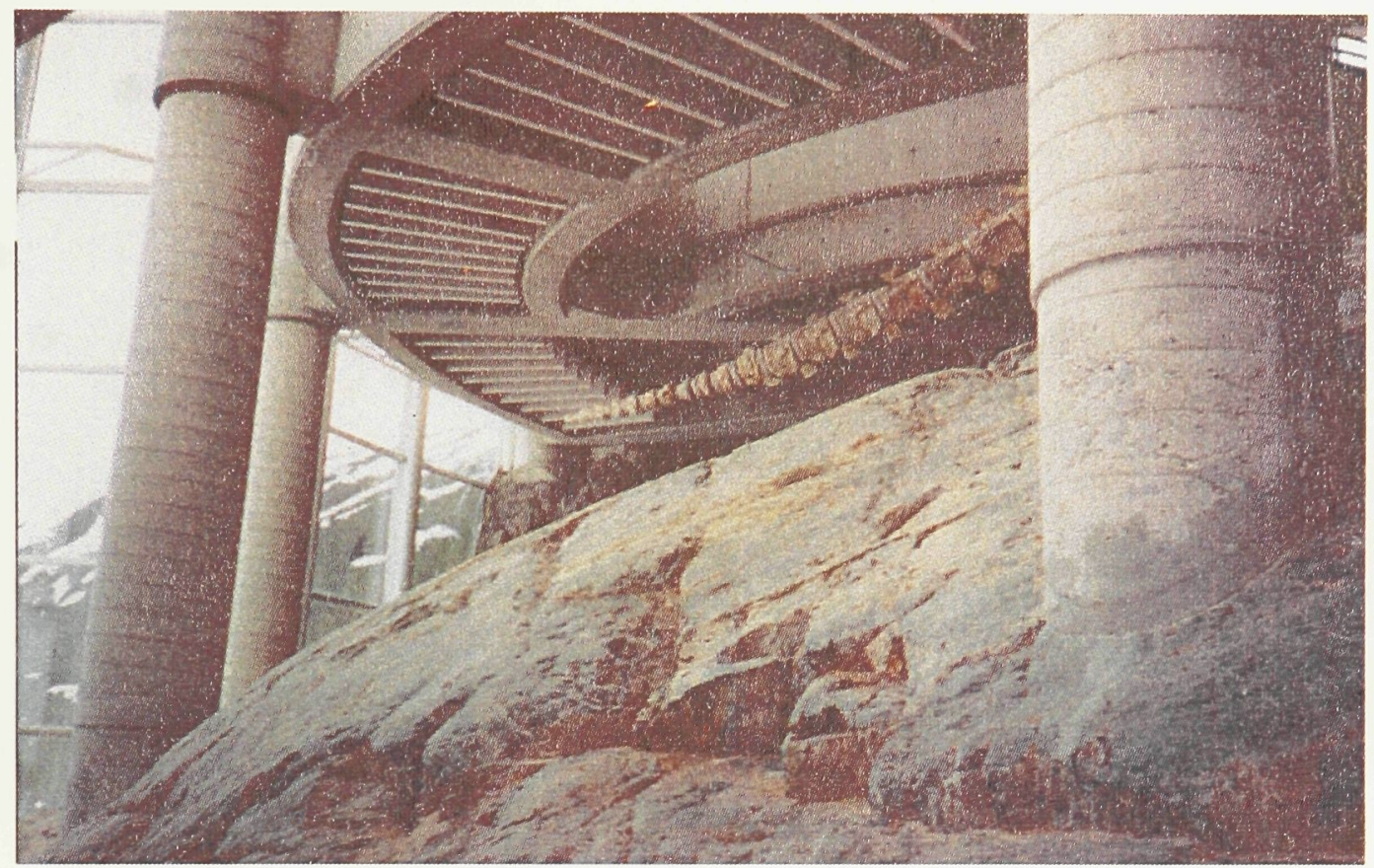

Figure 34 - Science North, Sudbury, Ontario

museum had only expressed the metaphor of the snowflake, its final outcome would have been somewhat disappointing. Since the architects took the time to truly understand the components of the site, this project became an expression of geology rather than mere metaphor. When walking through the museum, one is aware of the various components of nature; i.e. bed rock, ground, sky, etc. (Fig. 34). The earth's many facets are revealed through various levels in the museum. The building functions didactically, explaining the varying levels of strata as well as innovative ways of utilizing nature. For example, there is a bridge leading from Science North to Ramsey Lake. When approaching the lake, one is under the impression that the bridge is floating above the water. Upon closer inspection, one notices that it is attached to the rock bed through a series of legs and anchors. This bridge emphasizes the strength and stability of the bedrock, while also commenting on the unpredictability of the water. (Fig. 35, 36) 


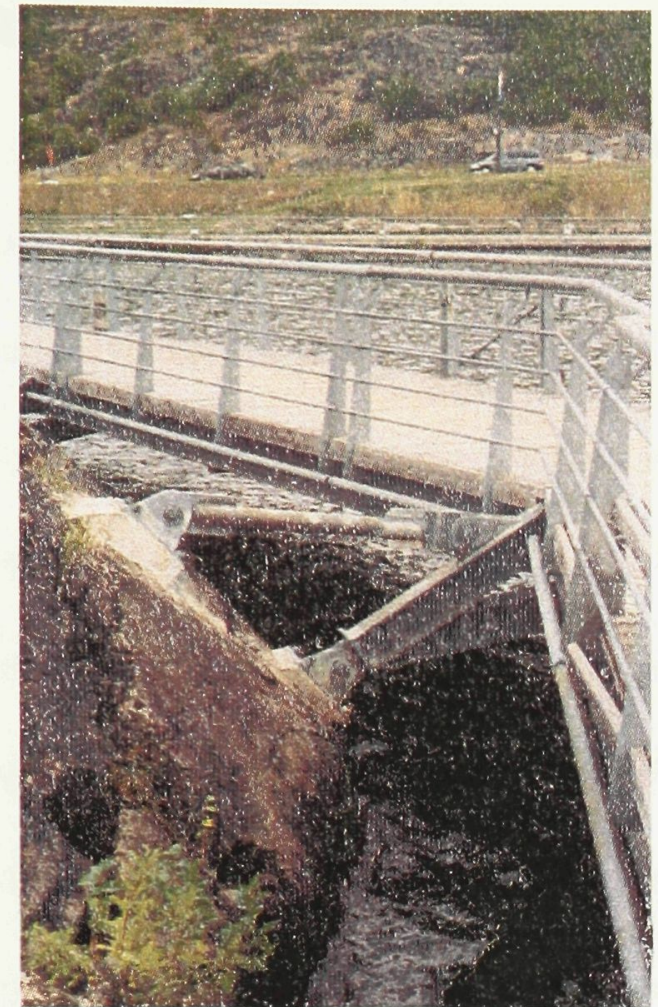

Figure 35 - Bridge on Ramsey Lake, Sudbury, Ontario

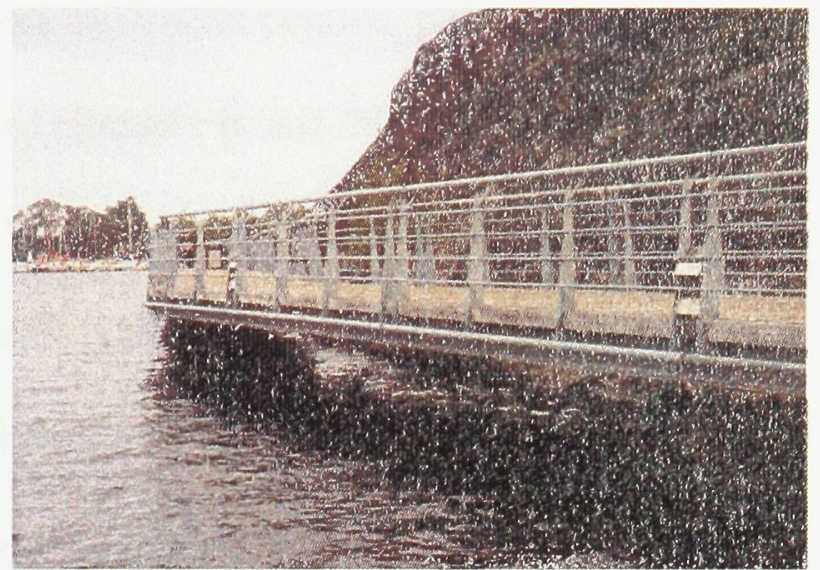

Figure 36 - Bridge on Ramsey Lake

Science North comments on the pride and respect with which, the city holds its natural resources. This architecture embodies what Northern Ontario is really about. 


\section{Design Project}

Having been raised in Northern Ontario, it only seemed appropriate to conduct a project based on Northern architecture. Growing up in a small rural community, one understands the hardships of assimilation and technological advancements. Although culture and tradition have a strong presence in smaller centres, philosophies from larger centres are a continual threat toward change. It was this notion that prompted my desire to enter into a thesis based on these personal and important issues. As previously illustrated, the focus of this work is the environment and technology, and their influence on Northern Ontarian architecture. The personal application of this project is to establish a method or process of design, which can inform and guide future designs over the course of my career.

In order to validate the theoretical research presented, an architectural project was conceived and a design theory was tested with an 'as-built' form. After extensive examination of the community of Verner, Ontario, a site in that town was chosen. The program consists of a residential dwelling for a single man.

Site

The property chosen for this project is approximately one hundred and twenty acres of land divided into three components: a field, which is currently utilized to cultivate hay or wheat, a wooded area, and a marshland at the rear of the property. The field component is relatively flat, whereas the wooded area is on a hillside. As seen from Figure 38, or from the aerial photo below (Fig. 37), the properties in this area are divided into long narrow strips (North/South) allowing for access to Hwy 17 
as well as access to the waterways at the rear of the properties.

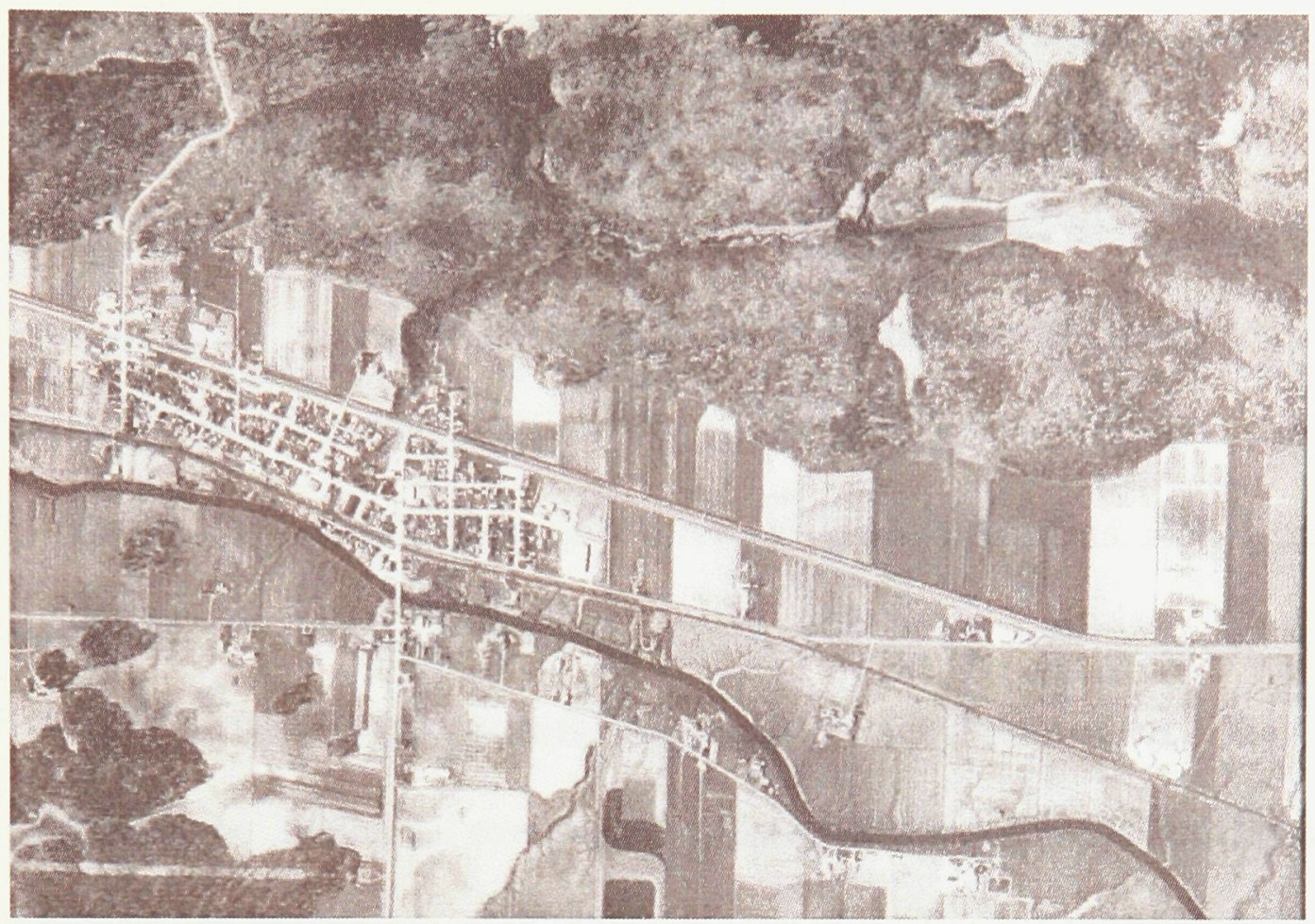

Figure 37-Aerial view of Verner taken in the 1980's.

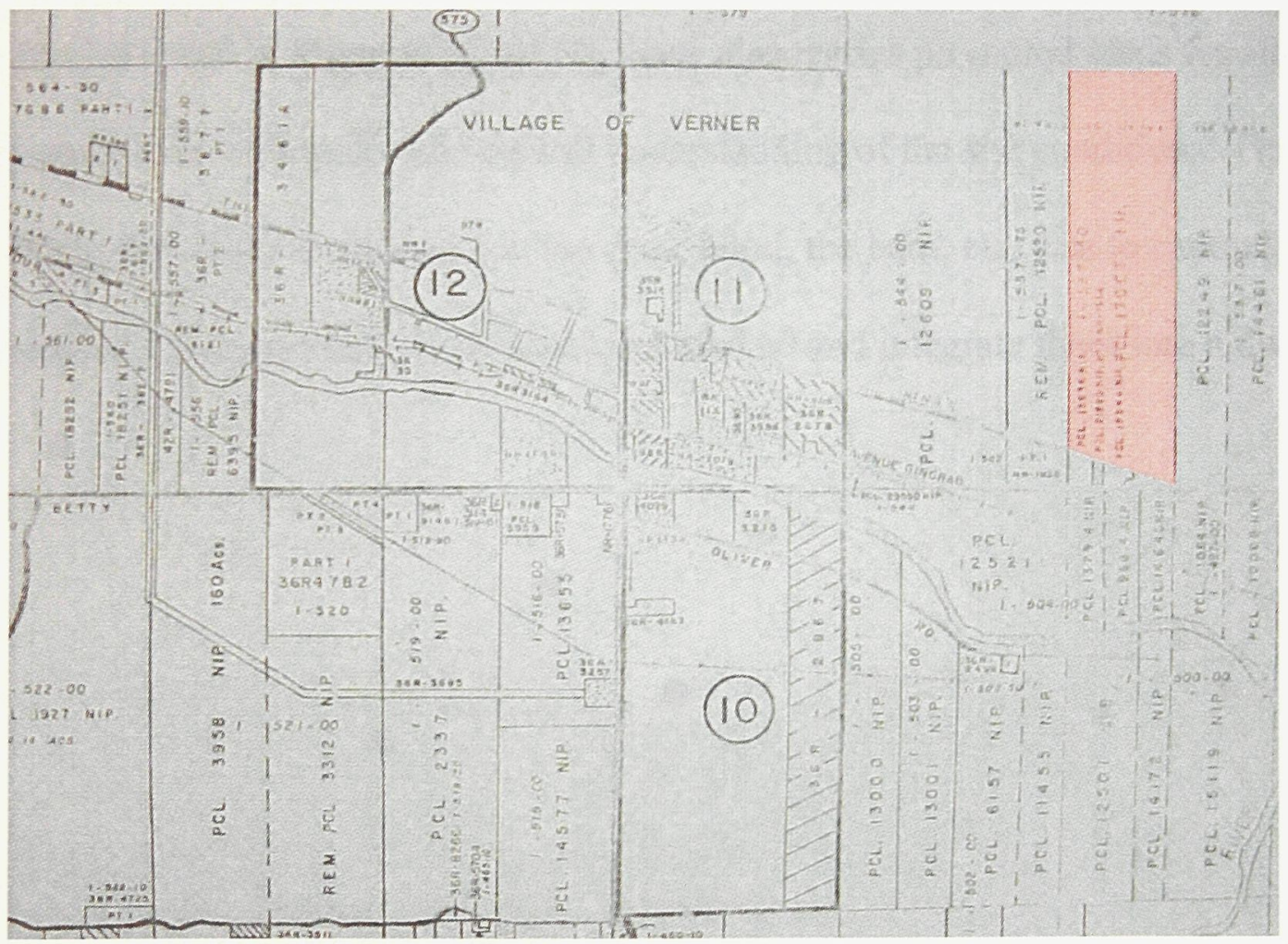

Figure 38 - Lots and concession division for the village of Vemer 


\section{Modes of Investigations}

As previously discussed, this research began with the examination of ephemeral and non-ephemeral structures. The structures chosen for study demonstrated various levels of integration within the environment. From the initial research, four structures were chosen for further examination. These included the duck blind, Science North, the tree house, and the barn. Each of these was chosen because of their specific response to a site condition: marshland, rock, field, and woodland.

A method of deconstruction was used to study the structures. The examination of individual components allowed for the deconstruction of each structure and the identification of its main function. For example, the duck blind's main function, if described architecturally, was determined as framing the horizon. As illustrated in Figures 39 and 40, these discoveries prompted ideas for site installations to broaden the overall understanding of the site conditions. The intention of the structures examined, i.e. the duck blind, the barn, etc. was to capture the qualities and emotions these structures evoked and integrate them into a dwelling. 


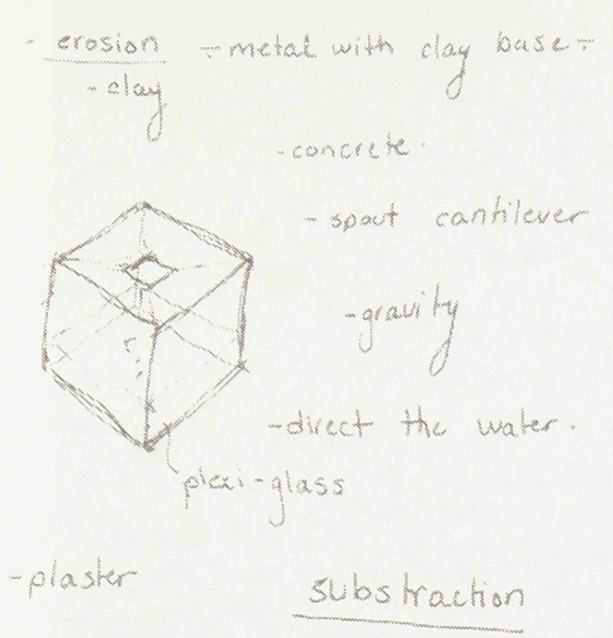

Figure 39 - Sketch

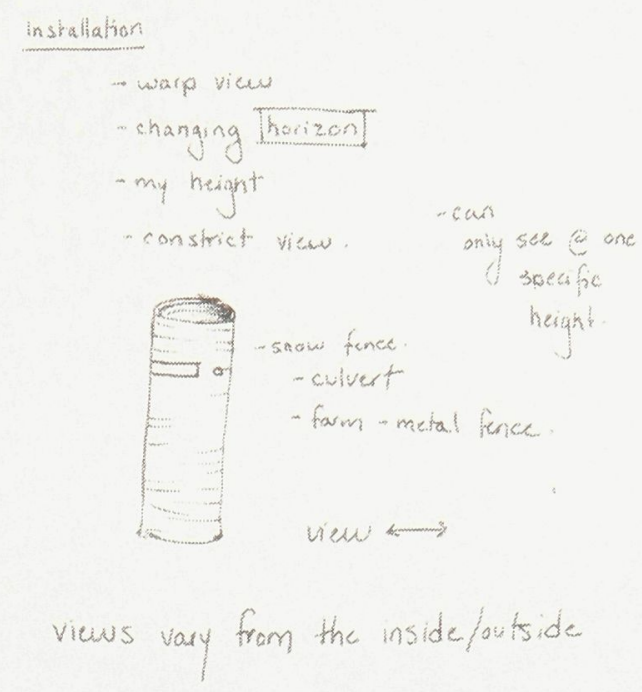

Figure 40 - Sketch

Further technical site analyses were also undertaken to fully comprehend the site. These varied from sun charts, wind patterns, water movements, and seasonal changes. It was discovered during these analyses that the examination of varying scales was needed in order to obtain a clear understanding of the entire site. From the macro level to the micro level, each component was recorded and studied. (See Figures 41-47) 


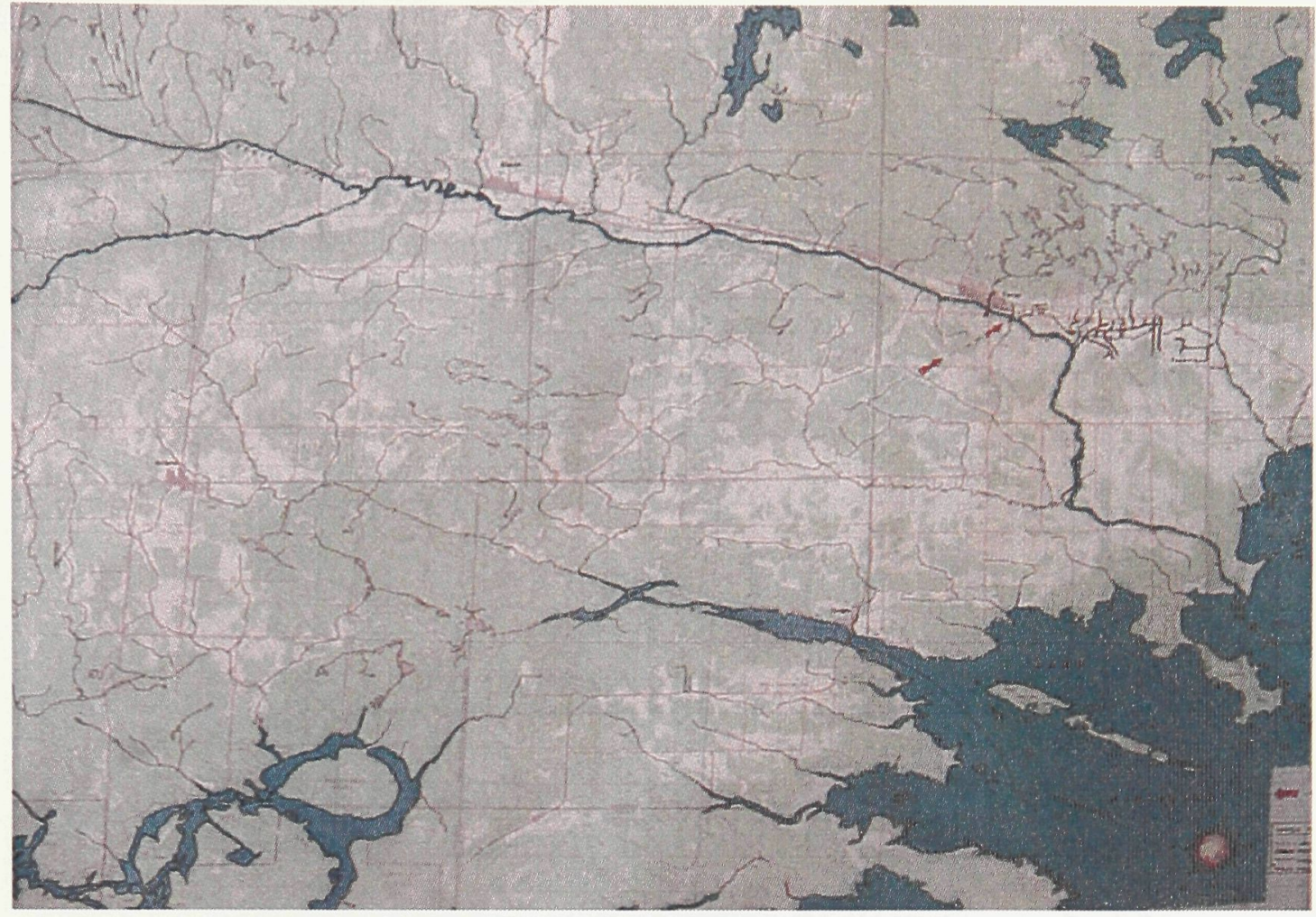

Figure 41 - Regional map demonstrating water movement and wind movement at the macro level.

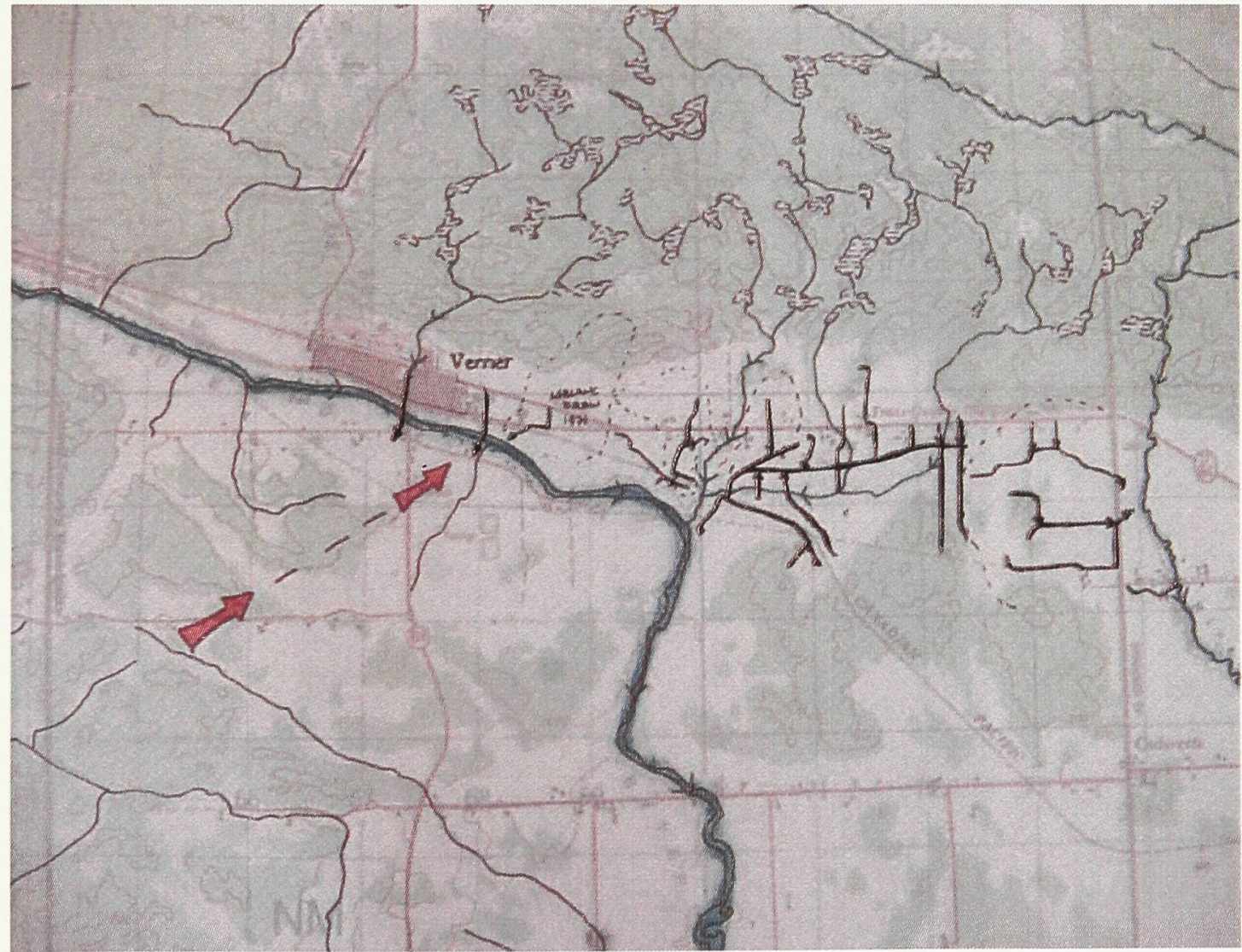

Figure 42 - Regional map demonstrating water movement and wind movement. 


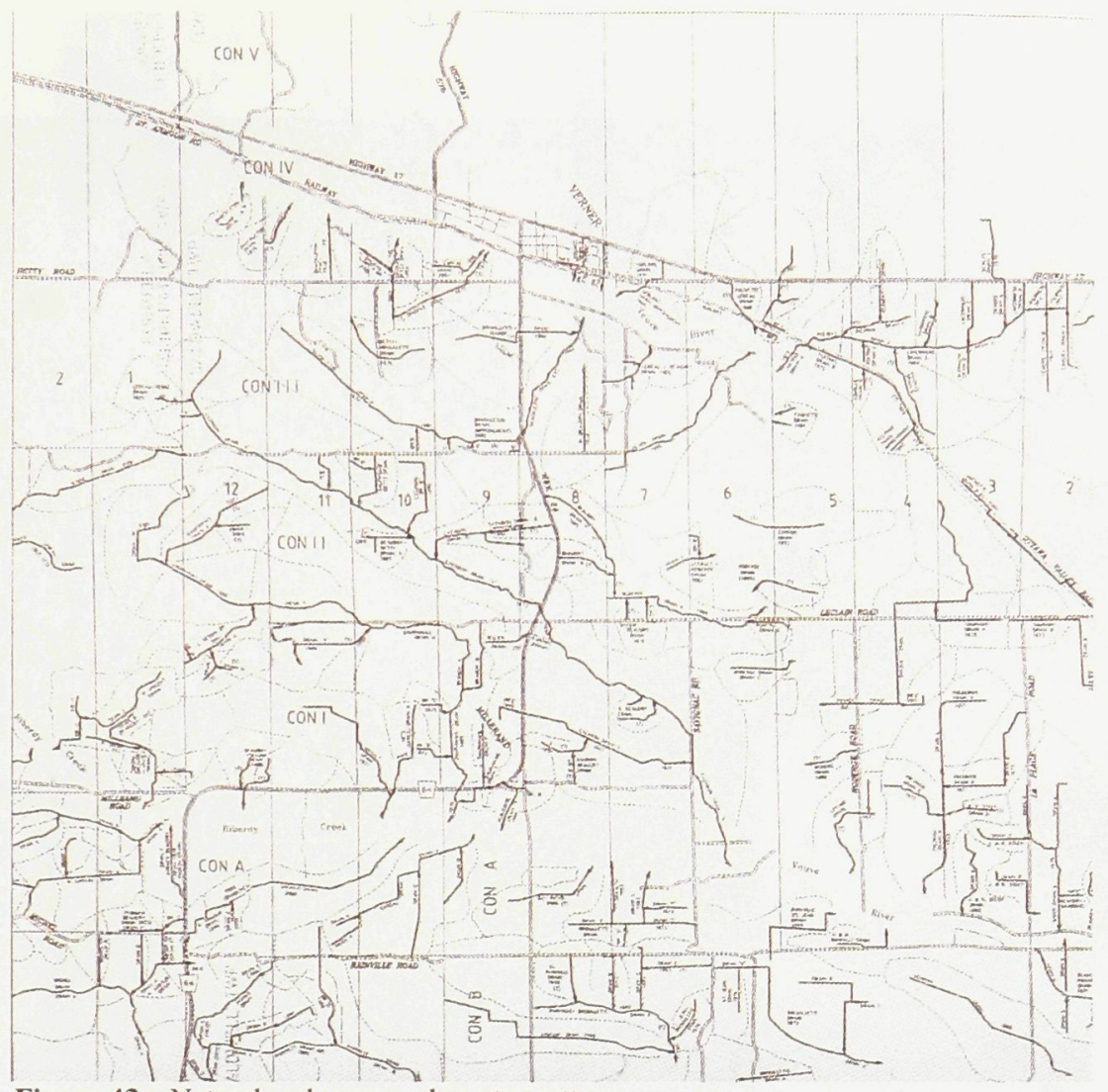

Figure 43 - Natural and man-made water patterns.

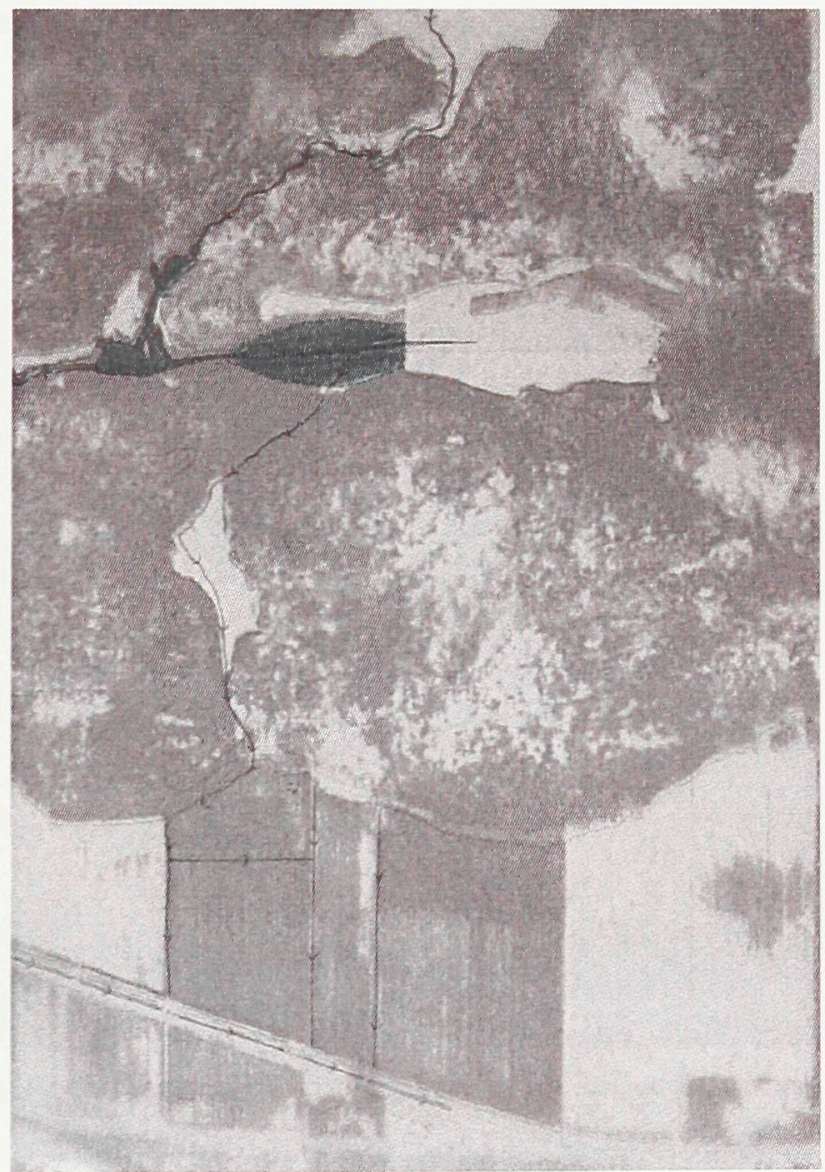

Figure 44 - Water movement found on the site 


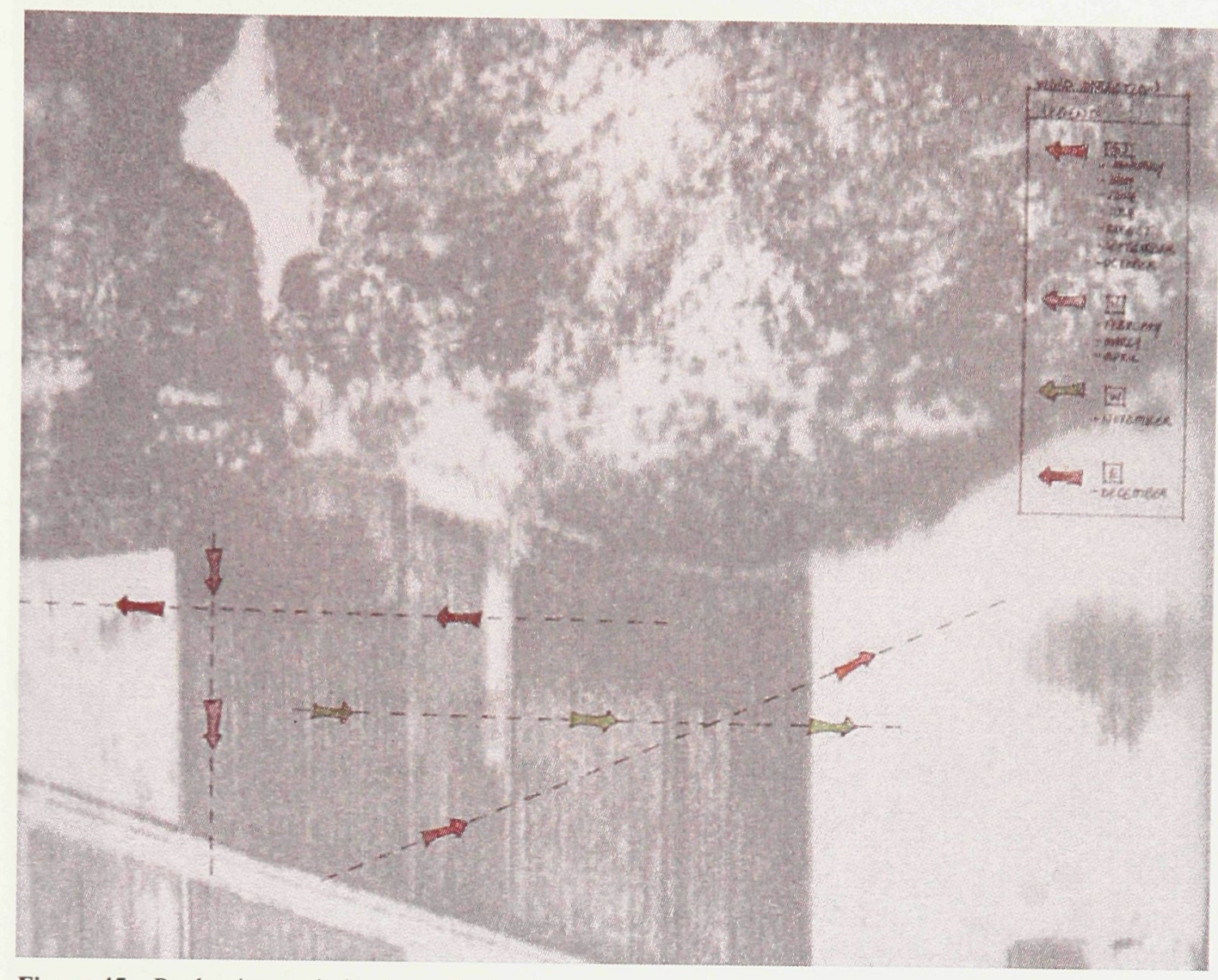

Figure 45 - Predominant wind patterns for the site.

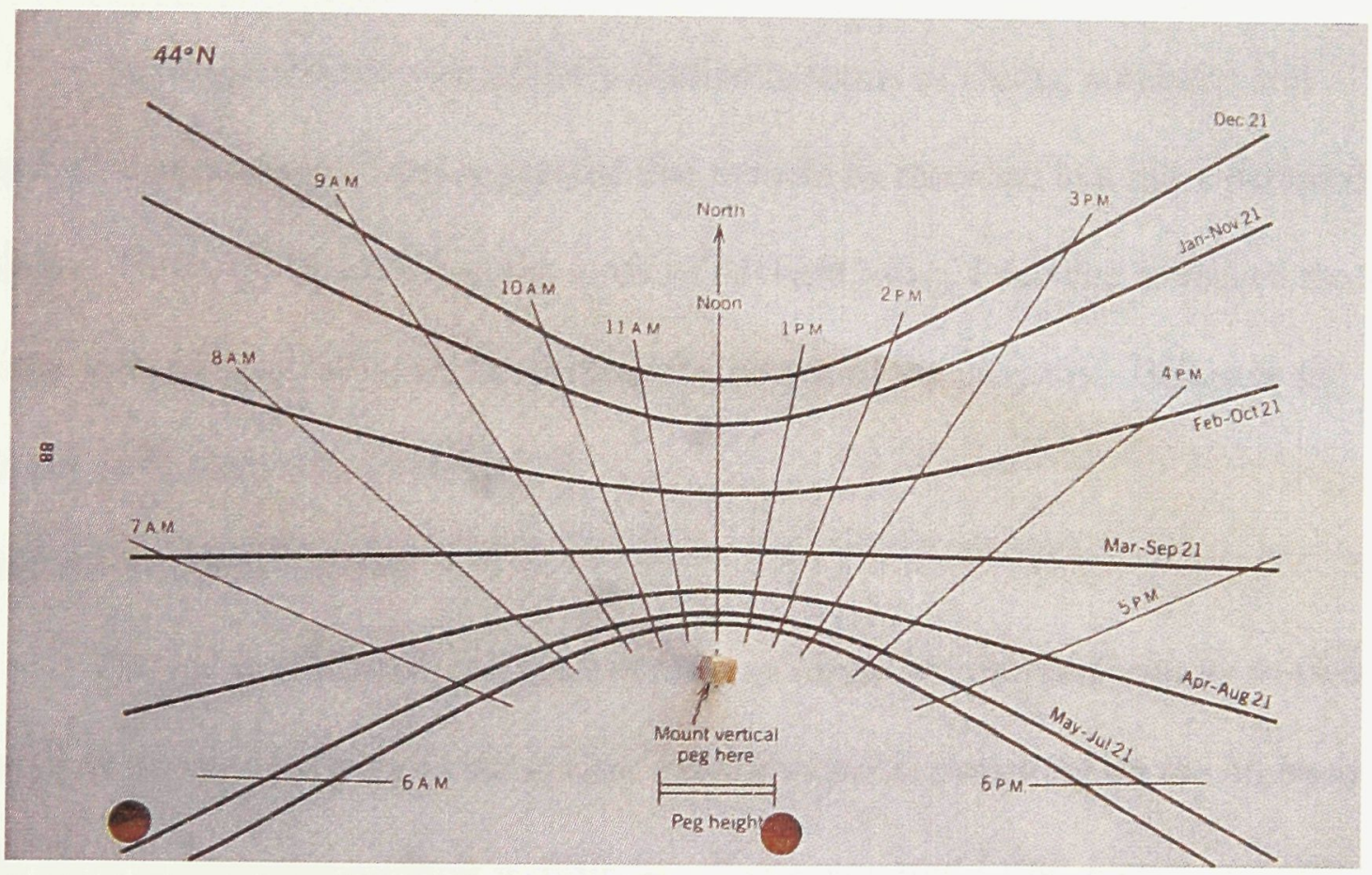

Figure 46 - Sun chart utilized to calculate sun angles on the site during various times of the year. 


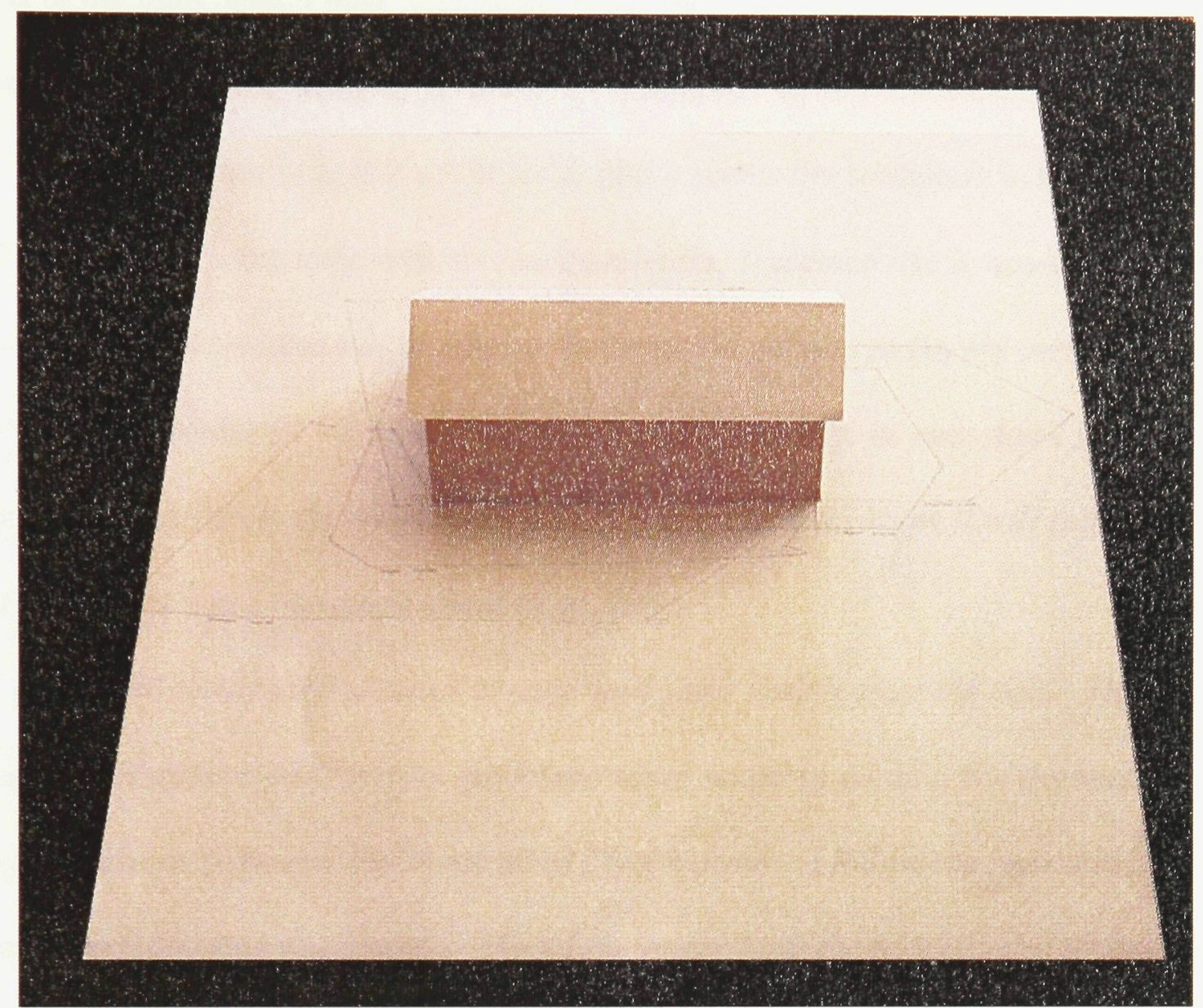

Figure 47 - A model demonstrating shadows at various times of the year for a proposed scheme

Although the site was initially studied in terms of charts, numbers, and scientific approaches it was suggested that the site be recorded in a more personal manner. Finding inspiration in the work of Richard Long, I decided to record the site in the form of a narrative while walking the length of the property. Below is an extract from one such recording.

Narrative (Jan $\left.5^{\text {th }}, 2005\right)$

The air is cold and with each breath my lungs are shocked with its freshness. I walk in silence listening to the distant hum of vehicles travelling on the highway. The snow is deep and walking is difficult. With every siep I sink deeper and deeper, amused at the idea that the snow could go past my knees. To my delight there are 
parts of the field, which have accumulated ice and I can walk as freely as I could on a cement road. It's like walking on water, or walking with snowshoes.

I am pacing the length of the field, and it seems the whiteness will engulf me. Although the crossing only took me twenty minutes, it seemed like it would never end. My eyes often avert upwards to admire the beautiful colours in the sky created by the burning sun. Although the sun is low and shinning brightly, its rays don't seem to reach me. Thankfully the wind is silent at the moment, but I know it will soon pick up. It always does when the sun is about to go down.

I head toward the wooded area to seek some shelter from the cold. The minute I am surrounded by trees the temperature seems to go up a few degrees. It probably doesn't change, but in my mind I feel warmer. I follow the snowmobile trail that my little brother has created. Here I no longer hear the hum of vehicles but the sound of running water. There isn't much water, but it travels quickly down from the marshland through the forest towards the field. I admire the ice crystals glistening in the sun surrounding the stream. Yesterday's winds blew most of the snow off the trees. I prefer them covered in snow, but the green foliage against the white background is just as beautiful.

It's time for me to leave since it will be dark soon. I linger on my way back to admire and capture the essence of the site. Its tranquility calms me, but its vastness also alarms me. I find my way to my car and return home torn between such a natural setting and the alternate setting of man's creation. (Fig. 48) 

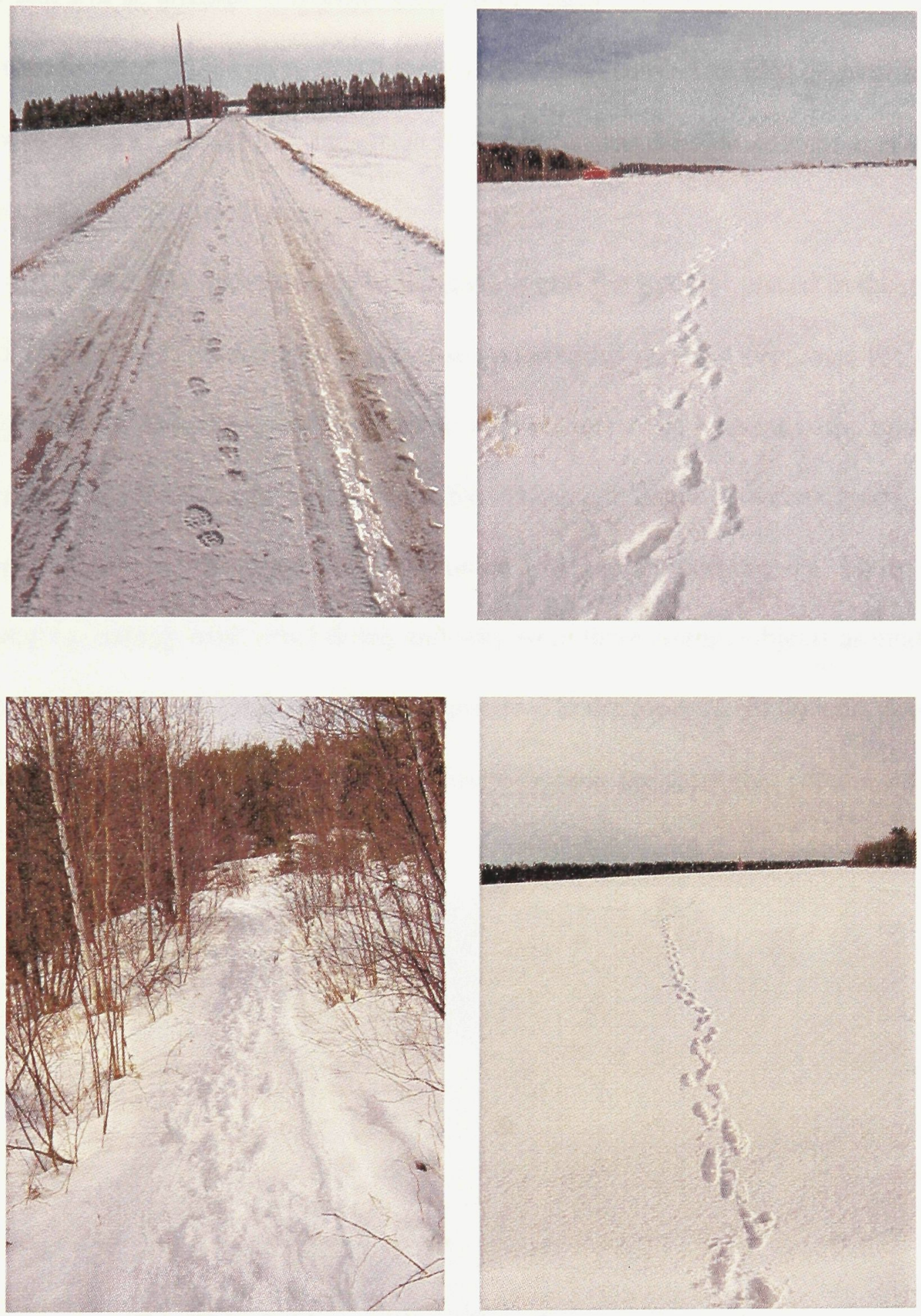

Figure 48 - Paths created by pacing the property 
Prior to developing a design on paper, a series of site installations were created in an attempt to express some of my ideas. The first series of installations were focused on breaking down pre-conceived notions. The idea of creating curiosity or even simply obtaining a reaction from people was the first attempt at re-defining a process method for the design.

The first installation was comprised of a fire hydrant placed in the centre of a field (Fig. 49). This fire hydrant caused an obvious reaction in passers-by, the question almost visible on their faces: why is there a fire hydrant in the middle of a crop field? The installation allowed for dialogue to occur between myself, and the neighbours, as well as between various members of the community. Many would stop by, asking what was I doing and why were there strange objects around? People offered comments both negative and positive to the process. In the end, it was the fact that I could engage people into discourse over the work that I found compelling.

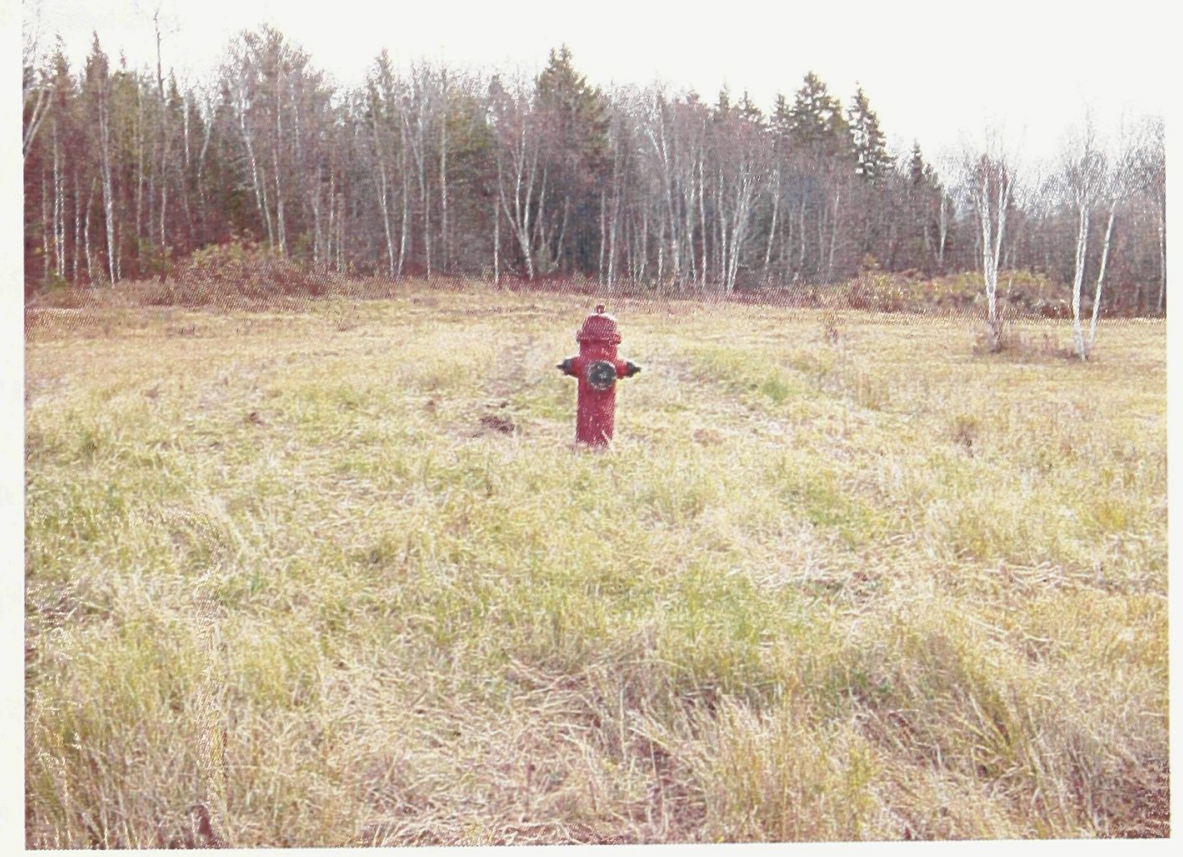

Figure 49 - Installation 
A second installation was an exterior space defined by placing doors and windows in the middle of the forest. Again, this played with the notion of creating curiosity. This installation also spoke about interior/exterior relationships (Fig. 50).

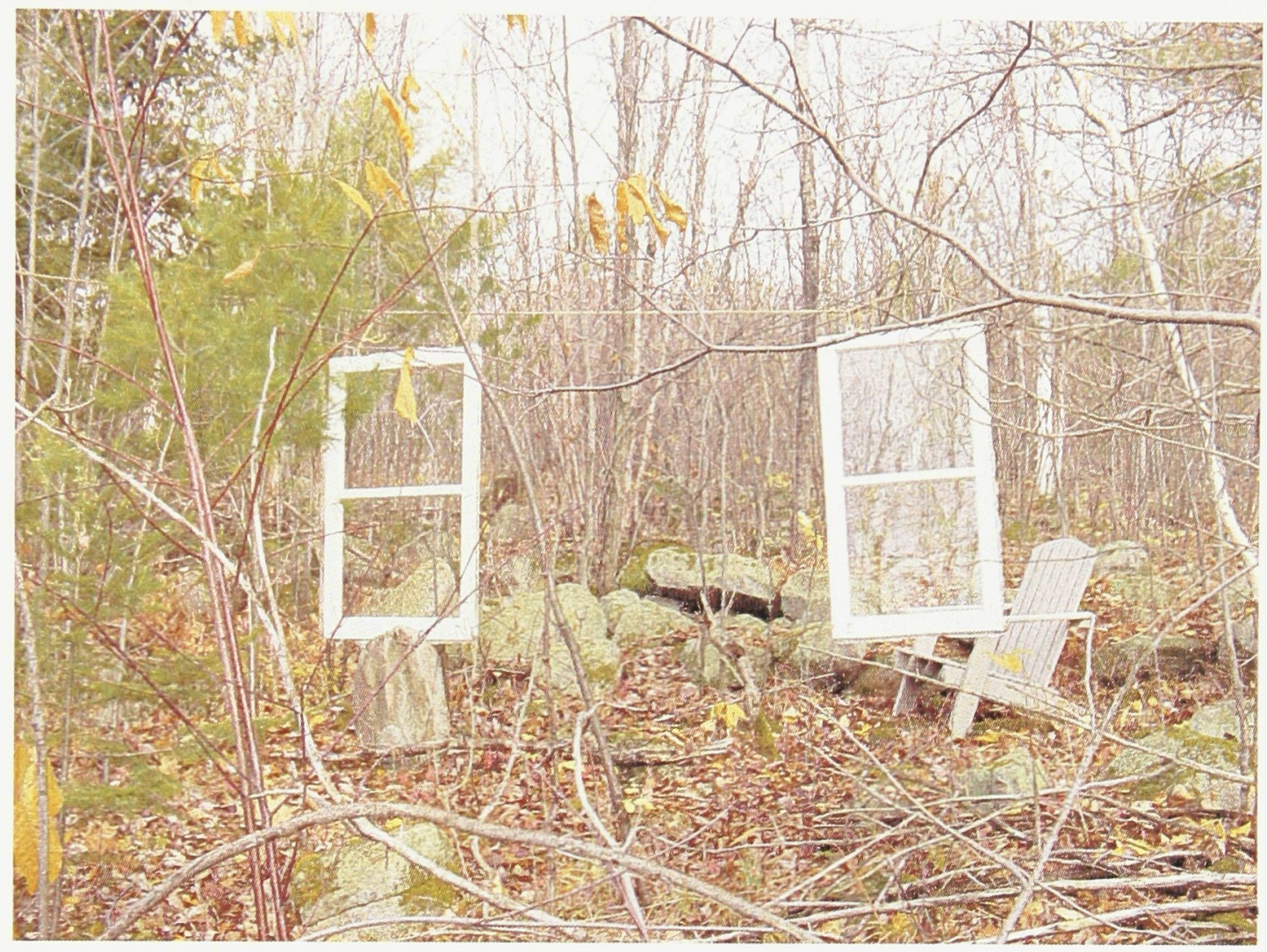

Figure 50 - Installation

The following installations dealt more with the site itself. From the studies of the ephemeral structures, I decided to build my own horizon device. By taking a culvert (which is a typical object found on a farm) and placing it vertically, its function was re-defined and transformed into a device used to frame the horizon. A hole was cut at my exact eye level so that when standing up I would get an unobstructed view of the horizon. If someone shorter or taller than me entered the culvert they would have to stretch or slouch to view out (Fig. 51, 52). Once constructed, the culvert was moved around the site to frame varying conditions found on the property; field, rock, woodland. (Fig. 53) 


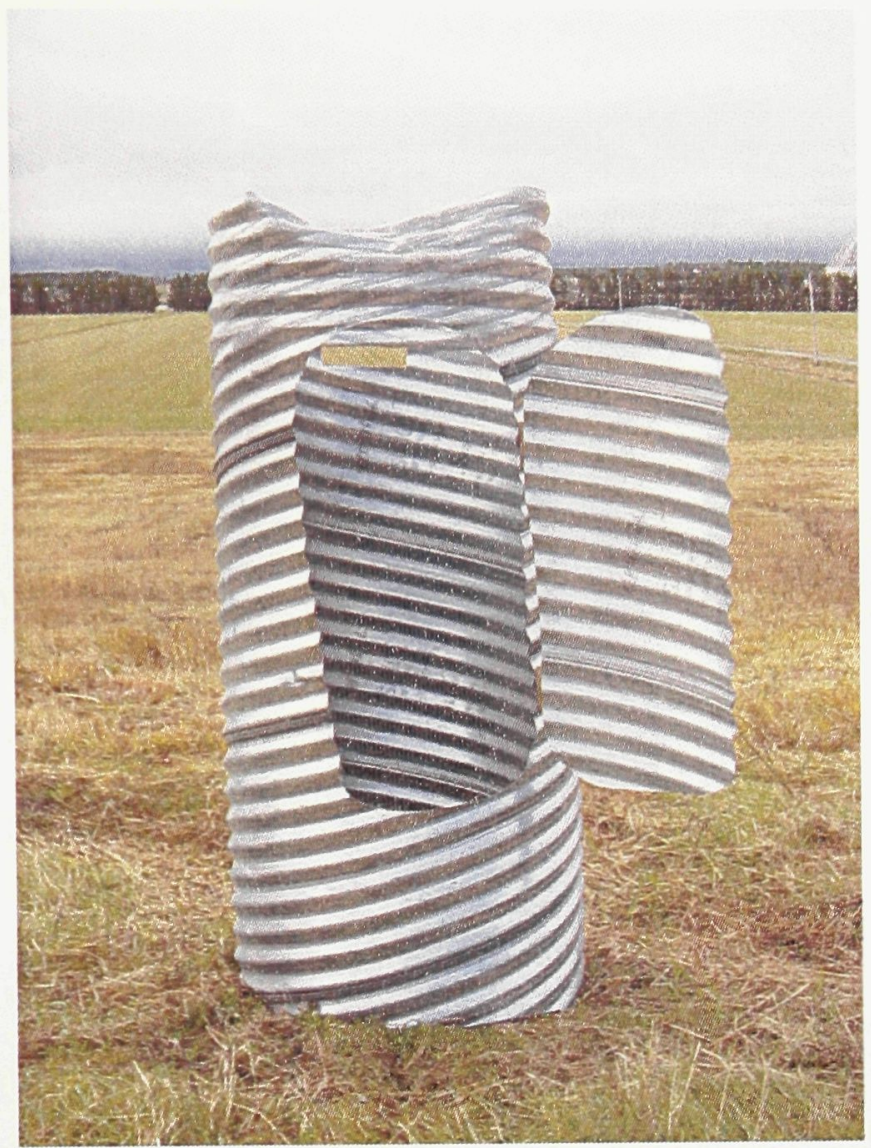

Figure 51 - Installation

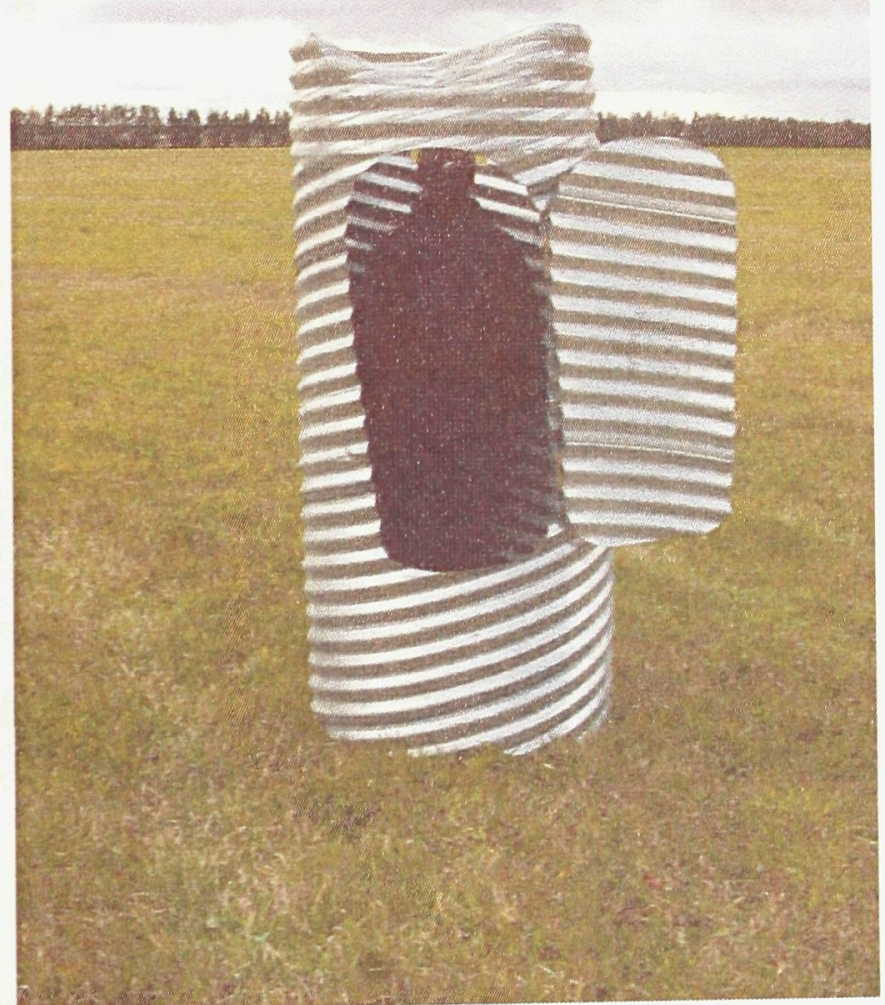

Figure 52 - Installation 

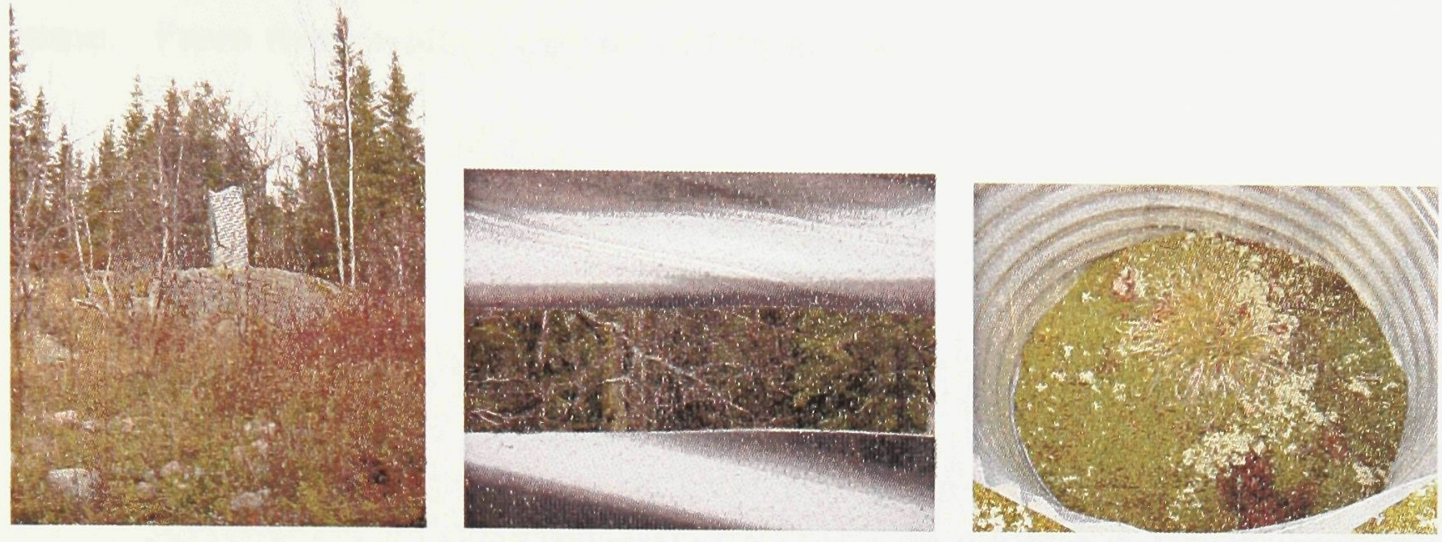

Rock
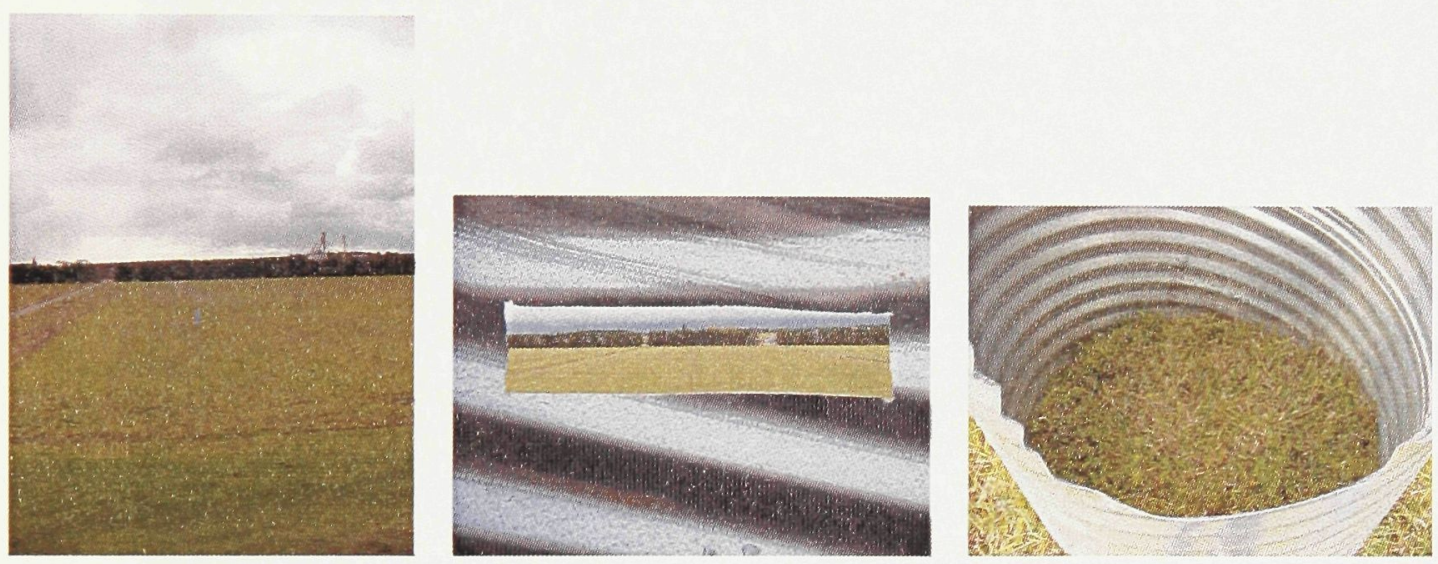

Field
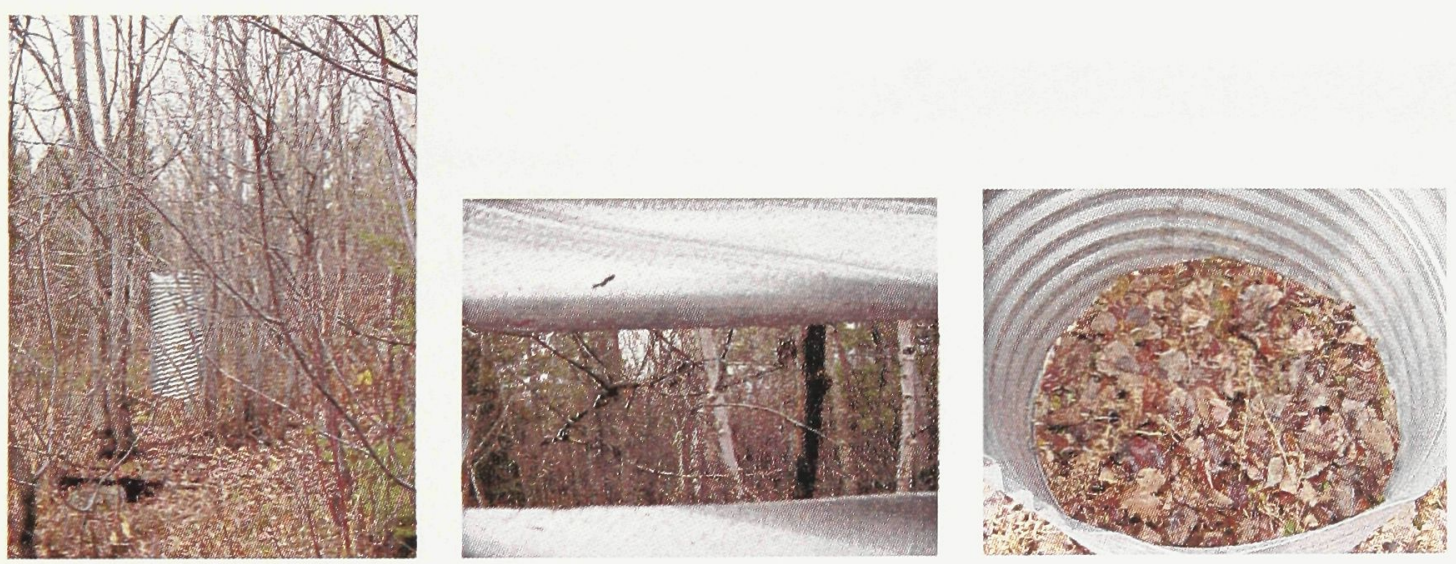

Forest

Figure 53 - Installation at various point on the site

The final installations were burlap walls that would capture snowdrifts and express in the physical form, the changes that occur over time on the site. These 
walls were recorded weekly in order to record the changes occurring over a period of time. From these walls, I can also calculate the exact size of snowdrifts as well as wind directions. (Fig. 54-56)

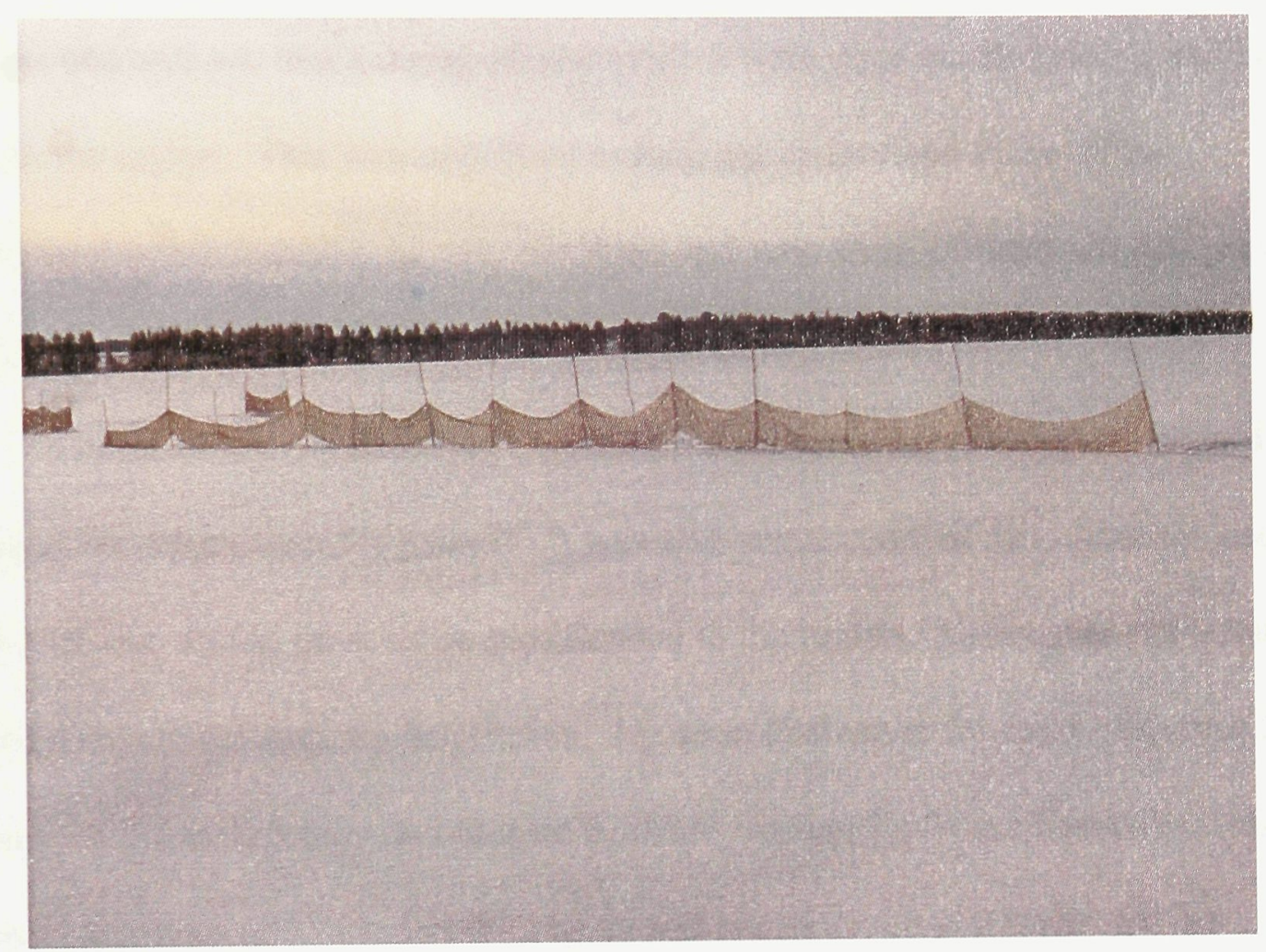

Figure 54 - Installation (snow fences)

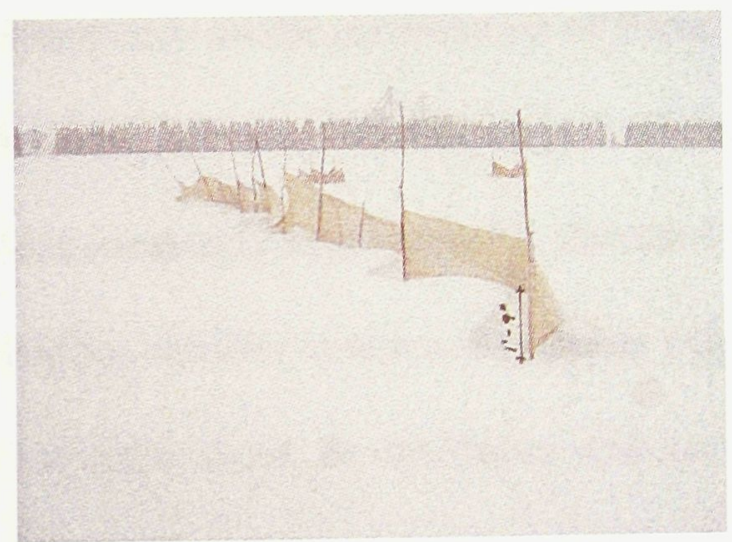

Figure 55 - Installation

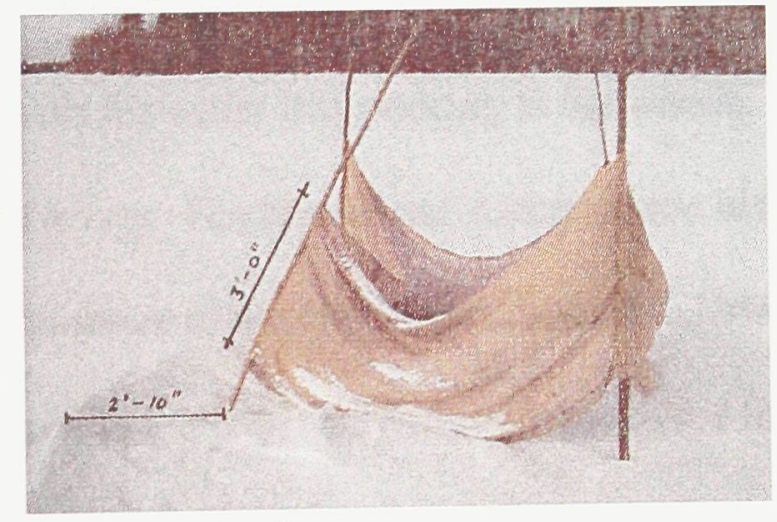

Figure 56 - Installation

In conjunction with the study of the site, I felt it was important to also examine the culture and tradition of the area. It is one thing to integrate the 
environment into a building, it is quite another to integrate culture and tradition into a design project. Therefore, I felt it was important to incorporate both in my final project. This aspect of the research was accomplished by studying the history of the region, as described earlier in the paper. From reading that component of the research, one will see that a series of case studies were done on farmsteads and barns found in the region. This was important to help me understand some of the architectural trends established over the years and why some of them are still present today, while others are no longer deemed important.

In order to test my dwelling I would need a client. More could be learned by designing for others than for oneself. It was also suggested that this character need not be real, but should have some significance to the region. Hence, the character of Médéric Boileau became my inspiration. Médéric Boileau is the main character from the play "La vie et le temps de Médéric Boileau” written by André Paiement. André Paiement was born and raised in the region and his plays are comments on the characteristics and hardships of the area. "La vie et le temps de Médéric Boileau" is a commentary on the assimilation of French Northern communities. The main character, Médéric, is a lumberjack who spends his entire life working in the woods, while constantly expressing his distrust for the city. His best friend Aldège, upon his wedding, decides to leave the lumber camp to move to the city. Later, when Médéric is too old to work, he decides to visit his friend in the city, and finds him paralysed in a wheelchair unable to speak. Aldège dies shortly after his arrival. The play makes a statement for a return to the past, or more so for the way of life that was present before technological advancements. This particular play and character capture the 
essence of the culture of the area very well. Even the language in which it is written is the dialect of the region. Having read the play thirty years after it was written I could still pick up on some insinuations, which are distinct only to this area.

As one method of integrating culture in the design process, the characteristics of Médéric will be embodied in a house design. This will allow a link to be created between the architecture and the culture of the region.

The actual design project began with a series of sketches to determine the characteristics examined. Whether it is site orientation, water, sun, wind, etc., these were drawn in small sketches so that I could determine which component would take precedence over the others. (Fig. 57-62)

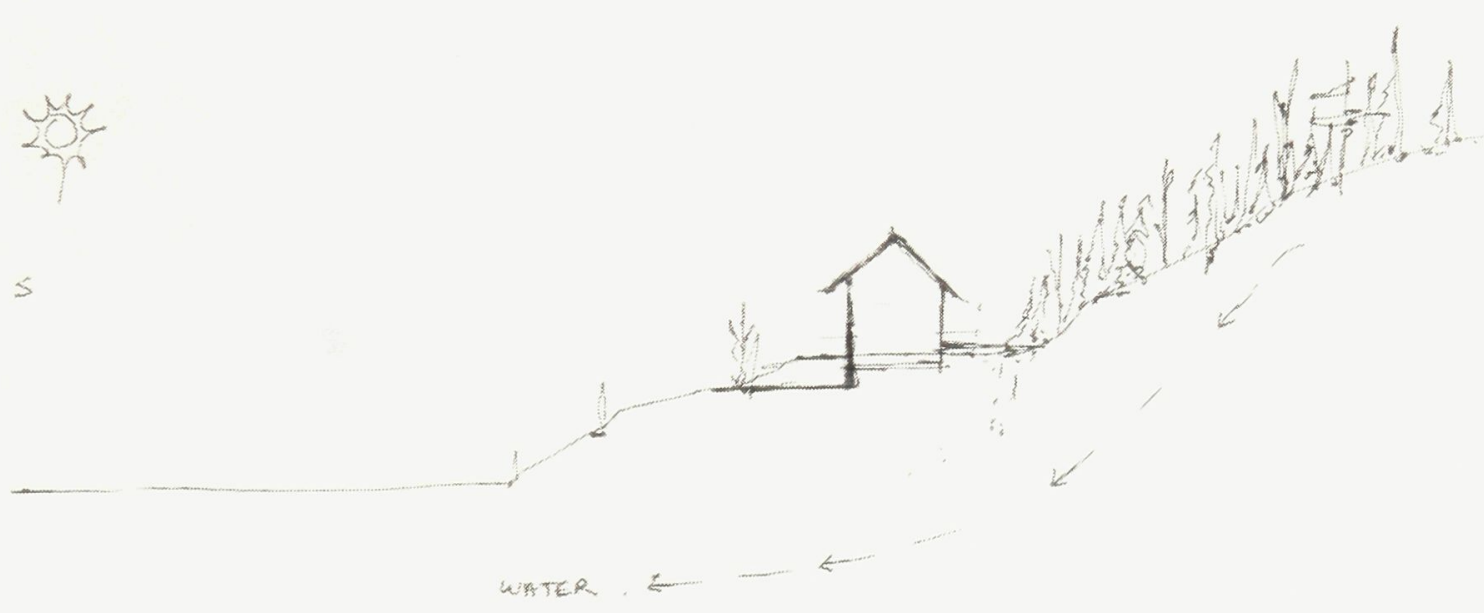

Figure 57 - Sectional sketch 


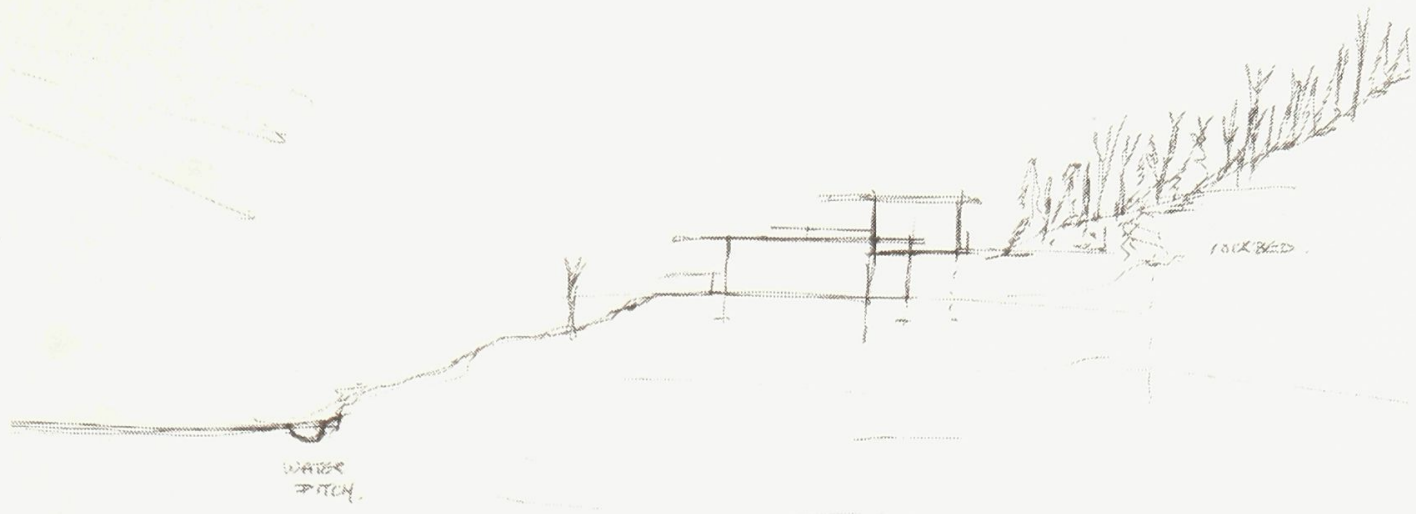

GROWN WATE? (WHAES)

Figure 58 - Sectional sketch

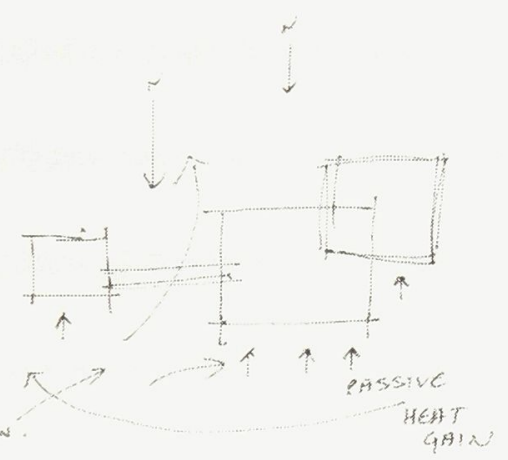

$-2$

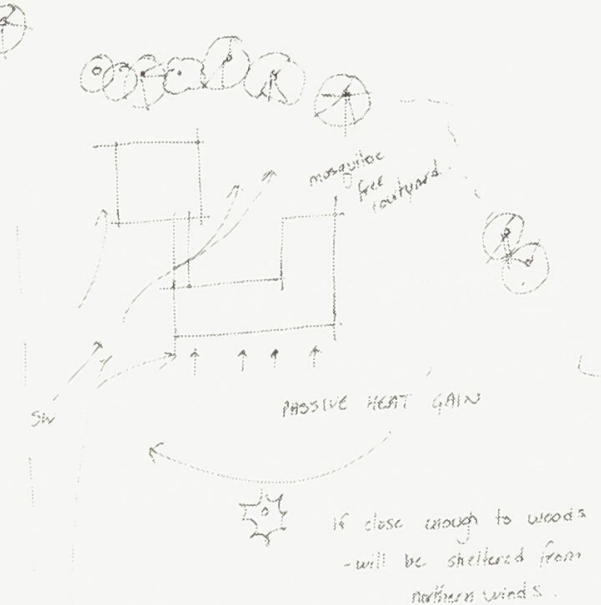

Figure 59 - Sketch (plans)

Figure 60- Sketch (plans) 


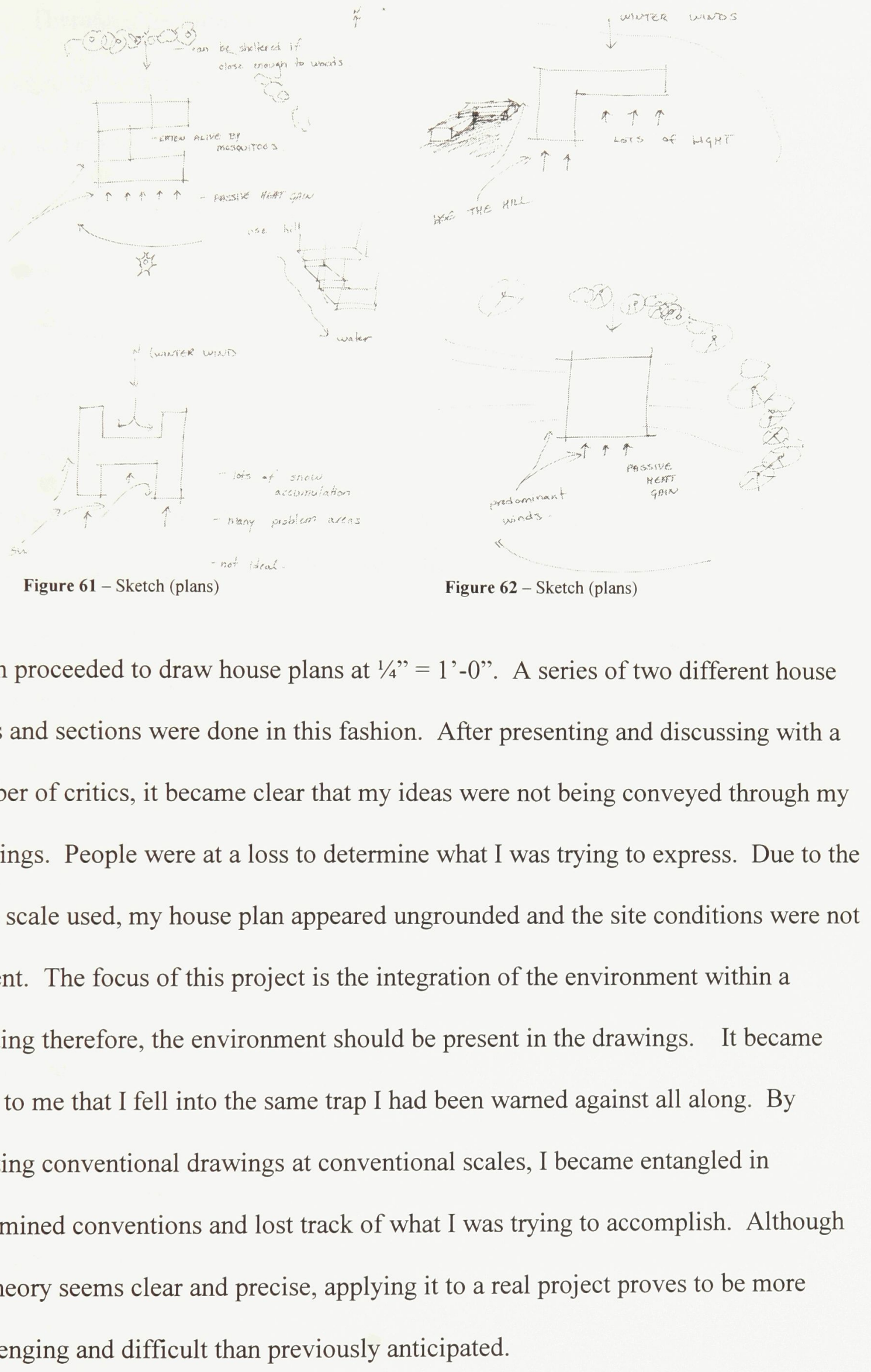


Therefore, by learning from my mistakes, a new approach was undertaken for the design. It became evident that the components I wanted to address, had to be clearly defined before I could present them to an audience. Hence a series of vignettes were created to elaborate such components.

\section{Responses}

By examining the vernacular architecture of Verner it became apparent that the natural environment was utilized to facilitate and accommodate certain needs. These conditions are what I like to refer as the "freebees". By "freebees" I am referring to conditions, which occur naturally in the environment, which can be utilized to enhance an architectural design with no added extra cost, i.e. orientation, wind, light, etc. In order to determine all the "freebees" available I chose to examine the site by season, thus narrowing my research into smaller manageable components.

During the winter months the "freebees" where determined as follows:

orientation (passive heat gain), wood (heat), wind, light and snow. As for the spring months, its "freebees" where determined as such: water, mosquitoes/black flies and a greenhouse (garden). By examining the summer months the "freebees" observed where: wind, mosquitoes, a garden, and heat. Finally, the fall "freebees" where determined to be wood and water. (Fig. 64-67)

Based upon this knowledge, four models (Fig. 63) were constructed as an attempt to incorporate as many "freebees" as possible for each season, keeping in mind that it would be impossible to incorporate all of them in one single scheme. 


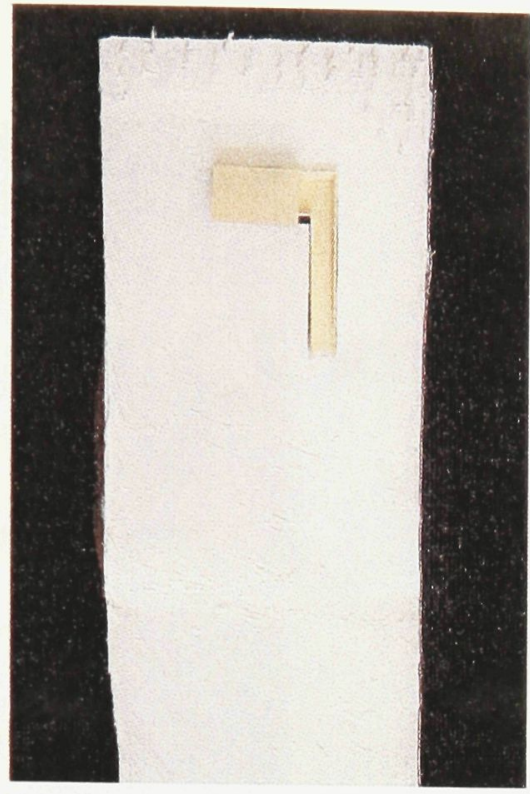

Winter model

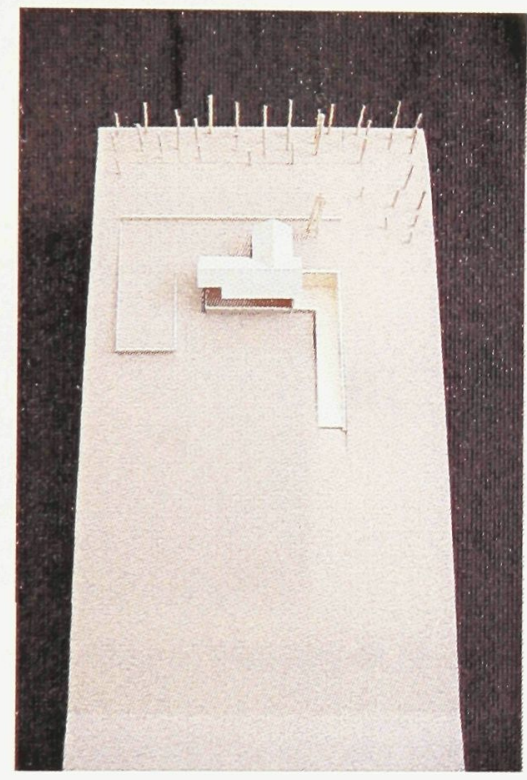

Summer model

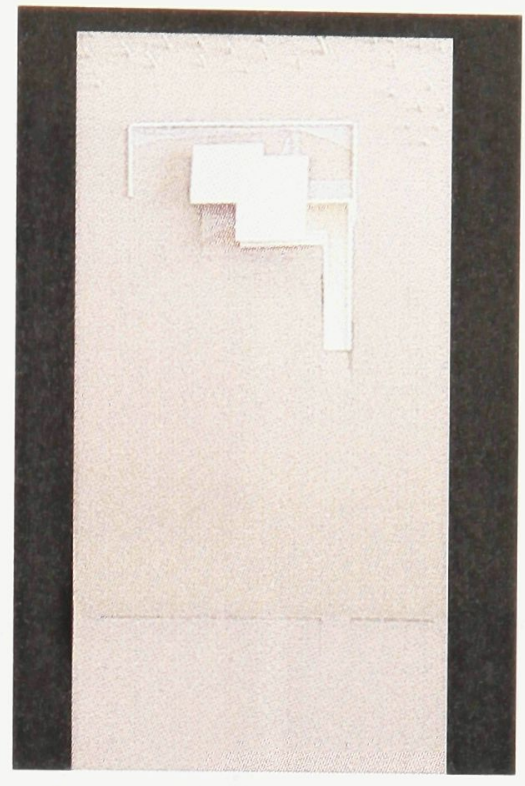

Spring Model

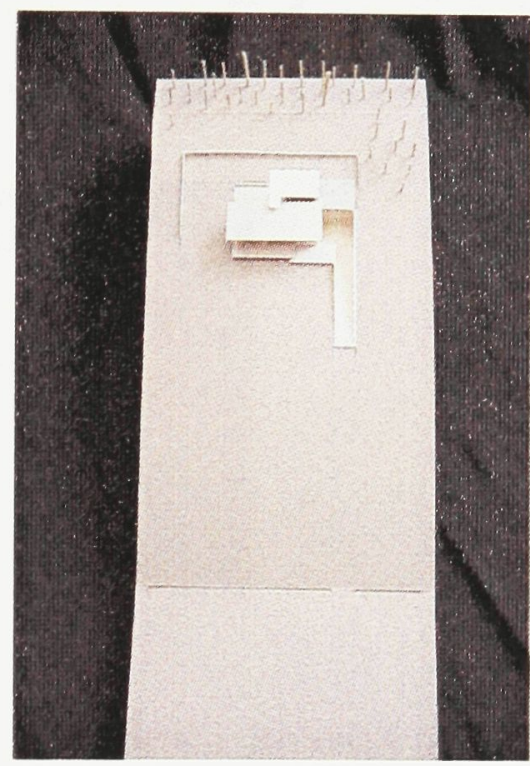

Fall model

Figure 63 - Conceptual models

Each of these models is explained in further detail in the figures that follow. A short paragraph sums up the findings of each investigation explaining the thought process. 


\section{Winter}
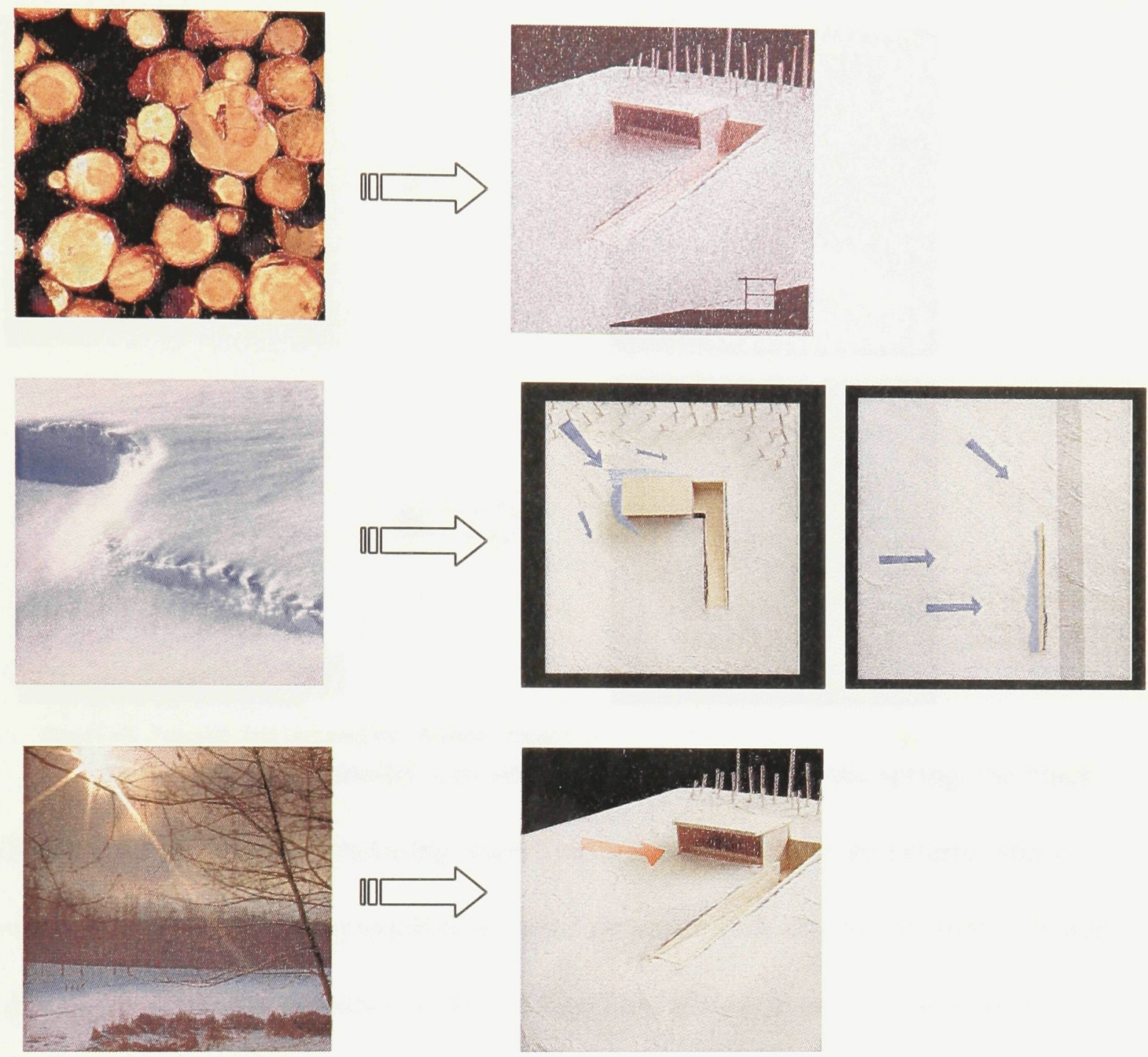

Figure 64 - Diagram demonstrating the "freebees" studied

In terms of the winter model, it was decided that the driveway should be placed on the East side of the building. This would eliminate snowdrifts from accumulating in the driveway, minimizing the amount snow removal. It was also decided that the structure could be heated via a wood stove but since the dwelling is partially buried, some heat gain would be obtained through the earth. By placing the windows on the South facade some passive heat gain could also take place. The North wall could be constructed of a $2^{\prime}-0$ " thick stonewall on which glass could be placed, retaining the heat. The heat could then be vented out when needed. 


\section{Spring}
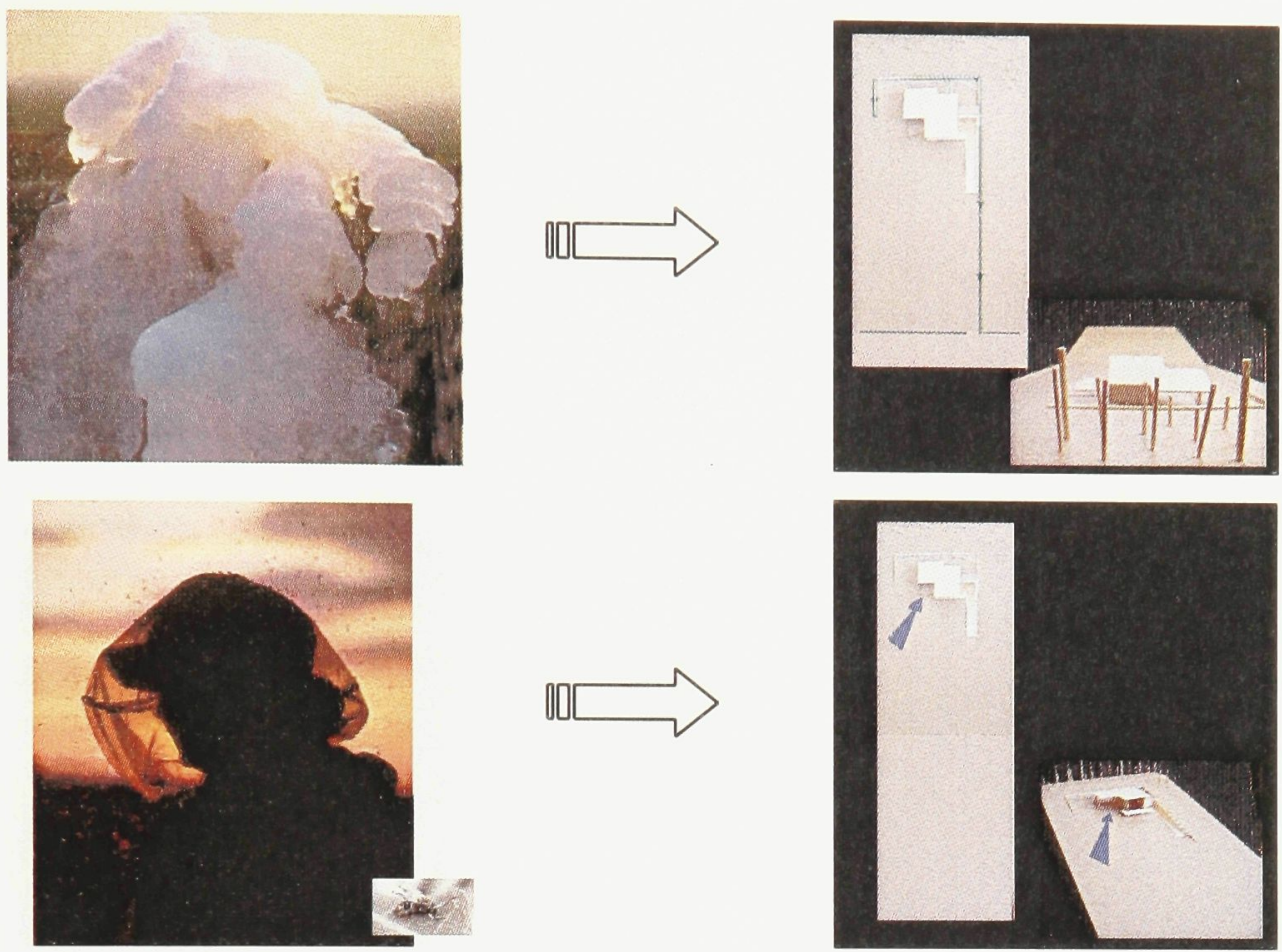

Figure 65 - Diagram demonstrating the "freebees" studied

As for the spring model it mostly focused on wind. In the spring, the black

flies are somewhat overwhelming, therefore, I wanted to create an exterior space,

which was located in the predominant wind direction ( $\mathrm{SW}$ during this time). It was also decided that the greenhouse should face South/West in order to achieve a maximum amount of sunlight and be in close proximity to the garden (on the West side of the house). The greenhouse would allow for a wider variety of vegetables and plants to be planted before the summer months, which are often too short for proper harvest. The greenhouse could also act as a heat sink, providing the dwelling with an alternative heat source to the wood stove. Water was also taken into consideration in this scheme. Since the site is on a hillside, the water flows South. The landscape around the dwelling was designed to deter this water from accumulating around the house. It was re-routed to ensure that it could be collected in underground cisterns, which could then be used for watering the greenhouse and the garden. 


\section{Summer}
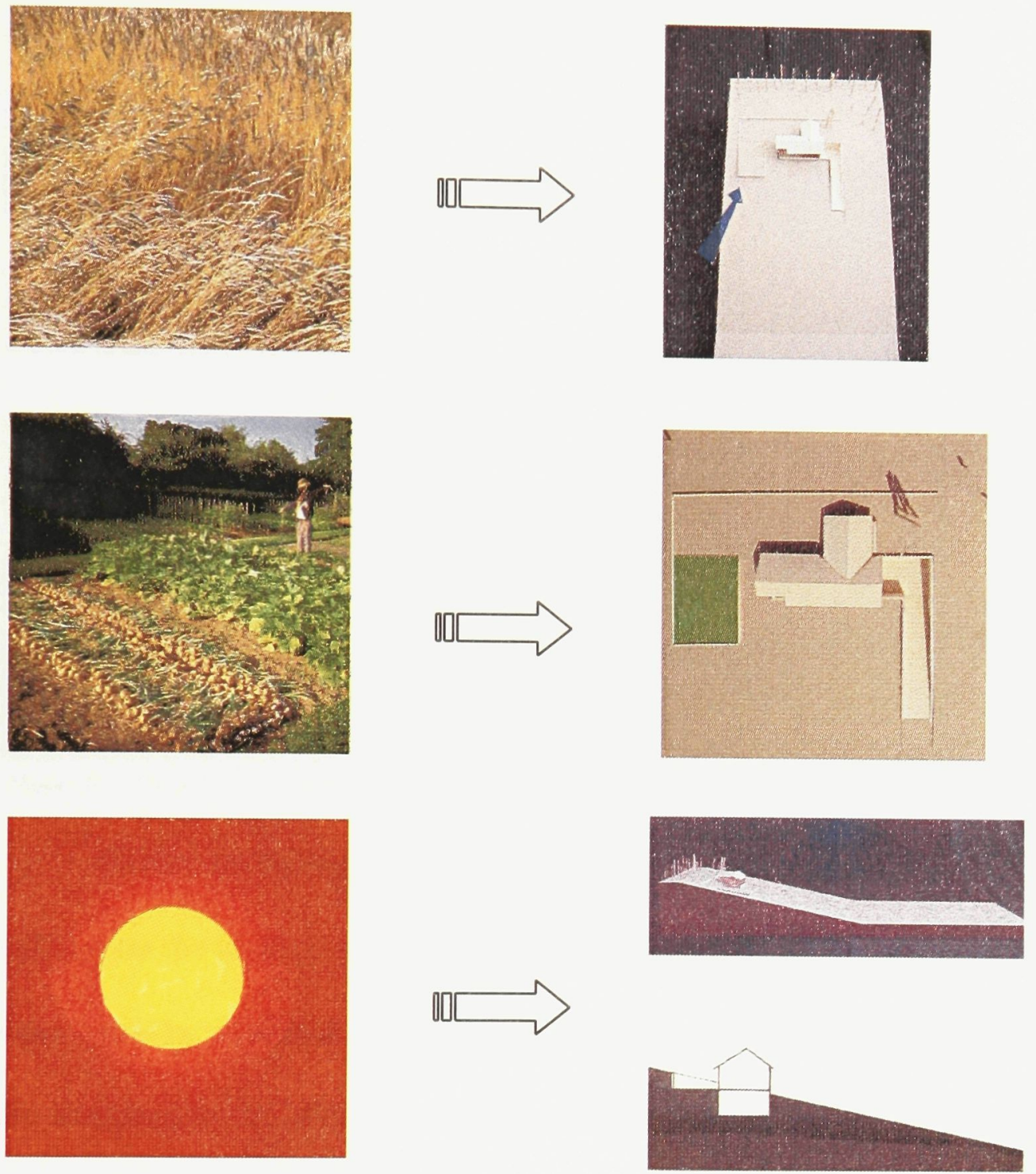

Figure 66- Diagram demonstrating the "freebees" studied

Like the winter model, thermal coolness could be obtained by partially

burying the structure below grade. Since air conditioning is not very common in the area, this approach would help maintain a relatively cool temperature within the house. Placing the garden on the West side of the structure ensures that it is never shadowed by the house. The garden was also placed in the predominant wind direction (SW), eliminating mosquitoes in that area. 


\section{Fall}
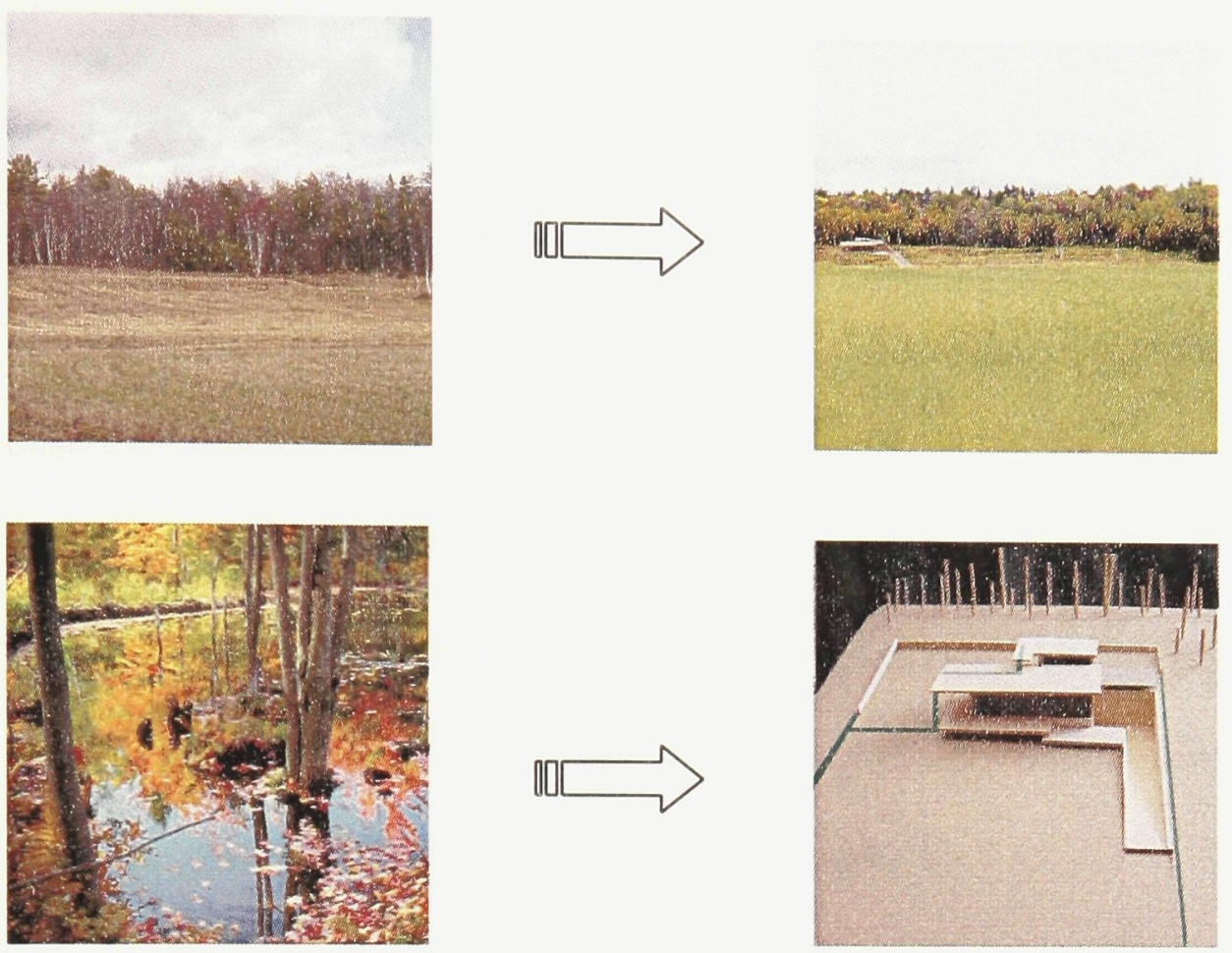

Figure 67 - Diagram demonstrating the "freebees" studied

Finally for the fall model, water was the major concern. The advantage of building on the hillside facilitates the natural drainage of the water south. Again this water could be collected in underground cisterns for future use. The landscape was also designed to facilitate the collection and storage of firewood, which is cut during the fall/winter months.

\section{Final Project}

Since not all "freebees" could be incorporated into one design, some compromises where made. It was decided that the driveway had to remain on the East side to avoid snow accumulations. The driveway was dug into the hillside, allowing the car to park in the basement. This would allow for all the dirt (brought in with the vehicle) to remain on the basement level. By placing the garage below grade, it would not be seen from the highway. This is where the character, Médéric 
Boileau comes into play. The character's endeavour was to retain the past and to advocate that we include everything we need from nature. Hence the principal behind the character's ideas will be incorporated in the scheme's design.

As a tool to help integrate the character even further in the scheme, the project was thought of as a set of layers or clothing providing various degrees of protection from the elements at various locations in the house and in the landscape. By creating a kit of parts, (Fig. 68) which, deal with environmental conditions such as wind, water, snow, etc. each situation could be addressed individually. Hence, the design scheme was based around the notion of self-sufficiency while retaining some characteristics of the culture of the area. (Fig. 69-71) 

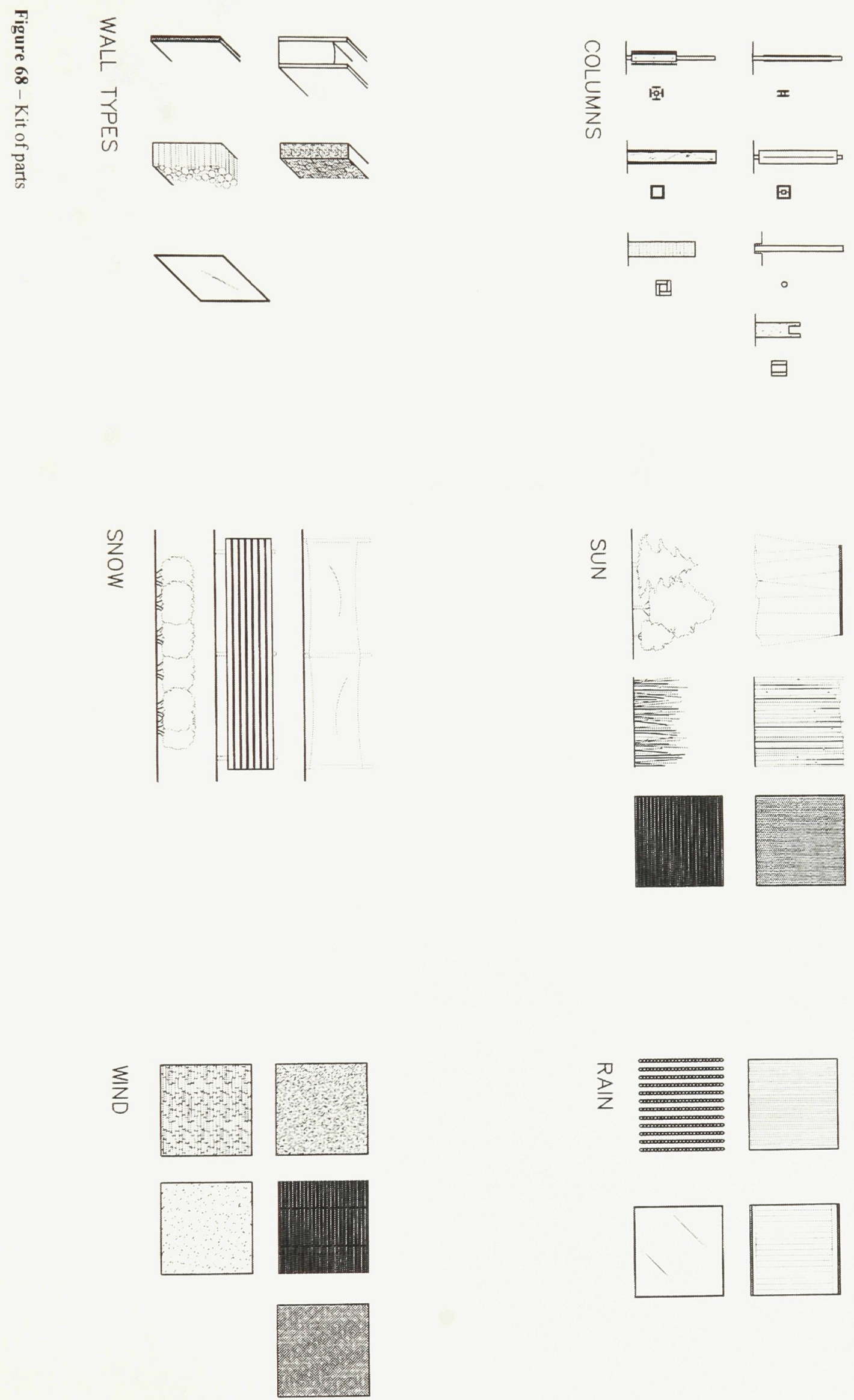

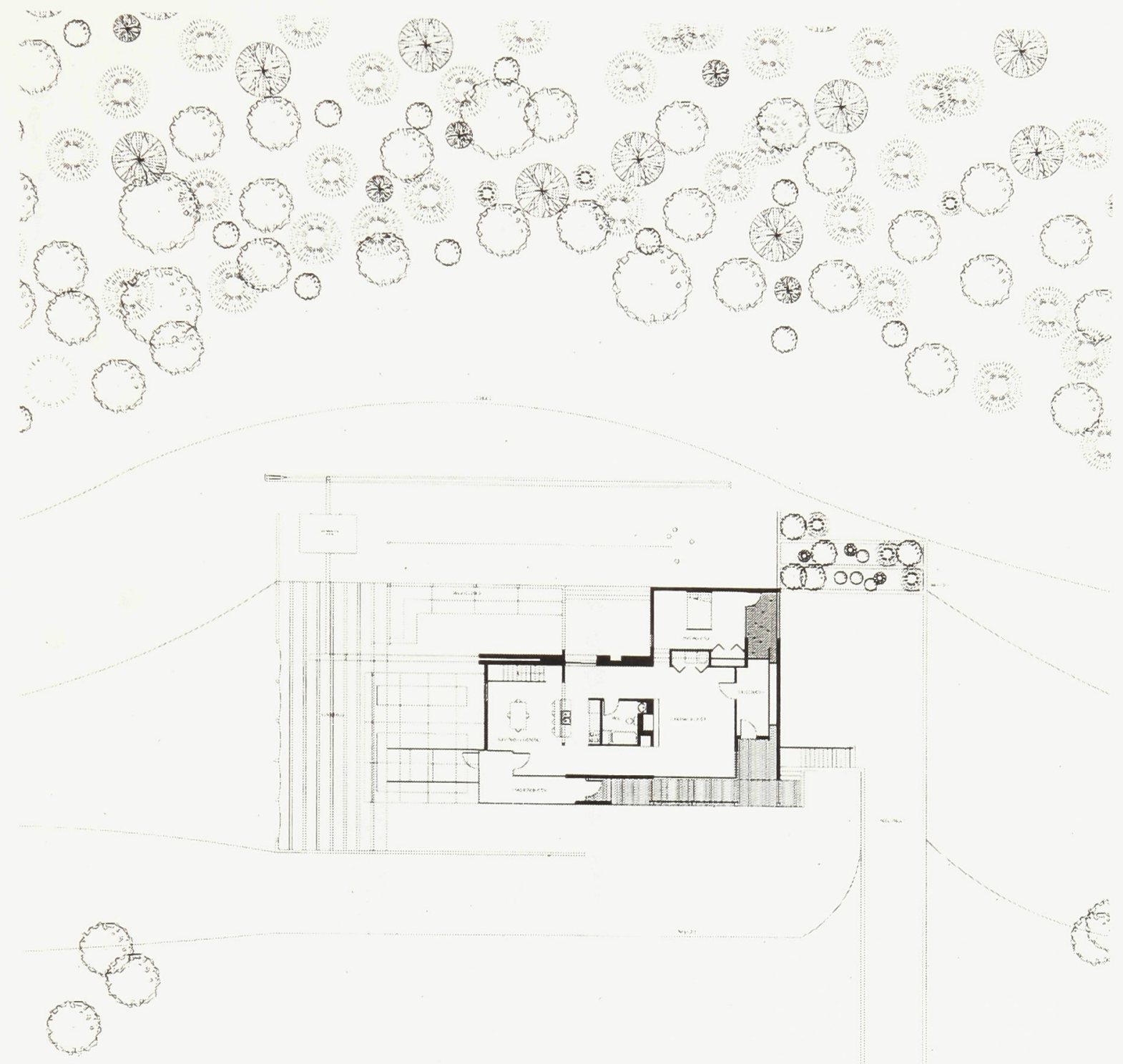


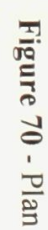
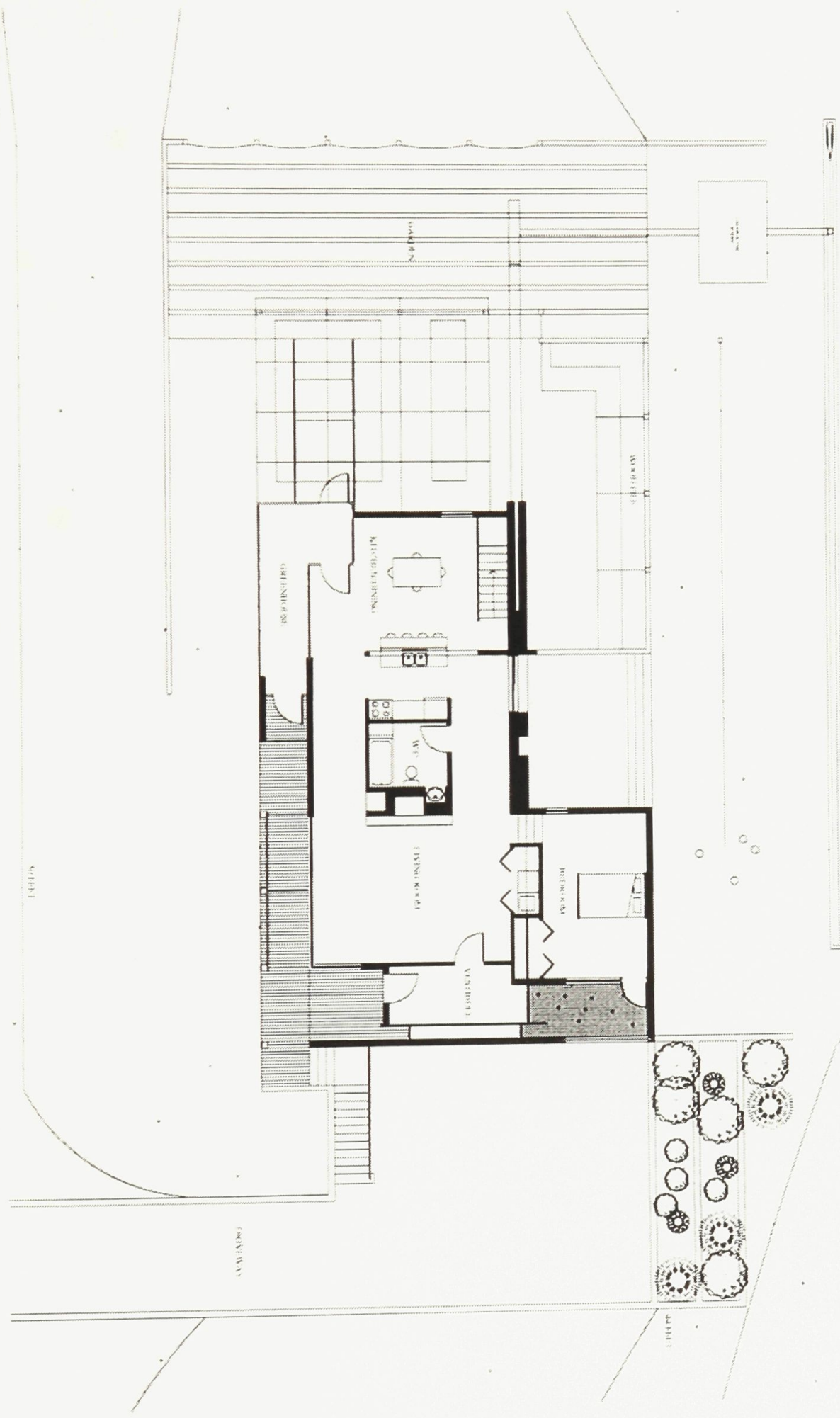

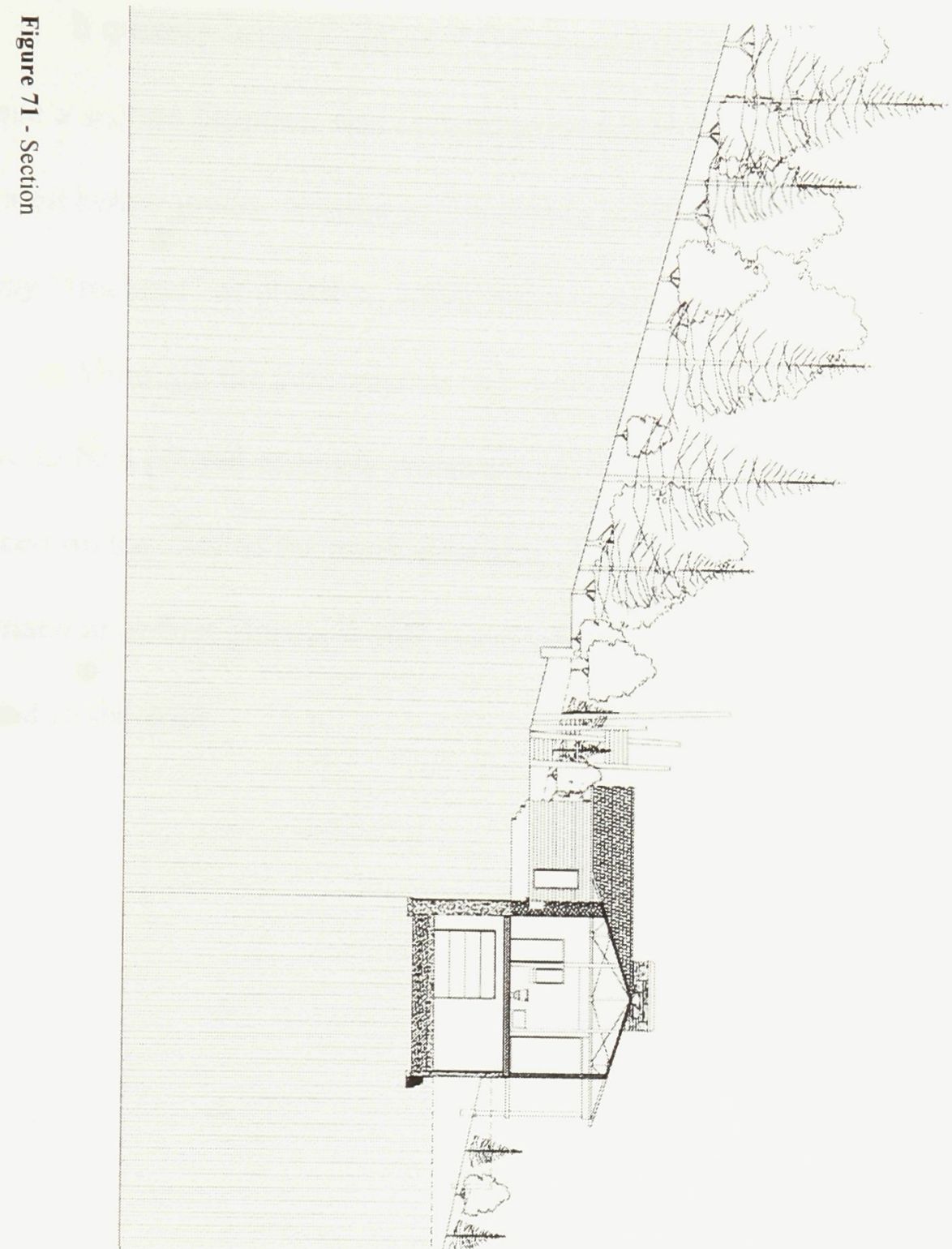
It quickly became apparent that more than one solution could be achieved, hence a second proposal was conceived in which the majority of the structure is located below grade. Similar to the previous scheme, this proposal incorporated as many "freebees" as possible, while also incorporating the character. (Fig. 72-74) Although the first scheme was wood construction, the second scheme would have to be a poured concrete construction. This would allow for the garden to be placed on the roof of the main structure. Even thought this scheme might not appear vernacular at first glance, it still incorporates many ideas present in vernacular models found in the area. 


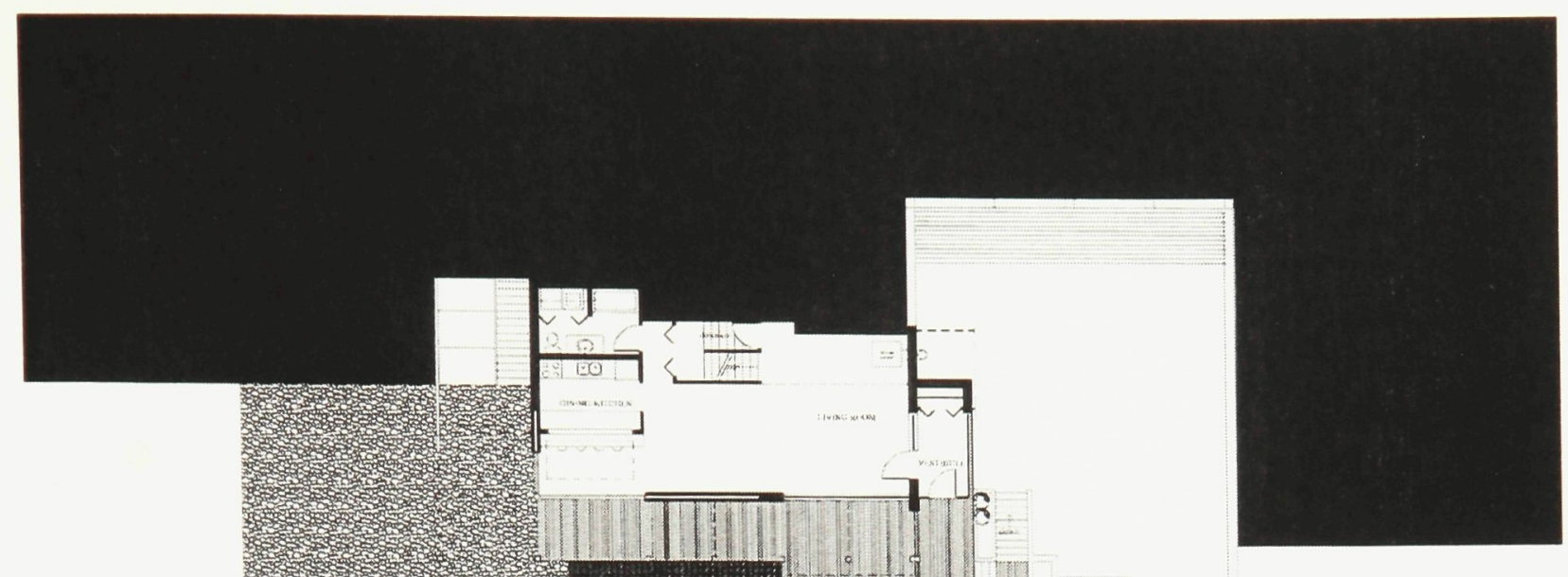

Figure 72 - Plan 

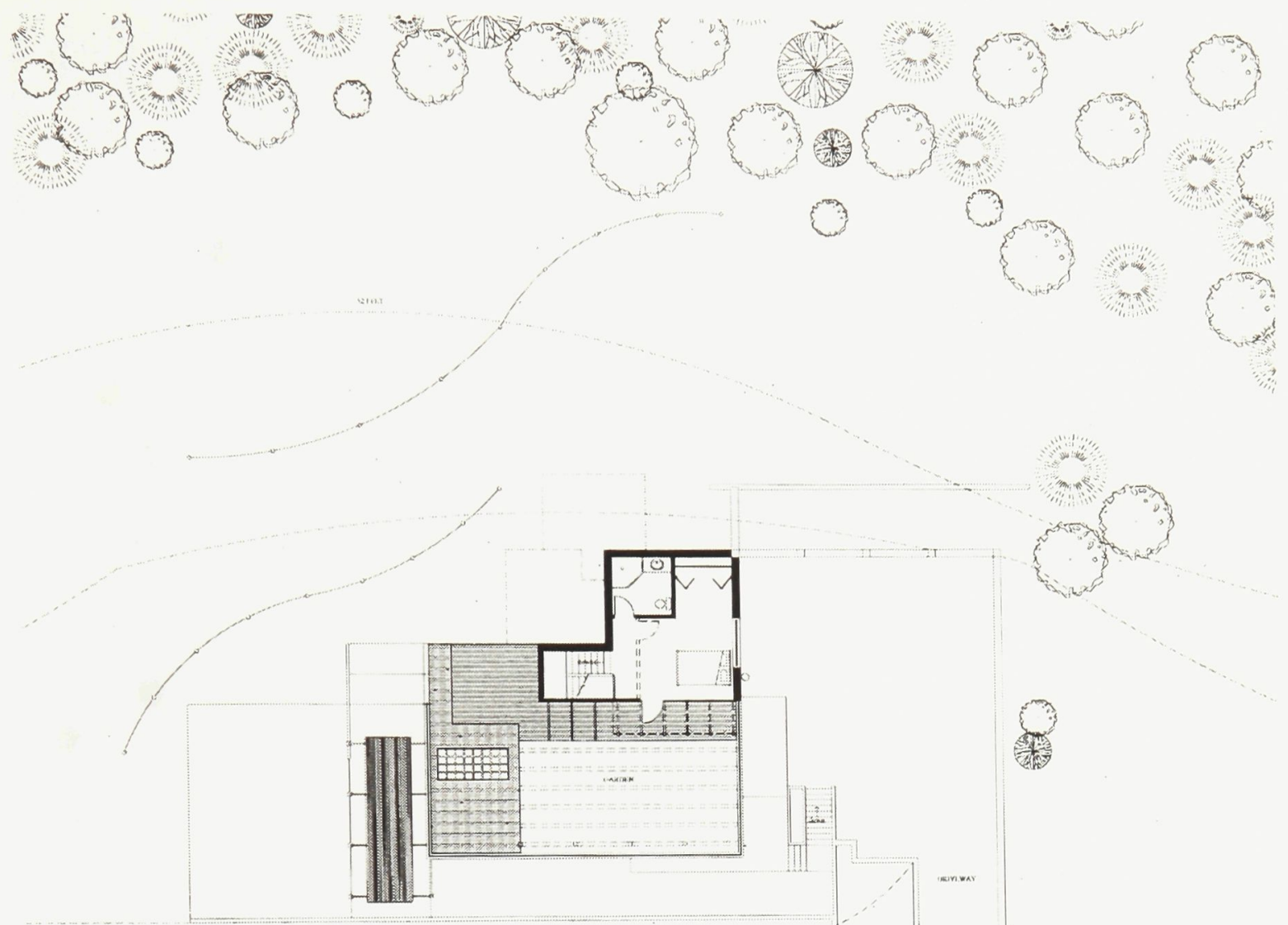

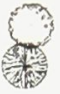




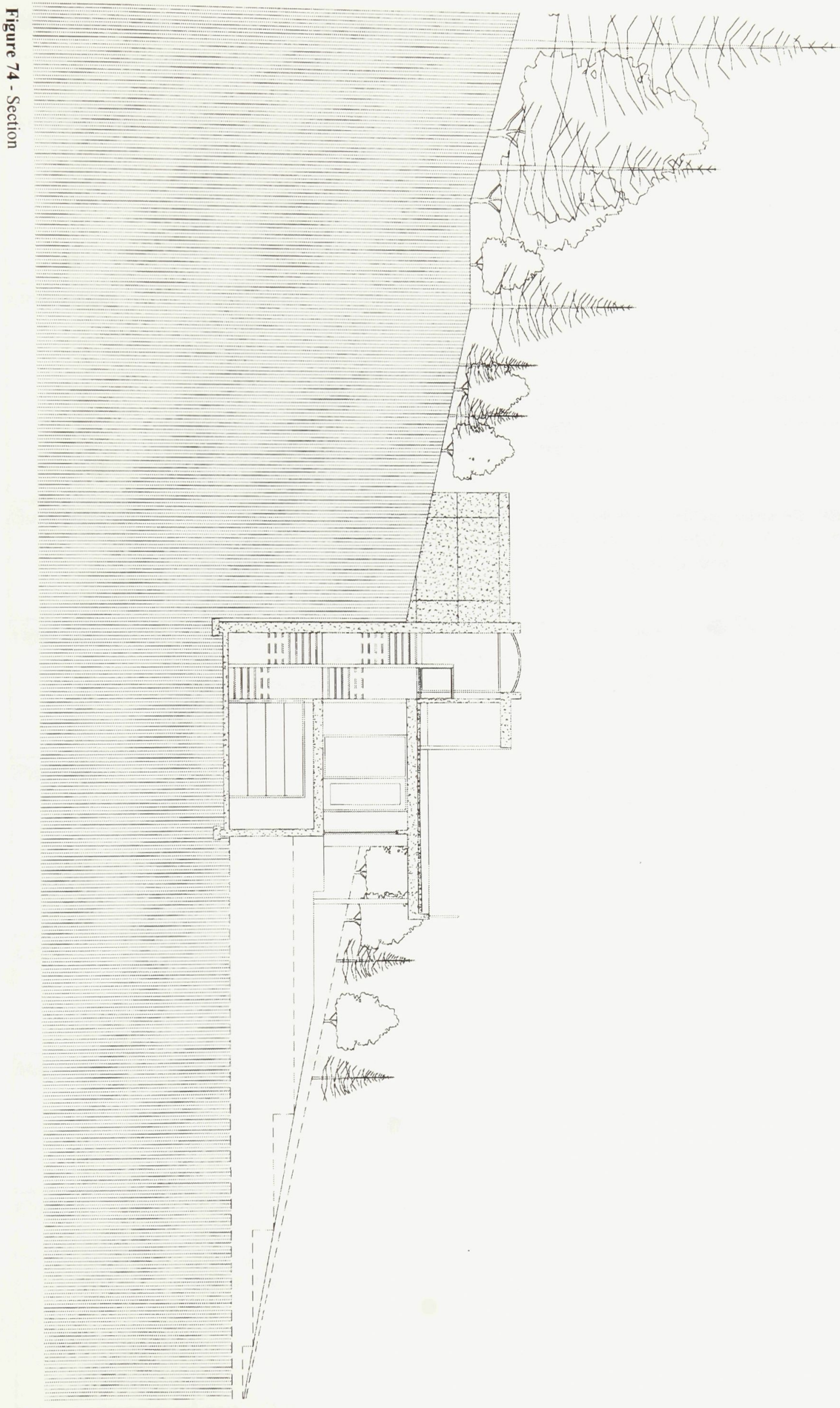


Table 2 - Matrix summarizing the components addressed for the two proposed dwellings

\begin{tabular}{|c|c|c|}
\hline & Scheme 1 & Scheme 2 \\
\hline Wind/Ventilation & $\begin{array}{l}\text { Wind was utilized to deter the } \\
\text { accumulation of black flies. It was } \\
\text { also utilized to create snowdrifts at } \\
\text { specific areas while leaving other } \\
\text { areas like the driveway clear during } \\
\text { the winter months. }\end{array}$ & $\begin{array}{l}\text { Wind was utilized to deter the } \\
\text { accumulation of black flies. It was } \\
\text { also utilized to create snowdrifts at } \\
\text { specific areas while leaving other } \\
\text { areas like the driveway clear during } \\
\text { the winter months. }\end{array}$ \\
\hline Orientation & $\begin{array}{l}\text { Orientated to utilize the wind, sun, } \\
\text { and site. The exterior spaces are } \\
\text { located on the SW side of the } \\
\text { building to utilize predominant } \\
\text { winds. The building is built into the } \\
\text { hillside to obtain passive heat gain } \\
\text { and facilitate the flow of water. } \\
\text { Door faces South. }\end{array}$ & $\begin{array}{l}\text { Orientated to utilize the wind, sun, } \\
\text { and site. The exterior spaces are } \\
\text { located on the SW side of the building } \\
\text { to utilize predominant winds. The } \\
\text { building is built into the hillside to } \\
\text { obtain passive heat gain and facilitate } \\
\text { the flow of water. }\end{array}$ \\
\hline Sun/ Solar Gain & $\begin{array}{l}\text { Orientated to obtain passive heat } \\
\text { gain, with the majority of the } \\
\text { windows on the South facade. }\end{array}$ & $\begin{array}{l}\text { Orientated to obtain passive heat } \\
\text { gain, with the majority of the windows } \\
\text { on the South facade. }\end{array}$ \\
\hline Heat Distribution & $\begin{array}{l}\text { The greenhouse acts as a heat } \\
\text { sink. There is a wood fireplace as } \\
\text { an alternative heat source. Passive } \\
\text { heat gain. }\end{array}$ & $\begin{array}{l}\text { Thermal heat gain, thermal coolness } \\
\text { obtained from placing most of the } \\
\text { structure below grade. }\end{array}$ \\
\hline Planning & $\begin{array}{l}\text { Located near the forest to obtain } \\
\text { protection from the North winds } \\
\text { (winter). Built into the hillside to } \\
\text { obtain thermal heat gain. Also built } \\
\text { into the hillside to facilitate drainage } \\
\text { of water. }\end{array}$ & $\begin{array}{l}\text { Located near the forest to obtain } \\
\text { protection from the North winds } \\
\text { (winter). Built into the hillside to } \\
\text { obtain thermal heat gain. Also built } \\
\text { into the hillside to facilitate drainage } \\
\text { of water. Roof garden. }\end{array}$ \\
\hline Light & $\begin{array}{l}\text { Most windows face the South } \\
\text { facade, while others face the East } \\
\text { side (bedroom) and West side. }\end{array}$ & $\begin{array}{l}\text { Most windows face the South facade. } \\
\text { The bedroom is located above grade } \\
\text { to let more light enter the room. }\end{array}$ \\
\hline Materials & $\begin{array}{l}\text { Local materials- concrete blocks for } \\
\text { the foundations, no. } 2 \text { grade spruce } \\
\text { for the framing, stone finish, wood } \\
\text { siding, glass, and metal shingles. }\end{array}$ & $\begin{array}{l}\text { Local materials- poured concrete } \\
\text { structure, and glass. }\end{array}$ \\
\hline Culture & $\begin{array}{l}\text { Follows the vernacular of the area - } \\
\text { pitch roof, wood construction. } \\
\text { Construction method common to } \\
\text { the area }\end{array}$ & $\begin{array}{l}\text { Does not follow the vernacular of the } \\
\text { area - flat roof, concrete construction } \\
\text { for a dwelling. Would need } \\
\text { specialized labour to pour the } \\
\text { structure. Yet it addresses the same } \\
\text { issues as the same scheme but with a } \\
\text { different construction process. }\end{array}$ \\
\hline
\end{tabular}




\begin{tabular}{|l|l||l|}
\hline Seasonal & $\begin{array}{l}\text { Designed to close itself during the } \\
\text { winter months, and open up to } \\
\text { create int./ext. spaces during the } \\
\text { summer months. }\end{array}$ & $\begin{array}{l}\text { Designed to close itself during the } \\
\text { winter months, and open up to create } \\
\text { int./ext. spaces during the summer } \\
\text { months. }\end{array}$ \\
\hline
\end{tabular}

\section{Conclusion}

"Architects must raise expectations by showing through discussion and by example that a building can and should do more than keep out wind and snow: by showing that planned space can and should not just support human activity but enhance it in ways not previously considered possible; by showing that the research performed between the decision to build and the start of design is a vital learning experience for owner, user, and architect with direct consequences for the success of the finished building; by showing that the work of clarifying the purpose and content of the project can be stimulating, enjoyable and, as things start to make complete sense, reassuring; by showing that a successful design evokes in people the agreeable thought that 'human intelligence was at work here for our benefit. ${ }^{, 49}$

It is clear that technology need not dictate how we utilize nature, but rather it can be used in harmony with nature, and with this understanding our architectural endeavour can become more meaningful for a culture living deeply embedded in the environment. Through the study of past architectural models, one comes to understand the complexity and integrity that such design held. What was once known as common sense has now become known as "sustainable" or "ecological" design. Past knowledge is being replaced with gadgets and technological advancements that serve no real function, but distance ourselves from an environmental based architecture. 
To answer the question being posed: Has the balance between preconceived building processes and an environmental based architecture been pulled out of sync by an over-consumption of a singular typology? The answer would appear to be yes. Through technological ingenuity, a new method of construction has been established in which you need more products to fulfill more tasks. Little consideration for the site's attributes are taken into consideration, yet all the latest technologies such as HVAC systems, air conditioning, and UV coated windows are deemed to be the most important. Suburban houses are being erected in huge developments, where homogeneity reigns and wastefulness is praised. Yet, nature remains, and its lessons are still there for those willing to pay attention. The time has come to construct buildings, which have a northern soul, rather than copying a southern philosophy. 


\section{Bibliography}

Arthur, Eric and Dudley Witney. The Barn: A Vanishing Landmark in North America. Toronto: M.F. Feheley Arts, 1972.

Baniassad, Essy, ed. Architecture Canada 1999: The Governor General's Medals for Archtiecture. Halifax: Tuns Press, 2000.

Baillargeon, Diane and Denis Plante. "Quand l'Université créait des poules et des melons: l'Institut agricole d'Oka a connu sept décennies de prospérité." Iforum 37.9 (2002) 28 Oct. 2004 $<\mathrm{http}: / / \mathrm{www}$.iforum.umontreal.ca/Forum/ArchivesForum/20022003/021028/article1604.htm>

Beaudry, Gérald, et al. Verner: cent ans d'histoire à raconter... Verner: Bureau du canton de Caldwell, 1995.

N.A. "Winter Gardens." Canadian Architect 46.12 (2001): 30-31.

Documents in Canadian Architecture. Barry Johns Architects. Halifax: Tuns Press, 2000 .

Frye, Northrop. Toronto Globe and Mail. 18 October 1977

Grant, George. Lament of a Nation: The Defeat of Canadian Nationalism. Montréal: McGill-Queen's University Press, 2000.

Jackson, Anthony. The Democratization of Canadian Architecture. Halifax: TechPress, 1978.

---. The Future of Canadian Architecture. Halifax: Tech-Press, 1979.

Kapelos, George Thomas. Interpretations of Nature: Contemporary Canadian Architecture, Landscape and Urbanism. Kleinburg: McMichael Canadian Art Collection, 1994.

Kesik, Ted. "Principles of Enclosure." Canadian Architect 47.3 (2002): 34-35.

Lebelle, Wayne F. Sturgeon Falls: 1895-1995. Field: WFL Communications, 1995.

L'institut Agricole d'Oka. Cours d'Agriculture- Tome1. 3rd edition. Québec: Institut Agricole d'Oka, 1948.

Mänty, Jorma and Norman Pressman, ed. Cities Designed For Winter. Helsinki: Building Book Ltd, 1988. 
Reynolds, Stein. Mechanical and Electrical Equipment for Buildings. $9^{\text {th }}$ ed. New York: John Wiley \& Sons, Inc., 2000.

Rudofsky, Bernard. Architecture Without Architects. New York: Doubleday \& Company, Inc., 1964.

Strub, Harold. Bare Poles: Building Design For High Latitudes. Ottawa: Carleton University Press, 1996.

Thibault, Pierre. Projects and Achievements. Québec: Belle Publisher, 1997.

Williams, Raymond. Keywords: A Vocabulary Of Culture And Society. Rev. ed. New York: Oxford University Press, 1983. 